University of Chicago Law School

Chicago Unbound

Journal Articles

Faculty Scholarship

1958

\title{
The Constitution and the the Choice of Law: Governmental Interests and the Judicial Function
}

Brainerd Currie

Follow this and additional works at: https://chicagounbound.uchicago.edu/journal_articles

Part of the Law Commons

\section{Recommended Citation}

Brainerd Currie, "The Constitution and the the Choice of Law: Governmental Interests and the Judicial Function," 26 University of Chicago Law Review 9 (1958).

This Article is brought to you for free and open access by the Faculty Scholarship at Chicago Unbound. It has been accepted for inclusion in Journal Articles by an authorized administrator of Chicago Unbound. For more information, please contact unbound@law.uchicago.edu. 


\title{
THE CONSTITUTION AND THE CHOICE OF LAW: GOVERNMENTAL INTERESTS AND THE JUDICIAL FUNCTION
}

\author{
BRAINERd CORRIE $\dagger$
}

Several intricate questions arise from the different prescriptions that are established in different countries. In our decisions upon this head it is commonly disputed, whether a foreign prescription or that of our own country ought to be the rule. This never ought to be disputed; for every case that comes under our ownlaw, must be decided by that law and not by the law of any other country. When the matter is accurately considered, the debate will be found to turn upon a different point, viz. whether the case in question comes under our prescription. This may often be a doubtful point; because many cases come under the words of a statute, that are not comprehended under its spirit and intendment. ... What only belongs to the present subject, is the effect that ought to be given to foreign prescriptions where our own are not applicable; and the subject thus circumscribed will be found abundantly simple and plain.

Kames, Principles of Equity 283 (1760).

\section{INTRODUCTION}

I

N A SERIES of case studies, ${ }^{1}$ I have advanced some suggestions concerning conflict-of-laws method which may be generalized, at the price of oversimplitication, as follows:

1. Normally, even in cases involving foreign factors, a court should as a matter of course look to the law of the forum as the source of the rule of decision. $^{2}$

2. When it is suggested that the law of a foreign state, rather than the law of the forum, should furnish the rule of decision, the court should first of all determine the governmental policy-perhaps it is helpful to say the social, economic, or administrative policy-which is expressed by the law of the forum. The court should then inquire whether the relationship of the forum state to the case at bar-that is, to the parties, to the transaction, to the subject matter, to the

$\dagger$ Professor of Law, University of Chicago.

1 Married Women's Contracts: A Study in Conflict-of-Laws Method, 25 U. of Chi. L. Rev. 227 (1958); Survival of Actions: Adjudication versus Automation in the Conflict of Laws, 10 Stan. L. Rev. 205 (1958); On the Displacement of the Law of the Forum, 58 Col. L. Rev. 964 (1958).

2 The limitation in the statement of this principle is important. There are situations in which foreign law may be relevant otherwise than as the source of the rule of decision. The argument in this paper is not addressed to such situations. For a fuller consideration of the different purposes for which reference may be made to foreign law, see Currie, On the Displacement of the Law of the Forum, 58 Col. L. Rev. 964 (1958). 
litigation-is such as to bring the case within the scope of the state's governmental concern, and to provide a legitimate basis for the assertion that the state has an interest in the application of its policy in this instance.

3. If necessary, the court should similarly determine the policy expressed in the proffered foreign law, and whether the foreign state has a legitimate interest in the application of that policy to the case at bar.

4. If the court finds that the forum state has no interest in the application of its law and policy, but that the foreign state has such an interest, it should apply the foreign law.

5. If the court finds that the forum state has an interest in the application of its law and policy, it should apply the law of the forum even though the foreign state also has such an interest, and, a fortiori, it should apply the law of the forum if the foreign state has no such interest. ${ }^{3}$

It is probable that the most controversial aspect of this suggested method will be its central reliance on the concept of governmental interest. To some this will seem a repudiation of the basic ideals of conflict-of-laws method: the attainment of uniformity of result and of "justice" between the parties. It is true that the implications of such an approach to problems of the conflict of laws are farreaching and iconoclastic. I have suggested that, in the light of this kind of analysis, some typical choice-of-law problems fall into two classes: (1) false problems and (2) problems which are insoluble by any conceivable conflict-oflaws method. ${ }^{4}$ When one of two states related to a case has a legitimate interest in the application of its law and policy and the other has none, there is no real problem; clearly the law of the interested state should be applied. The appearance of a problem is created by the existence of rules which, often without regard to the interests of the states, designate talismanic "contacts" as determinative of the choice of law. When each of two states related to a case has a legitimate interest in the application of its law and policy, a problem is presented which cannot be rationally solved by any method of conflict of laws-that is to say, by any effort, legislative or judicial, on the part of the states concerned to establish universal choice-of-law rules. In such a context, a choice-of-law rule is simply a device which, typically without explicitly saying so, subordinates the interest of one state to that of the other. A court is ordinarily not warranted in sacrificing interests of its own state for the sake of interstate uniformity of result. A legislature might conceivably do so, though its action would be incongruous. Thus, if

${ }^{3}$ In comparatively rare cases, it may be found that neither state has an interest in the application of its policy, although no other state is concerned. See Currie, Survival of Actions: Adjudication versus Automation in the Conflict of Laws, 10 Stan. L. Rev. 205, 229-32, 244 (1958). In such cases, also, it seems that the law of the forum should ordinarily be applied. See also Currie, On the Displacement of the Law of the Forum, 58 Col. L. Rev. 964, 1017 (1958).

4 See Currie, Married Women's Contracts: A Study in Conflict-of-Laws Method, 25 U. of Chi. L. Rev. 227, 251 (1958); Currie, Survival of Actions: Adjudication versus Automation in the Conflict of Laws, 10 Stan. L. Rev. 205, 239 (1958). 
the states concerned should concurrently, by legislative action, establish the same choice-of-law rule, the result might be likened to an agreement that the policy of the one state or the other should be preferred; and, concededly, diplomatic and political techniques afford possibilities of rational solution which are not afforded by techniques purely jurisprudential. Such an arrangement, however, would share the defects of the interstate agreement as a solution; and prominent among these defects is the discrimination against local, and in favor of foreign, litigants which may result. ${ }^{5}$

The suggested approach will also be distasteful to some because it frankly counsels the pursuit of self-interest-and this in a field in which idealism, altruism, and internationalism have been given conspicuous place. Let me hasten to add that the self-interest which the state is to pursue is only its moderate and legitimate interest, and that for states of the Union this pursuit is importantly limited by provisions of the federal Constitution other than those which will be the principal subject of discussion in this paper: notably, by the Privileges and Immunities Clause ${ }^{6}$ and the Equal Protection Clause. ${ }^{7}$ The counsel that each state should pursue its moderate and legitimate interest proceeds not from any love of selfishness and provincialism, nor from any disregard of the values of uniformity as an ideal, but from the need to seek a rational method for dealing with conflict-of-laws problems. Traditional doctrine often requires a state to sacrifice its own interest even though the interest of no other state is thereby advanced. In cases of truly conflicting interests, traditional doctrine requires a state to sacrifice its interest consistently or haphazardly, depending on the extent to which the critical "contact" happens to coincide with factors relevant to the policies involved; and the requirement is typically made without explicit

${ }^{5}$ See Currie, Married Women's Contracts: A Study in Conflict-of-Laws Method, 25 U. of Chi. L. Rev. 227, 264 (1958); Currie, Survival of Actions: Adjudication versus Automation in the Conflict of Laws, 10 Stan. I. Rev. 205, 251 (1958).

Another defect of such arrangements is that they would probably be influenced by estabJished conflict-of-laws doctrine, so that the rules would tend to be framed in terms of technical contacts, and forthright consideration of the competing interests would be hampered. Since we are here speaking of the possible rather than the probable, however, it may be conceded that this is a remediable defect: the states could put aside metaphysical premises, and deal cleanly with the question of which interest should be subordinated. This, however, leads only to a more serious difficulty. Where a single choice-of-law rule is under consideration, the only quid pro quo which a state receives for sacrificing its legitimate governmental interest is the rather pallid satisfaction of having contributed to the more orderly administration of interstate justice. A real exchange is possible, it seems, only if the foreign state will agree to sacrifice its interest in some other area. Such a trading off of the rights of one group of citizens for those of another is not a wholesome prospect. In short, the question whether the interest of one state should yield to that of another is not a promising subject for bargaining, bilateral or multilateral, among the states concerned.

By the same token, unilateral action by a state legislature to subordinate local interests to those of a foreign state would probably be quixotic. This is especially true in the light of conditions as they exist, since the expectation that other states will adopt the same rule and apply it consistently so as to achieve the intended uniformity is to a large extent chimerical.

- U.S. Const. Art. 4, \$2.

7 U.S. Const. Amend. $14, \$ 1$. 
consideration of the competing interests, and without adequate evaluation of the recompense which the state receives for the sacrifice of its interest. The rational pursuit of self-interest is preferable to such irrational altruism. ${ }^{8}$

It is not the purpose of this paper to offer a general defense of the concept of governmental interest as a tool of analysis. The more limited purpose is to draw attention to the important role which this concept has played in the Supreme Court's review of state decisions in the field of choice of law, and to the significance of this phenomenon for conflict-of-laws method in general. A closely related question, concerning the effect of the Constitution upon the right of access to courts in "transitory" causes of action having foreign aspects, must be reserved for separate consideration. ${ }^{9}$ We shall be concerned principally with the Full Faith and Credit Clause and the Due Process Clause of the Fourteenth Amendment, these being the provisions which most controversially provide the basis for review of state decisions as to choice of law. Other clauses providing that basis, such as the Privileges and Immunities Clause of Article IV and the Equal Protection Clause, will be considered only briefly. We shall not be concerned, except incidentally, with questions of full faith and credit to judgments. ${ }^{10}$ We shall be concerned almost exclusively with private rather than public law, leaving aside such questions as jurisdiction to tax, or to escheat, although the concept of governmental interest has played an instructive part in the determination of such questions.

Among other things, we shall find that the ideas involved in the analysis of governmental interests are not novel, but are so fundamental that they can be found, in more or less explicit form, in many of the older cases. The prime purpose will not be to establish the fact that the Supreme Court now employs such an analysis in the determination of conflict-of-laws questions at the constitutional level; that fact is widely understood and accepted. ${ }^{11}$ The major purposes

${ }^{8}$ The suggested method does not exclude the possibility of rational altruism. We may well find satisfaction in a legal tradition which shuns discrimination against nonresident aliens although such discrimination would be constitutionally permissible. See Muhall v. Fallon, 176 Mass. 266, 57 N.E. 386 (1900); but cf. 77 Pa. Stat. Ann. (Purdon, 1952 and 1957 Supp.) §563. And further analysis of specific problems may show that, when a state has determined that a local industry should bear its social costs, it may be sound policy to impose the cost upon the enterprise irrespective of who the victim is or where the harm has its impact. Cf. Schmidt v. Driscoll Hotel, Inc., 249 Minn. 376, 82 N.W.2d 365 (1957), with Eldridge v. Don Beachcomber, Inc., 342 IIl. App. 151, 95 N.E.2d 512 (1950).

${ }^{9}$ Hughes v. Fetter, 341 U.S. 609 (1951); First Nat'l Bank of Chicago v. United Air Lines, Inc., 342 U.S. 396 (1952). See note 90 infra.

${ }^{10}$ It may be noted, however, that the concept of governmental interest has played a significant role in the development of modern doctrines relating to the jurisdiction of courts. See Watson v. Employers Liability Assur. Corp., 348 U.S. 66 (1954); Kurland, The Supreme Court, the Due Process Clause, and the In Personam Jurisdiction of State Courts from Pennoyer to Denckla: A Review, 25 U. of Chi. L. Rev. 569 (1958).

"See Cheatham, Federal Control of Conflict of Laws, 6 Vand. L. Rev. 581 (1953), reprinted in Association of American Law Schools, Selected Readings on Conflict of Laws 255 (1956) (the Association collection will hereafter be cited "AALS Readings"); Dodd, The Power of the 
will be: (1) to observe carefully what an analysis in terms of state interests involves, and in particular to distinguish it from the amorphous "grouping of factors" concept and other similar tests which are sometimes utilized in conflict of laws; ${ }^{12}$ (2) to inquire into the extent to which it is competent for a court employing such an analysis to "balance" or "weigh" conflicting state interests in order to determine which is entitled to be preferred; and (3) to suggest the significance of this type of analysis for conflict of laws generally.

The results of the exploration will fall considerably short of revealing a clear and consistent course on the part of the Supreme Court. At various times the Court has: (1) said that the erronous decision of a question of choice of law by a state court raises no federal question; ${ }^{13}$ (2) seemed determined to write into the Constitution the territorialist theory of vested rights; ;4 (3) explicitly employed an analysis in terms of state interests, declining to assume the role of arbiter where legitimate interests are in conflict; ${ }^{15}$ and (4) confidently assumed the function of "weighing" the competing interests of the states concerned..$^{18}$ Yet I think the time has come to abandon the traditional strophe to the effect that all is confusion in this department. ${ }^{17}$ In spite of the fact that no wholly consistent pattern has been established, I believe we shall find:

(1) The Court has increasingly employed an analysis in terms of governmental interests, with the result that the operation of the Constitution as a restraint upon state decisions on the choice of law has been materially clarified. The employment of this type of analysis in constitutional cases surely has significance for conflict-of-laws theory in general.

(2) The emerging prixciple is that the Due Process Clause and the unimple-

Supreme Court to Review State Decisions in the Field of Conflict of Laws, 39 Harv. L. Rev. $533,547,557,559$ (1926); Hilpert and Cooley, The Federal Constitution and the Choice of Law, 25 Wash. U. L. Q. 27 (1939); Jackson, Full Faith and Credit-The Lawyer's Clause of the Constitution, 45 Col. L. Rev. 1 (1945), AALS Readings 229; Langmaid, The Full Faith and Credit Required for Public Acts, 24 Ill. L. Rev. 383 (1929); Moore and Oglebay, The Supreme Court and Full Faith and Credit, 29 Va. L. Rev. (1943); A Factual Approach to the Constitutional Law Aspects of the Conflict of Laws, 35 Col. L. Rev. 751 (1935); Full Faith and Credit to Statutes, 45 Yale L. J. 339 (1935); Overton, State Decisions in Conflict of Laws and Review by the United States Supreme Court under the Due-Process Clause, 22 Ore. I. Rev. 109 (1943); Ross, Has the Conflict of Laws Become a Branch of Constitutional Law?, 15 Minn. L. Rev. 161 (1931); Speidel, Extraterritorial Assertion of the Direct Action Statute: Due Process, Full Faith and Credit and the Search for Governmental Interest, 53 Nw. U. L. Rev. 179 (1958); Freund, Chief Justice Stone and the Conflict of Laws, 59 Harv. L. Rev. 1210 (1946).

${ }^{12}$ See Auten v. Auten, 308 N.Y. 155, 124 N.E. 2 d 99 (1954); cf. Morris, The Proper Law of a Tort, 64 Harv. L. Rev. 881 (1951), AALS Readings 575.

${ }^{13}$ Kryger v. Wilson, 242 U.S. 171 (1916).

14 New York Life Ins. Co. v. Dodge, 246 U.S. 357 (1918).

${ }^{15}$ Pacific Employers Ins. Co. v. Industrial Accident Commission, 306 U.S. 493 (1939).

${ }^{16}$ Order of United Commercial Travelers v. Wolfe, 331 U.S. 586, 624 (1947).

${ }^{17}$ See, e.g., Jackson, op. cit. supra note 11; Speidel, op. cit. supra note 11; Cheatham, op. cit, supra note 11; Moore and Oglebay, op. cit. supra note 11 . 
mented Full Faith and Credit Clause control state decision only in what I have called the "false-problem" cases: i.e., cases in which one state has a legitimate interest and the other has none.

(3) Although the Court and most commentators continue to assume that it is the prerogative of the Court to "weigh" the respective interests in cases of genuine confict, and although the Court has actually assumed to weigh and choose in isolated cases, it is becoming increasingly clear that to choose between the conflicting legitimate interests of two or more states is not a judicial function.

(4) The Constitution provides a comprehensive scheme for the resolution of interstate conflict-of-laws questions, but an essential element of that scheme is the legislative power vested in Congress, particularly under the Full Faith and Credit Clause; and confusion and frustration are inevitable so long as that power remains unexercised with respect to choice of law.

\section{Some Preliminari Constderations}

The effect of federal union upon the relations of the constituent states among themselves is a relatively neglected subject-neglected not only by legal scholars $^{18}$ and by Congress, ${ }^{19}$ but by the Founding Fathers themselves. Independent states, pursuing their respective interests through the medium of law, public and private, tend to become involved in conflicts which can be dealt with only by "the comity of nations," or by diplomacy, or by reprisal or other forms of hostile action. The formation of a federal union would seem to present the ideal opportunity for establishing restraints upon the pursuit of such interests and procedures for the resolution of such conflicts; yet there is surprisingly little in the Constitution addressed directly to these objectives. ${ }^{20}$ Most of it is found in Article IV; and of the provisions of that Article which are not obsolete, only the Privileges and Immunities Clause and the cryptic Full Faith and Credit Clause relate very obviously to interstate conflicts in the context of private law. ${ }^{21}$ Four score years after ratification of the original Constitution, in the aftermath of civil war, the Nation added the Fourteenth Amendment, whose Due Process

${ }^{18}$ See Jackson, op. cit. supra note 11, AAIS Readings at 231; Cook, The Logical and Legal Bases of the Conflict of Laws 90 (1942).

19 The powers granted to Congress under the Full Faith and Credit Clause have been exercised on just three occasions: (1) The Act of May 26, 1790, 1 Stat. 122, prescribed modes of authentication of acts, records and judicial proceedings, and in general terms prescribed the effect of records and judicial proceedings; (2) The Act of March 27, 1804, 2 Stat. 298, supplemented the Act of 1790 by including nonjudicial records and by extending the principle of full faith and credit to the acts, records and judicial proceedings of federal territories as well as of the states; (3) The 1948 Revision of the Judicial Code, 62 Stat. 947 (1948), 23 U.S.C.A. $\$ 1738$ (1950), for the first time inserted a reference to "acts" (of the legislatures) in the clause dealing with effect as distinguished from authentication.

${ }^{20}$ Of course, the vesting of certain powers in the national government, coupled with express or implied limitations on the powers of the states, operated indirectly to regulate or inhibit interstate conflicts. See especially U.S. Const. Art 1, $\$ \$ 9,10$.

${ }^{21}$ An interesting list of constitutional provisions which may bear on questions of the conflict of laws is given by Overton, op. cit. supra note 11, at $110 \mathrm{n} .6$. 
and Equal Protection clauses have assumed a significance for conflict of laws which was probably unanticipated. ${ }^{22}$ If it is indeed true that in these meager provisions we can find a comprehensive scheme for the resolution of conflict-oflaws problems, it may well be attributable, as Lord Kames said of the Scottish arrangement, to "chance perhaps more than good policy. . .."23

Of the four constitutional clauses which have been mentioned, we shall be concerned here primarily with the Full Faith and Credit and Due Process Clauses, since these are the provisions which have figured most prominently in federal review of state action in the field of conflict of laws. The areas in which these two clauses operate are not coterminous: for example, while it is clear that a state is under no obligation to give full faith and credit to the laws of a foreign country, the Due Process Clause may prohibit the disregard of an appropriate foreign law, or the application instead of an inappropriate domestic law. ${ }^{24}$ Yet in the discussion to follow the two clauses will not be separated for purposes of analysis, partly because the degree of overlap is large--larger than has at times been believed-but primarily because the essential principle underlying the operation of both clauses is the same: neither interferes with choice of law except when the law applied is that of a state having no legitimate interest in the application of its policy to the case at hand.

There are three minor questions relating to the sphere of operation of the clauses with respect to which I should like to take, for present purposes, a position that is perhaps dogmatic. Two have been somewhat mooted in the past, but I believe that subsequent consideration has laid the early doubts to rest. The third relates to a comparatively rare phenomenon, with respect to which little authority is available, but the answer seems clear. In any event, the positions taken are not indispensable to the thesis of this paper, and full development of the arguments in their support does not seem warranted. Therefore, the discussion will proceed upon the following assumptions:

1. The Full Faith and Credit Clause extends not only to the statutes ("public acts") of sister states, but also to their decisional, or common, law. That this is not made clear to the modern reader by the text of the clause is indicated by the fact that the contrary was assumed as recently as 1919-and even 1942-by Walter Wheeler Cook..$^{25}$ Professor Crosskey, however, has argued persuasively

22 A fortuitous virtue of traditional choice-of-law rules is that, having been framed principally with reference to metaphysical concepts rather than state interests, they have not often produced such discrimination as would call into play the Privileges and Immunities and Equal Protection clauses. Those clauses will assume fresh importance, however, if, in an effort to find a more rational approach to conflict-of-laws problems, we inquire frankly into the extent of legitimate governmental interest.

${ }^{23}$ Kames, Principles of Equity 267 (1760).

24 Home Ins. Co. v. Dick, 281 U.S. 397 (1930).

${ }^{25}$ See Cook, Logical and Legal Bases of the Conflict of Laws 105 (1942), originally published under the title of The Powers of Congress under the Full Faith and Credit Clause, 28 Yale L. J. 421 (1919). See also Dodd, op. cit. supra note 11, at 545, 562. 
that judicial precedents were included in the term "records"; ${ }^{26}$ the late Mr. Justice Jackson argued that they are included in the term "judicial proceedings" ${ }^{27}$ the Court has expressly, though by dictum, referred to the "faitb and credit... to which local common and statutory law is entitled under [the] Constitution and laws of the United States;"'28 and various arguments which are on the whole convincing have been advanced in support of the proposition that common law is somehow included. ${ }^{29}$

2. A state may deprive a party of due process of law by applying the law of a state having no interest in the matter, even though the law so applied is common law as distinguished from statutory law. Earlier doubts on this score seem to have rested on misconception, and have been allayed..$^{30}$

3. A state may deprive a party of due process of law by applying the law of a state having no interest in the matter, whether the law applied is that of the forum or of another state. Usually the question is raised by the court's application of the law of the forum. There is every reason, however, why the principle should apply equally to the unwarranted application of foreign law, and the Court has intimated that it does. ${ }^{31}$ Irrational altruism can be quite as mischievous and arbitrary as irrational provincialism..$^{32}$

Of the two constitutional provisions with which we are primarily concerned, only the Full Faith and Credit Clause is directly addressed to problems of the conflict of laws. Even to the extent that they are based on that clause, the conclusions suggested in this paper cannot be derived from the mere language of the Constitution, nor from the relevant constitutional history. The scanty materials which are available have been examined time after time without yielding any very satisfactory insight into the essential meaning of full faith and credit to the

${ }^{26} 1$ Crosskey, Politics and the Constitution in the History of the United States 545-47 (1953). To the same effect see Ross, op. cit. supra note 11, at 170 n. 48; Ross, "Full Faith and Credit" in a Federal System, 20 Minn. L. Rev. 140, 189 (1936).

${ }^{27}$ Jackson, op. cit. supra note 11, AALS Readings at 237-38.

${ }^{28}$ Magnolia Petroleum Co. v. Hunt, 320 U.S. 430, 436 (1943).

${ }^{29}$ See Cheatham, op. cit. supra note 11, AALS Readings at 255 , stressing the fact that anomalies would result from a distinction based on the form in which the law of the state is expressed, especially in view of the existence in some states of comprehensive codes. See also Abel, Administrative Determinations and Full Faith and Credit, 22 Iowa L. Rev. 461, 477 (1937); Dean, The Conflict of Conflict of Laws, 3 Stan. L. Rev. 388, 396 (1951); Ross, Has the Conflict of Laws become a Branch of Constitutional Law?, 15 Minn. L. Rev. 161, 170-71 (1931); Ross, "Full Faith and Credit" in a Federal System, 20 Minn. L. Rev. 140, 180-81, 189 (1936).

${ }^{30}$ See Dodd, op. cit. supra note 11 , at 538-39, 549; Ross, op. cit. supra note 11 , at 167 et seq.; Overton, op. cit. supra note 11, 159 et seq.; Dean, op. cit. supra note 29, at 397 .

${ }^{31}$ Young v. Masci, 289 U.S. 253 (1933). See also Rest., Conflict of Laws Second 20 (tent. draft 3, 1956); but cf. Ehrenzweig, Conflict of Laws 12 (1959).

32 See also Overton, op. cit. supra note 11, at 146 et seq. For an example of a case in which the application of foreign law would be, in my judgment, a denial of due process, see Currie, Survival of Actions: Adjudication versus Automation in the Conflict of Laws, 10 Stan. L. Rev. 205. 238-39 (1958). 
laws of the states..$^{33}$ The problem is to determine what meaning can reasonably be attributed to the clause in the context of the federal system as it has developed and exists today. For this purpose it is necessary, after extracting such meaning as we can from the language and history of the clause, to analyze the problems which have been presented in litigation, taking into account the character of the problems to which the clause is addressed and the limitations of the institutions which are available for dealing with them. Discussion will therefore be limited to the salient features of the constitutional history which are relevant to the problem of full faith and credit to the laws of the states, and to some fairly obvious inferences to be drawn from them.

The clause differs from its prototype in the Articles of Confederation in two principal respects: (1) in its reference to "public acts" (the clause in the Articles being limited to the "records, acts and judicial proceedings of the courts and magistrates"), and (2) in the grant to Congress of implementing powers. ${ }^{34}$ Both innovations were deliberately made, and were accounted as having considerable importance. The reference to state legislation appeared in the draft of the Committee of Detail and was contained in one form or another in every alternative proposal with the exception of Williamson's proposed substitution of the language of the Articles. ${ }^{35}$ The grant of legislative power, first contained in a proposal by Gouverneur Morris, evoked more discussion than any other feature of the clause. The committee to whom the proposal was referred limited the power to "prescribe ... the effect" to judgments, whereupon Morris promptly moved an amendment which would restore its comprehensive character. George Mason, who evidently did not follow the proceedings closely, was in favor of limiting the power to judgments and judicial proceedings. James Wilson remarked that "if the legislature were not allowed to declare the effect [of public acts as well as of judgments and judicial proceedings?], the provision would amount to nothing more than what now takes place among all independent nations." Johnson ob-

\footnotetext{
${ }^{23}$ See Abel, op. cit. supra note 29; Cook, op. cit. supra note 18 at c. IV; Corwin, The "Full Faith and Credit" Clause, 81 U. of Pa. L. Rev. 371 (1933); Costigan, The History of the Adoption of Section 1 of Article IV of the United States Constitution and a Consideration of the Effect on Judgments of that Section and of Federal Legislation, 4 Col. L. Rev. 470 (1904); 1 Crosskey, op. cit. supra note 26, at 542-57; Jackson, op. cit. supra note 11; Radin, The Authenticated Full Faith and Credit Clause: Its History, 39 Ill. L. Rev. 1 (1944); Ross, op. cit. supra note 26; Full Faith and Credit to Public Acts, 30 N.Y.U.L. Rev. 984 (1955).

34 In the Articles of Confederation the clause is the third paragraph of Article IV. The proceedings in the constitutional convention are found in 2 Farrand, Records of the Federal Convention $188,445,447-48,483-84,485,486,488-89,577-78,601,661$ (rev. ed., 1937); Madison, Journal of the Federal Convention 72, 460, 624-25, 649-50, 711, 760 (1898). These materials are conveniently assembled in Prescott, Drafting the Federal Constitution 723-26 (1941).

${ }^{35}$ The suggestion that this reference was intended to have the very narrow effect of embracing only legislative decrees of insolvency and divorce, Conflict of Laws-Full Faith and Credit as Applied to Statutes, 51 Mich. L. Rev. 267, 269 (1952), not only trivializes the constitutional provision but is in the teeth of clear evidence indicating that the final reference to "prblic Acts" was intended to exclude just such legislation from coverage. See 1 Crosskey, op. cit. supra note 26 , at $542-43$.
} 
served that Morris's amendment would "authorize the general legislature to declare the effect of legislative acts of one state in another state." Randolph considered this circumstance as "strengthening the general objection against the plan that its definition of the powers of the government was so loose as to give it opportunities of usurping all the state powers." He wished to go no farther than to authorize Congress to provide for the effect of judgments; and Virginia, along with Maryland and Georgia, voted against the Morris amendment.

As to the meaning of "full faith and credit" the record is silent. A possible clue is to be found in the language of a proposal, made by Randolph, which died in committee:

Whenever the act of any state, whether legislative, executive, or judiciary, shall be attested and exemplified under the seal thereof, such attestation and exemplification shall be deemed in other states as full proof of the existence of that act; and its operation shall be binding in every other state, in all cases to which it may relate, and which are within the cognizance and jurisdiction of the state wherein the said act was done. ${ }^{36}$

This proposal, it will be observed, omitted any grant of legislative power at all, even to prescribe the effect of judgments. Apparently Randolph felt it sufficient to refer to principles of "cognizance and jurisdiction" which he assumed had an independent existence.

So far as appears from the rather extensive literature on this subject, "full faith and credit" was not a term of art with a settled meaning. It is difficult to read into the clause, in its original context, anything more than an injunction to render unto Caesar the things which be Caesar's-without guidance as to how ownership is to be determined in the absence of legislation by Congress. As Professor Crosskey puts it, the clause required each state to give "appropriate" effect to the laws of other states. ${ }^{37}$ This much, and no more, seems clear: (1) that the clause was designed to deal comprehensively with interstate questions of conflict of laws; (2) that each state was enjoined to give due deference to the laws of other states; and (3) that existing principles were not sufficient to define

${ }^{36}$ Italics added.

371 Crosskey, op. cit. supra note 26 , at 548-49. He goes further, and defines the effect to be given as that which would answer "in every respect to what was required under the law applicable to such cases." Id., at 549. Still more specifically, he suggests that the clause, completely modernized, would read as follows: "Such effect shall be given, in each state, to the legislation, judicial precedents, and court judgments and decrees, of every other state, as will answer, in every respect, to what is required by the rules and principles of the conflict of laws." Id., at 550. The system of conflict of laws to which he refers is emphatically not that which was built by Story, and later Beale, on the foundation of Huber, but that which was regarded in the eighteenth century as a branch of the law of nations. Id., at 34-37, 552. This conception, however, does not serve to advance materially the present inquiry. The conflict of laws was in a rudimentary stage of development in the eighteenth century. In any event, an appeal to the conflict of laws as an aid to interpretation of the Full Faith and Credit Clause begs the question, since we do not know now, any more than did our forebears in the eighteenth century, how to formulate rational guides for the judicial resolution of conflicts of interest among coordinate states. But cf. Dodd, op. cit. supra note 11. 
due deference comprehensively, but must be supplemented, at least, by Congressional action.

Congress did not exercise the power, wrested by Morris and others from the Committee, to prescribe the effect in one state of the public acts of another; the Act of $1790,{ }^{38}$ after prescribing modes of authentication for acts, records, and judicial proceedings, dealt with the effect of records and judicial proceedings only. The reason for the omission can only be surmised, but the most natural explanation would seem to be that the Congress simply had no idea what to say on the general question of the effect which should be given in one state to the public acts of another. In 1948 the revisers of the Judicial Code presumed to supply the omission by a notably footless piece of draftsmanship. ${ }^{39}$ They simply added the word "acts" to the sentence prescribing the effect of records and judicial proceedings, explaining that "[ $t]$ his follows the language of Article IV, section 1 of the Constitution." They seem to have been quite oblivious of the fact that there may have been a good reason for the failure of the First Congress to prescribe the effect of public acts. They seem to have had no conception of the difficulties involved in prescribing the effect which ought to be given to the laws of one state in the courts of another. The effect of the revision was to apply to statutes the same formula which the First Congress had prescribed for records and judicial proceedings: "Such acts ... shall have the same full faith and credit ... as they have by law or usage in the courts of the state from which they are taken." 40 This formula has proved reasonably workable as to judgments, although even in that connection it has not been free from difficulty. ${ }^{41}$ As applied to public acts it is simply unintelligible. Despite the enactment of the revision, the power of Congress to prescribe the effect of public acts remains, for all practical purposes, unexercised.

\section{WORKMEN'S COMPENSATION}

In 1935, in Alaska Packers Association v. Indusirial Accident Commission, ${ }^{42}$ Mr. Justice Stone, writing for a unanimous Court, explicitly employed an analysis in terms of state interests to decide a question of the applicability of state workmen's compensation statutes under the Due Process and Full Faith and Credit Clauses. With this event, the methods of sociological jurisprudence were at last made accessible to the discipline of conflict of laws. ${ }^{43}$

38 1 Stat. 122.

${ }^{39} 62$ Stat. 947 (1948), 28 U.S.C.A. $\$ 1738$ (1950).

"Naturally, since the purpose was to define "full faith and credit," the Act of 1790 did not contain the word "full."

43 See, Williams v. North Carolina, 317 U.S. 287 (1942); Harper, The Supreme Court and the Conflict of Laws, 47 Col. L. Rev. 883, 884 et seq. (1947); Stranger Attack on Sister-State Decrees of Divorce, 24 U. of Chi. L. Rev. 376, 387-88 (1957); Bigelow v. Old Dominion Copper Mining and Smelting Co., 225 U.S. 111 (1912).

42 294 U.S. 532 (1935).

${ }^{43}$ See Beale, Social Justice and Business Costs-A Study in the Legal History of Today, 49 Harv. L. Rev. 593, 608 (1936); cf. Yatema, The Hornbook Method and the Conflict of Laws, 37 Yale I. J. 468, 474 (1928). 
The Supreme Court in Alaska Packers did not hold merely that the state in which the contract of employment is entered into may apply its own law notwithstanding the purportedly exclusive provisions of the law of the state of injury. ${ }^{44}$ Instead, the Court (1) ascertained the governmental policy expressed in the California legislation; (2) determined that, in the circumstances of the case before it, California had a legitimate interest in the application of that policy; and (3) concluded that, since California had a legitimate interest in the application of its policy, the Due Process Clause did not forbid the application of California law, and the Full Faith and Credit Clause did not require the application of Alaska law. The California policy had been explicitly formulated by the state supreme court:

[T] he policy of the act... is to charge to the industry those losses which it should rightfully bear, and to provide for the employee injured in the advancement of the interests of that industry, a certain and prompt recovery commensurate with his loss and, in so doing, lessen the burden of society to care for those whom industry has deprived, either temporarily or permanently, of the ability to care for themselves. ${ }^{45}$

California had a legitimate interest in applying this policy to the case at bar essentially because the injured employee was otherwise likely to become a public charge. The basis for the interest was substantially the same as that of the state in which the injury occured; indeed, Mr. Justice Stone said that California had "as great an interest in affording adequate protection to this class of its population as to employees injured within the state." Although the employee was a nonresident alien, ${ }^{46}$ he was hired in San Francisco for short-term seasonal work

${ }^{44}$ It is well to note at the outset that this, like most workmen's compensation cases, does not present a question of choice of law in quite the usual sense, and that for this reason such cases afford an exceptionally favorable subject for application of the analysis in terms of governmental interests. In the field of workmen's compensation, tribunals do not freely apply foreign law. See, Enforcement in One Jurisdiction of Right to Compensation under Workmen's Compensation Act of Another Jurisdiction, 6 Vand. L. Rev. 744 (1953). The California Supreme Court had held that its Commission could not apply and administer the Alaska Act, Alaska Packers Association v. Industrial Accident Commission, 1 Cal. 2d 250, 255, 34 P.2d 716, 718-19 (1934), although its reasons are open to some doubt. Atchison, T. \& S.F. Ry. Co. v. Sowers, 213 U.S. 55 (1909); Tennessee C., I. \& Ry. Co. v. George, 233 U.S. 354 (1914); Hughes v. Fetter, 341 U.S. 609 (1951); cf. Alaska Packers Association v. Industrial Accident Commission, 294 U.S. 532, 545 (1935). In consequence, the issue before the California court was not whether it would apply California law or Alaska law, but whether it would apply California law or give the plaintiff no relief. The rather obvious interest of California in supplying some remedy may have influenced the Court. See Alaska Packers Association v. Industrial Accident Commission, 294 U.S. 532, 542, 544, 545-56 (1935); Pađific Employers Ins. Co. v. Industrial Accident Commission, 306 U.S. 493, 502 (1939); cf. Lauritzen v. Larsen, 345 U.S. 571 (1953). Whether the same analysis holds good when there is opportunity for an ordinary choice of law must be determined from cases other than those involving workmen's compensation.

${ }^{45}$ Alaska Packers Association v. Industrial Accident Commission; 1 Cal.2d 250, 258, 34 P.2d 716, 720 (1944).

${ }^{46}$ In this connection the history of California's assertion of jurisdiction is interesting. By its terms the workmen's compensation act covered out-of-state injuries only if the employee was a resident of the state at the time of the injury and the contract of hiring was made in the state. See Alaska Packers Association v. Industrial Accident Commission, 294 U.S. 532, 538 (1935). In a decision which is open to considerable doubt, the California Supreme Court held that the 
in Alaska, at the conclusion of which he was to be returned to California, where his wages were to be paid. Under these "special circumstances,"47 presenting the danger that he might become a public charge, California had an "interest in protecting the employee by securing for him an adequate and readily available remedy."48

In discussing the Due Process Clause, Mr. Justice Stone thought it necessary only to establish that California had a legitimate interest in the application of its own policy; he assumed that Alaska, too, had a similar interest, which would support the application of its law and policy against an attack premised on that clause. ${ }^{49}$ When the discussion turned to the Full Faith and Credit Clause, however, the Alaska interest became material, and Mr. Justice Stone explicitly called for a comparative analysis: the conflict of interests is to be resolved "by appraising the governmental interests of each jurisdiction, and turning the scale of decision according to their weight." ${ }^{150}$ Obviously, the clause could not mean that in such a situation each state having an interest should yield to the other:

Prima facie every state is entitled to enforce in its own courts its own statutes, lawfully enacted. One who challenges that right, because of the force given to a conflicting statute of another state by the full faith and credit clause, assumes the burden of showing, upon some rational basis, that of the conflicting interests involved those of the foreign state are superior to those of the forum..$^{51}$

The result of the comparative evaluation favored California: "Its interest is sufficient to justify its legislation and is greater than that of Alaska, of which the employee was never a resident and to which he may never return." ${ }^{12}$

This conclusion raised two important questions: (1) If the employee had sought compensation in Alaska, would the courts of the territory have been compelled by the Full Faith and Credit Clause to yield to the "greater" interest of California? (2) In the process of "weighing" the competing interests of the states, will the Court take into account such details of the particular case as that the injured employee left the state of injury, never to return, or will the generalized interest of that state, predicated on probability, be sufficient?

act was in conflict with the Privileges and Immunities Clause, as granting to citizens of California a privilege withheld from citizens of other states, and that the effect of the Constitution was to invalidate the discrimination by extending the same privilege to citizens of other states. Quong Ham Wah Co.v. Industrial Accident Commission, 184 Cal. 26, 192 Pac.1021 (1920), writ of error dismissed 255 U.S. 445 (1921). No determination, legislative or judicial, that the benefits of the act should extend to nonresident aliens appears to have been made until, in the Alaska Packers case, the court remarked that the condition of residence had been "nullified by the decision in Quong Ham Wal Co. v. Indusirial Acc. Com., . . . which held that the federal Constitution extended the benefits of the act to nonresidents also." 1 Cal.2d 250, 255, 34 P.2d 716, 719 (1934).

${ }^{17}$ Alaska Packers Association v. Industrial Accident Commission, 294 U.S. 532, 543 (1935).

${ }^{48}$ Ibid.

${ }^{49} \mathrm{Id}$., at 540 .

51 Id., at $547-48$.

${ }^{50} \mathrm{Id}$. , at 547.

52 Id., at 549-50. (Italics added.) 
These questions are interrelated to such an extent that the first cannot be answered until the answer to the second is known; for the very reason the Court judged the interest of California to be greater than that of the state of injury was that the employee's temporary connection with that state had, in the particular case, been severed. The question of the interest of the state of injury was presented to the Court four years later in Pacific Employers Ins. Co. v. Industrial Accident Commission..$^{53}$ In this case the connection of the employee with the state of injury was not so casual as in Alaska Packers; he had incurred in California obligations for medical and hospital care which had not been discharged at the time of the hearing. ${ }^{54}$ Nevertheless, Mr. Justice Stone, again speaking for the Court, came close to answering the first question. The interest of the state of injury was sufficient to sustain the application of its law against an attack based on the Due Process Clause; ${ }^{55}$ the interest of the state of employment was conceded..$^{56}$ Thus squarely confronted with a conflict of legitimate interests, the Court receded perceptibly from the idea that the conflict is to be resolved by determining their relative weights, and deciding in favor of the weightier interest:

This Court must determine for itself how far the full faith and credit clause compels the qualification or denial of rights asserted under the laws of one state, that of the forum, by the statute of another state. ... But there would seem to be little room for the exercise of that function when the statute of the forum is the expression of domestic policy, in terms declared to be exclusive in its application to persons and events within the state. ${ }^{57}$

Conceivably, this might be understood as meaning that, circumstances in the particular case having made the employee's connection with the state of injury more than casual, the interests of the two states became so nearly equal that it was mot possible to choose between them. Even with this limited meaning, the retreat has ominous portents for those who would cast the Court in the role of arbiter of conflicting state interests. In its context, however, the language seems to have a broader significance. It seems to suggest that, when it is acknowledged that each state has a legitimate, or substantial, interest-an interest sufficient to justify the application of its law so far as the Due Process Clause is concerned -then a conflict is presented which cannot be resolved by the Court: each state is free to apply its own law, consistently with the Full Faith and Credit Clause. Furthermore, the Court seems to attach no particular importance to the circumstances which might be regarded as giving the state of injury a stronger interest in this case than in Alaska Packers; apparently Alaska, too, might have applied

${ }^{53} 306$ U.S. 493 (1939).

${ }^{54}$ Under the California act, the suppliers of such services were entitled to participate in the compensation proceeding to claim liens on the proceeds of the award. See Independence Indemnity Co. v. Industrial Accident Commission, 2 Cal.2d 397, 41 P.2d 320 (1935).

${ }^{55}$ Pacific Employers Ins. Co. v. Industrial Accident Commission, 306 U.S. 493, 500 (1939). ${ }^{86}$ Ibid. ${ }^{57}$ Id., at 502-3. (Italics added.) 
its law without denying full faith and credit to the laws of California. Hence the opinion foreshadows the answer to the second question: the basis for the state's interest is to be somewhat conventionalized, and is not to be determined according to the actual course of events following the injury in the particular case.

This, indeed, is the answer which the Court ultimately gave to the second question. In Carroll v. Lanza, ${ }^{58}$ the interest of the state of injury was upheld although the employee was immediately removed to a hospital in the state of his residence and employment, and remained there. Speaking for the majority, Mr. Justice Douglas said:

[The interests of the state of injury] are large and considerable and are to be weighed not only in the light of the facts of this case but by the kind of situation presented. For we write not only for this case and this day alone, but for this type of case. The State where the tort occurs certainly has a concern in the problems following in the wake of the injury. The problems of medical care and of possible dependents are among these. ... A State that legislates concerning them is exercising traditional powers of sovereignty. ... Arkansas therefore has a legitimate interest in opening her courts to suits of this nature, even though in this case Carroll's injury may have cast no burden on her or her institutions. 59

The deliberateness of this position is underscored by the fact that three justices, in dissent, took sharp issue with it, contending for a "balancing" of the respective state interests in the light of the circumstances of the individual case. ${ }^{60}$

All three of these decisions had to cope with the authority of the earlier case of Bradford Electric Light Co. v. Clapper, ${ }^{61}$ which held that the Full Faith and Credit Clause required the state of injury to defer to the purportedly exclusive workmen's compensation act of the state of employment. There the employer was a Vermont corporation, with its principal place of business in that state; the employee was a resident of Vermont; and the contract of employment was entered into in Vermont. One evening the employee was sent just across the river which divides Vermont from New Hampshire, to replace burned-out fuses in a substation located there, ${ }^{62}$ and was electrocuted. He left no dependents, and under the workmen's compensation law of Vermont his administrator was entitled only to a small sum to provide for burial expenses. ${ }^{63}$ The workmen's compensation act of New Hampshire permitted the employee or his representative to elect, after the injury, to sue for damages at common law rather than for compensation; and so an administrator, a resident of New Hampshire, brought in the New Hampshire courts an action for wrongful death which was removed to the United States district court because of diversity of citizenship.

In holding that full faith and credit to the law of Vermont precluded recovery under the New Hampshire law, Mr. Justice Brandeis first remarked that:
58349 U.S. 408 (1955).
${ }^{60}$ Id., at $420-21$, n. 3.
${ }^{59}$ Id., at 413.
61 286 U.S. 145 (1932).
62 See the same case in the Court of Appeals, 51 F.2d 992, 993 (C.A.1st, 1931).
${ }^{63}$ Id., at 994. 
If the conflict presented were between the laws of a foreign country and those of New Hampshire, its courts would be free, so far as the restrictions of federal law are concerned, to attach legal consequences to acts done within the State, without reference to the undertaking of the parties, entered into at their common residence abroad, that such consequences should not be enforced between them. ${ }^{64}$

If this is true, it must follow that New Hampshire had a legitimate interest in the application of its law, sufficient to withstand attack under the Due Process Clause; for the Court had held in Home Ins. Co. v. Dick that when a state having no interest in the matter applies its law to defeat rights asserted under the law of a foreign country there is a denial of due process. Hence the decision is directly in conflict, to this extent, with the subsequent holding in the Pacific Employers case, that a state having a legitimate interest, in the due process sense, is not required by the Full Faith and Credit Clause to defer to the law of a sister state. ${ }^{66}$ To show that full faith and credit was required despite the conceded contrary interest of the forum state, Mr. Justice Brandeis, rejecting the plaintiff's contention that deference to the law of Vermont would give that law "extraterritorial effect," universally treated as creating "a statutory relation" between the parties. "The relation between Leon Clapper and the Company was created by the law of Vermont; and as long as that relation persisted its incidents were properly subject to regulation there." 68 The Vermont statute would have prevented a common-law action in Vermont; and

[t]he rights created by the Vermont Act are entitled to like protection when set up in New Hampshire by way of defense to the action brought there. If this were not so, and the employee or his representative were free to disregard the law of Vermont and his contract, the effectiveness of the Vermont Act would be gravely impaired. For the purpose of that Act, as of the workmen's compensation laws of most other States, is to provide, in respect to persons residing and businesses located in the State, not only for employees a remedy which is both expeditious and independent of proof of fault, but also for employers a liability which is limited and determinate. ${ }^{69}$

Thus, on grounds partly conceptual and partly pragmatic, Mr. Justice Brandeis held that the interest of Vermont was superior to that of New Hampshire, and that under the Full Faith and Credit Clause the latter must give way. ${ }^{70} \mathrm{Mr}$.

64 Bradford Electric Light Co. v. Clapper, 286 U.S. 145, 154 (1932).

${ }^{65} 281$ U.S. 397 (1930) (cited by Mr. Justice Brandeis, in another connection, on the same page of the opinion from which the quotation above is taken). Mr. Justice Brandeis himself was the author of the opinion in the Dick case.

66306 U.S. 493, 500 (1939).

${ }^{67}$ Bradford Electric Light Co. v. Clapper, 286 U.S. 145, 156-57 (1932).

${ }^{68} \mathrm{Id}$., at 158.

${ }^{69}$ Id., at 159.

${ }^{70}$ The fourth part of the opinion, in which Mr. Justice Brandeis dealt with the contention that deference to New Hampshire law would be contrary to the public policy of New Hampshire, will be considered infra. 
Justice Stone concurred specially, on the ground that decision of the constitutional question was unnecessary, since it might be assumed that New Hampshire courts would voluntarily apply Vermont law. ${ }^{71}$

The Clapper case was not a formidable obstacle to the decision in Alaska Packers since, loosely speaking, each upheld the applicability of the law of the state of employment as against the competing law of the state of injury. But Clapper had required the forum and state of injury to put aside its law in favor of the law of the state of employment, thus giving to the Full Faith and Credit Clause an interpretation which Mr. Justice Stone found unacceptable. Despite his reference in Alaska Packers to "weighing" the conflicting interests, he was on record as believing that the fact that the forum had a legitimate interest in the application of its own policy was sufficient to preclude displacement of the forum's law by the Full Faith and Credit Clause, ${ }^{72}$ and Clapper represented a contrary view. Hence he dealt at some length with that case, distinguishing it, essentially, on the ground that there it did not appear that giving effect to the Vermont statute would be contrary to any declared policy of New Hampshire. ${ }^{73}$

In the Pacific Employers case the Clapper decision apparently presented a real obstacle, since the question was whether the state of injury must defer to the purportedly exclusive compensation law of the state of employment. As in Alaska Packers, Stone distinguished Clapper on the ground that it did not appear that recognition of Vermont law would be obnoxious to New Hampshire policy-thus discarding all of the Clapper opinion except that portion of the fourth part in which Mr. Justice Brandeis had dealt with the "local public policy" argument:

The Clapper case cannot be said to have decided more than that a state statute applicable to employer and employee within the state, which by its terms provides compensation for the employee if he is injured in the course of his employment while temporarily in another state, will be given full faith and credit in the latter when not obnoxious to its policy. ${ }^{74}$

Carroll v. Lanza posed the supreme test for the authority of Clapper. In a sympathetic attempt to reconcile the apparent conflict between Clapper and Pacific Employers, one might reason that the common law of a state, in providing a cause of action for injuries negligently inflicted, does not express a social and economic policy of quite the same order as does a modern reform statute such as a workmen's compensation act-or, at least, that the policy expressed in

${ }^{71}$ Id., at 163.

72 "I can find nothing in the history of the full faith and credit clause, or the decisions under it, which lends support to the view that it compels any state to subordinate its domestic policy, with respect to persons and their acts within its borders, to the laws of any other." Id., at 164 (concurring opinion).

${ }^{73}$ Alaska Packers Association v. Industrial Accident Commission, 294 U.S. 532, 548-49 (1935).

${ }^{74}$ Pacific Employers Ins. Co. v. Industrial Accident Commission, 306 U.S. 493, 504 (1939). 
the common law is not so evident, and that a federal court may excusably fail to notice it unless it is somehow made explicit by the state courts. No such way of escape was open in Carroll, since there the forum and state of injury was explicitly opposing its common-law remedies to the workmen's compensation law of the state of employment. Indeed, the defendant in Carroll sought to escape the fatal authority of Pacific Employers by just such a contention: although the forum and state of injury can apply its workmen's compensation statute notwithstanding the statute of the state of employment, here, as in Clapper, it is only the common law of the state of injury that is applied. But the Court said: "That is not in our judgment a material difference. Whatever deprives the remedy of the home State of its exclusive character qualifies or contravenes the policy of that State and denies it full faith and credit, if full faith and credit is due." ${ }^{\prime 75}$ It proceeded to emphasize the legitimacy of the interest of the state of injury in applying its governmental policy, despite the fact that that policy found expression only in the common law ${ }^{76}$ Having arrived at this point, the Court could no longer distinguish Clapper on the ground that no policy of the state of injury had been apparent. It simply said that in Pacific Employers the Court "departed ... from" the Clapper decision, and "proceeded on the premise, repeated over and over again in the cases, that the Full Faith and Credit Clause does not require a State to substitute for its own statute, applicable to persons and events within it, the statute of another State reflecting a conflicting and opposed policy." "77

That a precedent so thoroughly stripped of vitality need not be counted as detracting from the thesis under discussion hardly needs further demonstration. I should like to go farther, however, and suggest that, carefully considered on its facts, the Clapper case is actually consistent with that thesis and with the three subsequent cases. The action in Clapper was for wrongful death; the three sub-

75349 U.S. 408, 412 (1955).

${ }^{76} \mathrm{Id}$., at 413 . The Court made no attempt to distinguish Clapper on the ground that there the action was against the employer, while in the case before it the action was against a third person.

77 Id., at 412 . Two intermediate cases in the series on workmen's compensation require only brief mention. In Ohio v. Chattanooga Boiler \& Tank Co., 289 U.S. 439 (1933), Tennessee was the state of employment and the domicile of the parties, and the employee was killed while on temporary assignment in Ohio. The employer appeared specially in the compensation proceeding in Ohio to contest jurisdiction, but made no defense. The award having been paid out of the state fund, Ohio invoked the original jurisdiction of the Court to secure reimbursement. After hinting that failure to invoke the Full Faith and Credit Clause in the compensation proceeding might be regarded as precluding reliance on it in the pending action, the Court held that the rule of the Clapper case was inapplicable because the Tennessee Act did not purport to foreclose recovery by the employee in the state of injury. No defense was made on due process grounds.

In Cardillo v. Liberty Mutual Ins. Co., 330 U.S. 469 (1947), the Court held that the District of Columbia (the place of employment and the residence of the parties) did not violate either the Due Process Clause or the Full Faith and Credit Clause by applying its statute to an injury sustained in Virginia. The opinion of Mr. Justice Murphy contains a brief but significant analysis of the District's policy and its interest in the application of that policy to the case at bar. Id., at 476. 
sequent cases involved personal injuries not resulting in death. The governmental policy embodied in a wrongful death statute is not the same as that involved in the law of personal injuries, and the interest of a state in applying its policy is not necessarily determined in the same way in both cases. ${ }^{78}$ In a loose and abstract way, to be sure, one may say that the state of injury has an "interest" in securing compensation whether the injured person dies or not: there is the same need to see to it that the expenses of medical and hospital care, or even of burial, do not fall upon the state or its residents. But before a state can be said to have a legitimate interest in the application of its policy, it must first have a policy; and New Hampshire had no such policy as would support a finding that it had an interest in the application of its law in the Clapper case. The New Hampshire wrongful death statute, modeled on Lord Campbell's Act, provided that the damages recovered should "belong and be distributed to" certain surviving dependents, or to the heirs; ${ }^{79}$ they were not assets of the estate, available for the satisfaction of claims of creditors of the deceased. ${ }^{80}$ New Hampshire therefore had no policy for the protection of local Samaritans where injury in the state resulted in death; ${ }^{81}$ the policy of its wrongful death act was apparently only one of securing compensation to dependents, or heirs, for the deprivation of support or expectations. The fact of injury or death in the state was therefore irrelevant to New Hampshire's policy. The decedent left no dependents, ${ }^{82}$ and it does not appear that any of his heirs were (if the fact should be relevant) residents of New Hampshire. It follows that New Hampshire had no interest in the application of its wrongful death statute, ${ }^{83}$ and that the Court properly held that the Full Faith and Credit Clause required deference to the law of the state having an interest. This suggestion is offered frankly as a latter-day rationalization of the result, without pretense that it was a ground for the decision; nevertheless, there are passages in the opinion which may be taken as indicating that Mr. Justice Brandeis was not unaware of this aspect of the case. ${ }^{84}$

${ }^{78}$ See Currie, Survival of Actions: Adjudication versus Automation in the Conflict of Laws, 10 Stan. L. Rev. 205, 221 n. 64 (1958), where the distinction is elliptically treated.

795 N.H. Rev. Stat. Ann. (1958) c. 556, $\$ 9$ et seq.

${ }^{80}$ Davis v. Herbert, 78 N.H. 179, 97 Atl. 879 (1916), is painfully apropos.

${ }^{81}$ Cf. the provisions of the California workmen's compensation act, note 54 supra.

${ }^{82}$ Bradford Electric Light Co. v. Clapper, 51 F.2d 992, 994 (C.A.1st, 1931).

${ }^{83}$ Unless it could be maintained, as is conceivable, that a purpose of the New Hampshire statute was to discourage negligent conduct within the state. Cf. Gordon v. Parker, 83 F.Supp. 40 (D. Mass., 1949). But no such purpose was made explicit by New Hampshire, and such statutes are usually regarded as having a compensatory purpose even when they have markedly "penal" aspects. See Loucks v. Standard Oil Co., 224 N.Y. 99, 120 N.E. 198 (1918).

84 "Leon Clapper was not a resident there. . . . So far as appears, he had no dependent there. It is difficult to see how the State's interest would be subserved, under such circumstances, by burdening its courts with this litigation." Bradford Electric Light Co. v. Clapper, 286 U.S. 145, 162 (1932). "We have no occasion to consider whether if the injured employee had been a resident of New Hampshire ... or had left dependents there, recovery might validly have been permitted under New Hampshire law." Id., at 163. 
Two similar terms-"policy" and "Iocal public policy"-figure somewhat confusingly in the discussion of the problem presented by these four cases, and, indeed, of the problem of choice of law generally. The need for clarifying these concepts and their function becomes apparent when we consider the fourth part of the majority opinion in Clapper. The structure of the opinion is significant. In the preceding portions, Mr. Justice Brandeis had held that the law of Vermont was the proper law to determine the rights and obligations arising out of the employment relation; under that law the employer had acquired rights which, under the Full Faith and Credit Clause, were (prima facie, at least) entitled to respect in other states. Fraving thus settled the question of which law was appropriately applicable, Mr. Justice Brandeis turned to consideration of what he obviously regarded as a different matter: conceding that the properly applicable law was that of Vermont, might not New Hampshire nevertheless decline to recognize rights created under that law on grounds of local public policy? And here he gave forceful and quotable expression to an idea which has had a profound and unfortunate influence on conflict-of-laws theory. He conceded that under the precedents a state may decline to enforce rights created under the laws of a sister state for reasons of local public policy.

But the Company is in a position different from that of a plaintiff who seeks to enforce a cause of action conferred by the laws of another State. The right which it claims should be given effect is set up by way of defense to an asserted liability; and to a defense different considerations apply, Compare Home Ins. Co. v. Dick, 281 U.S. 397, 407,408 . A State may, on occasion, decline to enforce a foreign cause of action. In so doing, it merely denies a remedy, leaving unimpaired the plaintiff's substantive right, so that he is free to enforce it elsewhere. But to refuse to give effect to a substantive defense under the applicable law of another State, as under the circumstances here presented, subjects the defendant to irremediable liability. This may not be done. ${ }^{85}$

This is a plausible idea, effectively stated. It has been widely accepted. ${ }^{86}$ Nevertheless, it is fallacious and misleading.

It may be observed, in the first place, that the denial of a remedy is an effective impairment of the asserted right in those situations in which, as a practical matter, there is only one forum in which the action can be brought. ${ }^{87}$ But the

85 Id., at 160 .

${ }^{86}$ Hancock, Torts in the Conflict of Laws 39, 54 et seq. (1942); Cheatham, op. cit. supra note 11, AAIS Readings at 255, 265; Ross, op. cit. supra note 11; Freund, op. cit. supra note 11, at 1227 (semble); cf., Langmaid, op. cit. supra note 11, at 418-19; Paulsen and Sovern, "Public Policy" in the Conflict of Laws, 56 Col. L. Rev. 969, 979-80, 1016 (1956).

${ }^{87}$ Cf., Ciampitiello v. Campitello, 134 Conn. 51, 54 A.2d 669 (1947); Kentucky Auto Finance Corp. v. Paramount Auto Exch. Corp., 262 U.S. 544, 549-50 (1923). Moreover, the argument is altogether too facile in its assumption that, when a state refuses relief on grounds of local public policy, the plaintiff is free to pursue his claim in another jurisdiction, assuming that he can find a suitable one. The problem of what constitutes a judgment "on the merits" is a difficult one, see Angel v. Bullington, 330 U.S. 183 (1947), and depends, at least in the first instance, on the law of the state of rendition. In the case cited by Mr. Justice Brandeis as typical, it is difficult to tell whether the judgment was "on the merits" or not. Union Trust Co. v. 
difficulty goes much deeper. At least in the context of a constitutional system which commands full faith and credit, the concept of an "applicable" law which nevertbeless need not be applied if it is distasteful to the forum is a contradiction in terms. If it means anything, the requirement of full faith and credit to the laws of a sister state must mean that, once it has been determined (by whatever means) that, of all states conceivably associated with a case, one and only one furnishes the law which is the appropriate source of the rule of decision, other states must defer to that law for that purpose. ${ }^{88}$ Moreover, the argument begs the question. It assumes that the "applicable" law can be ascertained by some process other than an analysis of the governmental policies and interests of the states involved; only on this assumption does state policy become a secondary consideration. But the very question before the Court was: How are we to determine the applicable, or appropriate law-the law to which full faith and credit is required? Mr. Justice Brandeis supposed that that law could be identified as Vermont's because Vermont, as the state in which the employment relation was established, had a rightful claim to regulate the relation, and because it was desirable, at least in the judgment of Vermont, that there be uniform recognition of the limits placed by that law on the liability of the employer. But the subsequent cases strongly suggest, if they do not establish, that the appropriate law can be determined only by reference to the policies and interests of the states concerned. If a state has no legitimate interest in the matter, its invocation of local public policy, even as a reason for denying relief, should not be tolerated; if it has a legitimate interest, then its law should be "applicable," though another state may also have a rightful claim, whether the foreign law is relied on as the basis for a claim or as a defense. ${ }^{89}$ Thus, since New Hampshire had no legitimate interest in the application of its wrongful death statute in the Clapper case, the application of that law was, as the Court held, a denial of full faith and credit to the law of Vermont-and, I would add, a denial of due process as well.

Grosman, 245 Fed. 610 (C.A. 5th, 1916). If, as is probable, Mr. Justice Brandeis meant that the state is justified in invoking its public policy to deny relief only when it leaves unfettered the right of the plaintiff to pursue his remedy elsewhere, the legal obstacles to the enjoyment of that right are nevertheless formidable. Thus if the plaintiff files suit in a second forum, and the defendant pleads a prior judgment in his favor which purports to be on the merits, established doctrine precludes the plaintiff from attacking that judgment on the ground that it constitutes a denial of full faith and credit; his only recourse is to seek direct review of the first judgment. Treinies v. Sunshine Mining Co., 308 U.S. 66 (1939). See also, Nussbaum, Public Policy and the Political Crisis in the Conflict of Laws, 49 Yale L. J. 1027 (1940), A.A.L.S. Readings, 220.

${ }^{88}$ This is not a statement of agreement with the advocates of a "hard and fast" constitutional rule requiring the states to entertain causes of action predicated on the laws of sister states. See Reese, Full Faith and Credit to Statutes: The Defense of Public Policy, 19 U. of Chi. L. Rev. 339, 346 (1952). Advocacy of such a rule (1) assumes that the applicability of the sister state's law is controlled by mechanically applied territorialist principles and (2) overlooks the possibility that the forum's legitimate policies relative to judicial administration may be entitled to recognition.

${ }^{89}$ Cf. Holzer v. Deutsche Reichsbahngesellschaft, 277 N.Y. 474, 14 N.E.2d 798 (1938). 
But if the action had been for personal injuries, New Hampshire would have had a relevant policy and a legitimate interest in the application of that policy, and the local court should be free to apply its law irrespective of the fact that the law of Vermont was invoked defensively.

Mr. Justice Stone in Alaska Packers explicitly repudiated the Brandeis fallacy. He first observed that, when the policies of two states are in conflict, the Full Faith and Credit Clause can hardly be understood as requiring each state to defer to the other, and that of necessity the Court must determine the extent to which the laws of one may qualify or deny rights asserted under the laws of the other. He continued:

The necessity is not any the less whether the statute and policy of the forum is set up as a defense to a suit brought under the foreign statute or the foreign statute is set up as a defense to a suit or proceedings under the local statute. In either case, the conflict is the same. In each, rights claimed under one statute prevail only by denying effect to the other. In both the conflict is to be resolved, not by giving automatic effect to the full faith and credit clause, compelling the courts of each state to subordinate its own statutes to those of the other, but by appraising the governmental interests of each jurisdiction. ... .90

This ought to have disposed of the matter. As we shall see, however, the fallacy returns time after time to plague discussions of the choice of law.

\section{Commercial Insurance}

As an instrument of constitutional interpretation, the territorialist theory of vested rights apparently attained its apotheosis in New York Life Ins. Co. v. Dodge..$^{91}$ Dodge, a resident of Missouri, applied to the company, a New York corporation licensed to do business in Missouri, for a policy of insurance on his life, naming his wife as beneficiary. That the policy was a Missouri contract was "undisputed and clear."92 Taking advantage of a provision in the policy, the insured applied for and obtained a loan, some of the proceeds of which were ap-

90294 U.S. 532, 547 (1935). A reminder is perhaps in order that we are here concerned with choice of law-specifically, with the constitutional limits upon the freedom of a state to apply its own law as the rule of decision instead of the law of another state for which recognition is demanded. The somewhat different considerations which are involved in determining whether a state may simply refuse, on grounds of policy relating to the administration of its judicial establishment, to entertain in a cause of action having foreign aspects, must be reserved for separate treatment.

The point to be made here is that, once it has been determined that a foreign state has an interest in the application of its law and policy and that the forum state has none, the Constitution precludes disposition of the case according to the contrary law or policy of the forum, whether the disposition is "on the merits" or not. A different, though closely related, problem arises when there is no hostility between the laws of the respective states so far as the rule of decision is concerned, but the forum declines to entertain the action for policy reasons which supposedly relate to the administration of local courts. Cf. Hughes v. Fetter, 341 U.S. 609 (1951); First National Bank of Chicago v. United Air Lines, 342 U.S. 396 (1952). See notes 9, 88 supra, and 281,284 infra.

92246 U.S. 357 (1918). $\quad 92$ Id., at 372. 
plied to the payment of premiums. The policy lapsed and the company, in accordance with New York law and the terms of the loan agreement, applied the entire reserve value to repayment of the loan. Thereafter the insured died. The widow brought action on the policy in Missouri, relying on the Missouri nonforfeiture statute and on the fact that when the policy lapsed it had a reserve value threefourths of which, after deducting loan proceeds applied to payment of premiums, was sufficient to keep the policy in force at face value for a term extending beyond the date of the insured's death. The statute provided:

No policies of insurance on life hereafter issued by any life insurance company authorized to do business in this state . . shall . . . be forfeited or become void, by reason of non-payment of premiums thereof, but it shall be subject to the following rules of commutation, to wit: The net value of the policy, when the premium becomes due, and is not paid, shall be computed ... and after deducting from three-fourths of such net value, any notes or other evidence of indebtedness to the company, given on account of past premium payments on said policies ... the balance shall be taken as a net single premium for temporary insurance for the full amount written in the policy. ... ${ }^{93}$

The trial court gave judgment for the plaintiff, the Missouri court of appeals affirmed, and the company brought a writ of error. The Supreme Court reversed by a vote of five to four, holding in an opinion by Mr. Justice McReynolds that the loan agreement was a New York contract and that the statute as applied was a violation of the Due Process Clause.

The decision may be regarded as authority for the proposition that the law of the state where a contract is made is controlling, and that the Constitution forbids another state, whatever its interest in the case, to apply its contrary law. Regarded in that light, the decision is rigidly conceptualistic, and quite incompatible with the thesis that choice-of-law problems at the constitutional level are, and ought to be, determined by an analysis of the interests of the states involved. The opinion of Mr. Justice McReynolds appears to ride roughshod over the obvious interest of Missouri in regulating life insurance contracts where both the insured and the beneficiary are at all relevant times residents of the state, and where the company is a foreign corporation licensed to do business in the state.

Still regarding the decision in this light, we may take some comfort in Mutual Life Ins. Co. v. Liebing, ${ }^{94}$ which can be evaluated only as a strategic retreat from the dangerous and untenable position taken in Dodge. In circumstances parallel to those in Dodge, the unanimous Court, speaking through Mr. Justice Holmes, found that the loan agreement was a Missouri-not a New York-contract, and upheld the application of the Missouri nonforfeiture statute. It is not possible to accept the reasoning on the basis of which the Court concluded that, while the Dodge contract was made in New York, the Liebing contract was made in Mis-

$$
{ }^{93} \text { Id. , at 366-67. }
$$

94259 U.S. 209 (1922). 
souri. According to the argument, the policy provision in Liebing was an offer, acceptance of which was complete when the loan application was delivered to the company's agent in Missouri; on the other hand in Dodge the policy provision was a mere statement of willingness to entertain offers, and the application was only an offer, resulting in no contract until it was accepted by the company in New York. The policy provision in Liebing was: "the company will . . loan amounts within the limits of the cash surrender value;"95 in Dodge it was "Cash loans can be obtained ... on demand." Obviously uncomfortable with this effort to distinguish the cases, Mr. Justice Holmes went on to say that, even if the loan application rather than the policy provision in Liebing were regarded as the offer, the acceptance was not complete until the check was delivered to the insured in Missouri. ${ }^{97} \mathrm{He}$ did not contrast the facts of the Dodge case as to this point. It is necessary to read closely the dissenting opinion of Mr. Justice Brandeis in that case to learn that in Dodge there was no delivery of any check: the proceeds of the nominal loan were insufficient to cover an existing loan on the policy plus the premium then due, and it was actually necessary for the insured to make a supplementary payment to cover the premium.98

Assuming that there is some difference between the language of the two policies which the ordinary legal mind is unable to appreciate, or that there is some significance in the fact that Mr. Dodge did not receive the check to which he would have been entitled if he had not already owed the company more than the amount of the loan, it is fantastic to suppose that the constitutional authority of Missouri to regulate insurance on the lives of its residents should stand or fall on the basis of such subtleties of phrase or fortuities of circumstance. When we add the fact (shortly to be demonstrated) that in its earlier decisions the Court had indulged no such disregard of Missouri's interests as the Dodge case implied, the conclusion seems inescapable that Liebing was a necessary, though humiliating, retreat.

Yet this conclusion leaves some troublesome questions unanswered. Under the influence of the vested rights theory courts can reach some weird results; ${ }^{99}$ yet the influence of that theory on the result in Dodge is not manifest: Mr. Justice McReynolds paid it no such homage as Mr. Justice Holmes had on prior occasions. ${ }^{100}$ Was there, perhaps, a different explanation for the decision? Moreover, why should Holmes-the Court's great champion of the vested rights the-

${ }^{95} \mathrm{Id}$., at 214.

${ }^{98} 246$ U.S. 357,368 (1918).

${ }^{97} 259$ U.S. 209, 214 (1922). This point was singled out for effective criticism in the company's Petition for Rehearing at 1 et seq.

98246 U.S. 357,380 (1918).

${ }^{99}$ See, e.g., Cuba R.R. v. Crosby, 222 U.S. 473 (1912), discussed in Currie, On the Displacement of the Law of the Forum, 58 Col. I. Rev. 964, 965 (1958).

${ }^{100}$ See Cuba R.R. v. Crosby, 222 U.S. 473 (1912); Slater v. Mexican National R. Co., 194 U.S. 120 (1904). 
ory-make himself ridiculous in the eyes of future generations of law students by conjuring up sophistic distinctions in order to destroy the precedent which gave that theory constitutional status? Above all, why should Holmes put on such a performance for the sake of reaching a result, so far as the immediate case was concerned, which was obviously distasteful to him? The concluding sentence of his opinion was:

In whichever way regarded the facts lead to the same conclusion, and although the circumstances may present some temptation to seek a different one by ingenuity, the Constitution and the first principles of legal thinking allow the law of the place where a contract is made to determine the validity and the consequences of the act. ${ }^{101}$

The persistent echo of the cryptic clause in italics spurs the search for further light on the decisions. What were the circumstances which tempted Holmes to reach by ingenuity a result different from the one he had reached by disingenuousness? There is an answer, and it establishes, I think even more powerfully than the more conventional analysis of the two cases, that Dodge is no obstacle to the thesis of this paper. In this light, Dodge does not represent even the temporary triumph of the theory of vested rights over analysis in terms of state interests. On the contrary, viewed in the light of the actual facts, the result in the Dodye case appears to be thoroughly justified on the ground that Missouri had no legitimate interest in the application of its asserted policy.

The illuminating fact, buried in a footnote to the majority opinion in Dodge ${ }^{102}$ and given no explicit attention in any of the opinions, is that the Missouri nonforfeiture statute quoted above was not the law of Missouri at the time when either of the two loan agreements was made. It was in force when the policies were issued; but on March 27, 1903, it was amended so as to authorize deduction from the net value of the policy not only of notes given on account of premium payments, but also of "any other evidence of indebtedness to the company." Thus, after March 27, 1903, there was no conflict between the law of Missouri and that of New York; both authorized deduction of all obligations to the company, not merely of obligations incurred to pay premiums. The application for the loan in Dodge was made on November 9, 1906. ${ }^{103}$ The application for the loan in Leibing was made on October 7, 1904. ${ }^{104}$ Thus, at the time of the loan agreements, Missouri had no policy of protecting its residents against agreements which would permit application of the reserve value to the payment of all policy loans; there was no conflict of laws. The Dodge case confronted the Court with this situation: the insured had entered into an agreement with the company permitting

101 Mutual Life Ins. Co. v. Liebing, 259 U.S. 209, 214 (1922)(italics added).

102 New York Life Ins. Co. v. Dodge, 246 U.S. 357, 367 n. 1 (1918).

${ }^{103}$ Id., at 369 . As has been noted above, this was not the first loan on the policy, although it is the only one discussed in the opinion of the Court. But the original loan was made in August, 1903, Transcript of Record at 28, some five months after the amendment of the Missouri statute.

${ }^{104}$ Transcript of Record at 87; cf. Mutual Life Ins. Co. v. Liebing, 259 U.S. 209, 212 (1922). 
application of the reserve value to the repayment of the loan. This agreement was not intrinsically unfair, and was sanctioned by the laws of both Missouri and New York as they stood at the time. In accordance with that agreement, the company in October, 1907, applied the reserve value to the payment of the loan and terminated the policy. In January, 1915-nearly eight years later-the beneficiary demanded the face value of the policy, claiming the benefit of the Missouri nonforfeiture law which had ceased to provide the claimed protection before the loan agreement was made. There is little ground for wonder that the Court was willing to go to some length in order to upset the judgment in her favor.

The wonder is that the Court took the plaintiff's primary position so seriously. The claim to recovery could be based only on the contention that, the policy having been issued at a time when the nonforfeiture statute was in force in its original form, that statute became a part of the contract to such an extent that the provisions relating to the treatment of loans upon commutation became permanently fixed, and were applicable to any loans made in the future; and, further, that, since the contract thus gave the insured a right to obtain loans on terms which included all the provisions of the original nonforfeiture statute, to construe the 1903 amendment as altering those terms would be to impair the obligation of the contract. Such an argument seems far-fetched in the extreme, and in the entire course of the litigation it was never stated in the full and explicit terms which would have revealed its weakness. Counsel for Mrs. Dodge did argue generally that the terms of the nonforfeiture statute were incorporated in the policy, and that "a decision now holding the non-forfeiture statute unconstitutional to affect the policy in question would be an impairment of contract ..."1:105 but the cases cited did not involve loans-much less loans obtained after the statute had been amended. Throughout, the case was presented to the Court by counsel for both sides as if the 1903 amendment had no bearing; and, of course, no question of impairment of the obligation of contracts was directly before the Court, since the Missouri court had not applied the 1903 amendment to abrogate any right claimed under the policy. By acquiescing in this presentation, and in the assumptions of counsel regarding the temporal application of the nonforfeiture statute, the Court left itself only one way of escape: by limiting the statute's territorial application.

Thus it is clear what the circumstances were which tempted Mr. Justice Holmes, in Liebing, to seek a means of denying recovery. What is not so clear is why, when he could have achieved that result by the simple device of holding Dodge controlling, he did not do so, but instead resorted to implausible arguments in order to distinguish the earlier case. Any explanation of this strange behavior must of necessity be speculative. Perhaps, after four years, Holmes was persuaded by Brandeis' dissent in Dodge that the loan agreements in both

${ }^{105}$ Brief for Defendant in Error at 11 (italics added); see also id., at 42; cf. Argument for Defendant in Error, 246 U.S. 357, 362 (1918). 
cases were so intimately related to Missouri that, despite technicalities of offer and acceptance, both should be regarded as "Missouri contracts;" and, as a true territorialist, he felt a strong compulsion to defer to the law of the place of contracting despite the unpleasantness of the result. Perhaps, also, he feared that to follow the Dodge case might place the Court in an anomalous position with respect to the Contracts Clause. ${ }^{106}$ If the Court were to hold forthrightly that Missouri had no interest in the application of its nonforfeiture statute to the loan contract in question, because the governmental policy on which that interest must be predicated had been abandoned before the loan contracts were made-and this, it seems now, is a course which the Court might well have taken-the effect would be to give controlling effect to the 1903 amendment, and this might invite a petition for rehearing on the ground that, so construed, the amendment impaired the obligation of the original contract. Such a petition, I believe, would have lacked merit; but the Court in 1922 may not have been so sure of this. At any rate, meritorious or not, such a petition would have placed the Court in an awkward position. The Missouri Court had not construed the amendment as abridging rights claimed under policies issued prior to its adoption. The Supreme Court, therefore, would be placed in the position of having to decide whether its own construction of the amendment gave that legislation an effect which the Constitution prohibited the state from giving it, and which the state court disclaimed. If $I$ am right in my belief that the amendment was a motivating factor in the Dodge case, then that case came perilously close to giving the amendment controlling effect, and to follow it might precipitate the question under the Contracts Clause despite the rhetoric of offer and acceptance. However this may be, it seems clear that Dodge does not represent so much the ascendency of the philosophy of vested rights as it does the use of that philosophy as an expedient for denying to a state having no relevant policy the right to apply its law; and of the two cases, it is Liebing rather than Dodge that is rigidly territorialist, since it upholds the applicability of the law of the state of contracting where that state has no real interest. This is not surprising, in view of Holmes' known addiction to the territorialist theory.

Examination of the Court's earlier decisions in the insurance field will demonstrate that the Court had previously, and rather consistently, applied an analysis in terms of state interests, and will incidentally furnish some further support for the interpretation of Dodge and Liebing which has just been suggested.

The Missouri nonforfeiture statute was before the Court in Equitable Life Assurance Society v. Clements. ${ }^{107}$ The case came up from a lower federal court, jurisdiction being based on diversity of citizenship, and no constitutional question was decided. No policy loan was involved; the question was simply whether the lapsed policy continued in force for a term at face value, as provided by the Missouri statute, or whether at most the plaintiff was entitled to paid-up in-

${ }^{106}$ U.S. Const. Art. I, $\$ 10$.

307140 U.S. 226 (1891). 
surance in a lower amount, as provided by a nonforfeiture clause of the policy which was presumably valid under the law of New York. In those pre-Erie days, the Court had only to decide for itself what law governed. It held that the policy was a Missouri contract, and that the protection of the nonforfeiture statute could not be waived by stipulations in the policy. While the decision is a routine one applying the law of the place of contracting, it is consistent with recognition of the interest of Missouri-the forum, in post-Erie terminology-in protecting its residents, and it is worthy of note that both the Supreme Court ${ }^{108}$ and the circuit court ${ }^{109}$ took occasion to emphasize the policy embodied in the statute.

The next case which requires mention did not involve a question of choice of law at all; but it is relevant to a suggestion which is sometimes advanced, ${ }^{110}$ that the power of a state in Missouri's position in cases of this general type is to be rested on the power to exclude foreign corporations, or to regulate the terms on which they may do business, rather than on an analysis of governmental interests. We shall have occasion to examine this suggestion in detail at a later stage, and it is well to notice the relevant materials in chronological order. The Missouri nonforfeiture statute which has been under discussion purported to apply only to policies issued by companies authorized to do business in the state. ${ }^{.11}$ That fact, coupled with the power to exclude, did not secure the application of Missouri law in Dodge; nor did it facilitate the application of Missouri law in Liebing. It was not relied on by the Court to bolster the application of Missouri law in Clements. In Orient Ins. Co. v. Daggs, ${ }^{112}$ the Court had to consider a different Missouri statute, this time relating to fire insurance, and this time not limited to policies issued by licensed companies. In effect, the statute converted all fire insurance policies into valued policies, precluding the defendant from denying that the property was worth, at the time of issuance of the policy, the full amount for which the property was insured. Here the property was located in Missouri, and the company was a Connecticut corporation authorized to do business in the state. The policy purported to limit liability to the actual cash value at the time of the fire. No contention was made that the law of Connecticut governed; the due-process attack was on more familiar grounds, and asserted that the statute deprived the parties of liberty of contract in precisely the same terms that would have been employed had the transaction been a wholly domestic one. The Court sustained the enactment as a reasonable exercise of the police power. In a rather confused context, the company urged that compliance with the statute was not made a condition of the right of a foreign corporation to transact business locally. The Court responded that the Missouri Supreme Court had held the contrary, and continued:

But we do not care to enter fully into the subject of conditions on corporations, foreign or domestic. The statute is sustained on the grounds that we have given. ${ }^{113}$

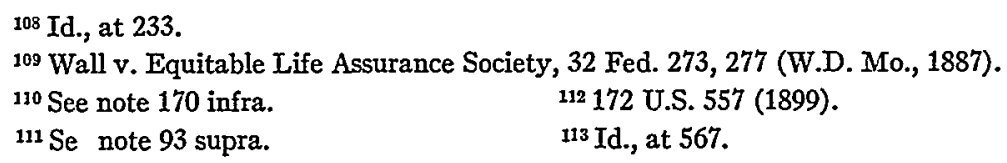


The Missouri statute prohibiting forfeiture of life insurance policies came before the court again in New York Life Ins. Co. v. Cravens. ${ }^{114}$ Here the policy was issued on the life of a Missouri resident by a New York corporation, licensed to do business in the state. The application contained a provision that "the contract contained in such policy and in this application shall be construed according to the laws of the State of New York, the place of said contract being agreed to be the home office of said company in the citv of New York."115 The issue was whether the insured was entitled to full coverage for a term, as provided by the Missouri statute, or to paid-up insurance at a lower figure as provided by the policy consistently with the law of New York. It is worth noting that the Court did not inquire at all into the question of where the contract was made, although the facts were so similar to those in Clements that the Court might simply have cited that case as authority for the proposition that it was made in Missouri. ${ }^{116}$ The Missouri court had upheld the statute as a condition of the right of foreign insurance companies to do business in the state. The Supreme Court affirmed on the same ground. The decision did not overlook the doctrine of unconstitutional conditions. Mr. Justice McKenna was careful to point out that the statute bore a reasonable relation to the governmental interests of the state. The company argued for the principle of autonomy, which permits the parties to choose the applicable law in an "interstate contract," and asserted that the stipulation for New York law was " in nowise prejudicial to the interests of the state of Missouri or violative of its public policy." "117 The Court replied:

But the interests of the State must be deemed to be expressed in its laws. The public policy of the State must be deemed to be authoritatively declared by its courts. Their evidence we cannot oppose by speculations or views of our own. Nor can such interests and policy be changed by the contract of parties. Against them no intention will be inferred or permitted to be enforced.118

The Court went on to quote what had been said in Clements by way of stating the policy embodied in such statutes, and concluded by pointing out that in the Daggs case the Court had sustained the valued-policy statute independently of the ground that it was a condition of the right of foreign corporations to do local business. "We sustained it on the ground of the clear right of the State to pass it, and to accomplish its purpose by limiting the right of the insurer and insured to contract in opposition to its provisions." "119 The clear inference was that the same ground would suffice in the case before the Court, the state having a clear policy and a clear interest in its application.

The Cravens case is also significant because the company made a strong plea

I14 178 U.S. 389 (1900).

${ }^{115}$ Id., at 392.

${ }^{116}$ That is, it might have done so if it had been prepared at that time to hold that the same rule which it applied for choice of law in a diversity case was decisive in a case presenting a constitutional question.

117178 U.S. 389, 398 (1900). $\quad{ }^{118}$ Ibid. $\quad{ }^{119}$ Id., at 399. 
for the "necessity" of a uniform law, pointing out that it was "the administrator of a fund collected from the policy holders in different States and countries for their benefit." 120 It was not sufficiently bold, or imaginative, to claim, as later became the fashion, ${ }^{121}$ that universal deference to the law of the state of incorporation, enforced by the Full Faith and Credit Clause, was the royal road to attainment of the desired uniformity; its more modest contention, that the parties should be free to stipulate for the uniform application of the law of New York, was easily answered by the Court's observation that this would give an advantage to foreign companies, since Missouri companies (at least in their dealings with Missouri residents) could not escape the Missouri law by such a device. ${ }^{122}$

The next case, New York Life Ins. Co. v. Head, ${ }^{123}$ is one of crucial importance. The insured was a resident of New Mexico at all relevant times, as was the beneficiary; but the policy was applied for and delivered in Missouri under circumstances which, according to the Court's prior decisions, made it a Missouri contract, and the Court assumed that this was so. ${ }^{124}$ In 1904 a policy loan was negotiated by correspondence between New Mexico and New York. This, it should be remembered, was after the Missouri statute was amended to allow deduction of all policy loans from the net value; strangely, however, the case contains no reference whatever to the amendment, and, for all that appears, the Court may have been unaware of it. Neither in the reported arguments of counsel nor in the opinion of the court below is there any mention of the amendment. ${ }^{125}$ Upon lapse, the policy was commuted to paid-up insurance in a small amount in accordance with its terms and with the law of New York; the action was predicated on the fact that the reserve was sufficient, under the (original) Missouri statute, to continue the insurance in force at face value for a term extending beyond the death of the insured. The unanimous Court, through Chief Justice White, held the statute as applied a denial of due process on the ground that, since neither the insured nor the beneficiary was a resident of Missouri, that state had no interest in the application of its nonforfeiture policy. The Cravens case was distinguished on the ground that it concerned insurance on the life of a citizen of Missouri. ${ }^{126}$ The Court denied the power of the state where a

${ }^{120} \mathrm{Id}$., at 400.

122 New York Life Ins. Co. v. Cravens, 178 U.S. 389, 400 (1900).

${ }^{123} 234$ U.S. 149 (1914).

${ }^{124}$ The Court's language was significant: “. . . we pass the consideration of the ruling below holding that under the proof the contract was a Missouri contract and therefore for the sake of argument only concede that there was power in the State to treat the contract made for the purposes stated as a Missouri contract and to subject it as to matters and things which were legitimately within the state authority to the rule of the state law." Id., at 160 (italics added).

${ }^{125}$ See Head v. New York Life Ins. Co., 241 Mo. 403, 144 S.W. 16 (1912).

${ }^{126} \mathrm{New}$ York Life Ins. Co. v. Head, 234 U.S. 149, 160, 162 (1914). The Court also referred to the fact that the contract of insurance in Cravens was made in Missouri; but so was the contract of insurance here. Therefore the only distinguishing feature was the residence. 
contract is made to "affect the parties to such original contract with a perpetual contractual paralysis. ..."127 It rejected the contention that the application of Missouri law could be justified on the basis of the power of the state to exclude foreign corporations, equating the Due Process Clause with the Full Faith and Credit Clause as a source of the principle that a state has no power to regulate the "domestic concerns" of other states. ${ }^{128}$ The Court gave almost no weight to the fact that the loan agreement was clearly not made in Missouri, as is shown by the fact that it declined to consider whether that agreement was "subsidiary" to the policy. ${ }^{129}$ The decision is in striking opposition to the territorialist theory of vested rights, at least in so far as that theory selects the making of the contract as the factor which legitimizes the exercise of territorial power; it furnishes strong support for the view that the applicability of a state's law is to be determined according to whether or not the state has a legitimate interest in the application of its governmental policy..$^{130}$

If the place where the loan agreement was made was immaterial in Head, it was equally so in Dodge and Liebing. In all three, according to the principle of the Head case, the legitimacy of Missouri's interest could be determined without reference to that factor, simply by inquiring whether the persons protected were within the legitimate scope of the state's protective policy. Indeed, we knowbut we cannot charge the Court with knowledge, because it was inadequately informed - that the place where the loan agreement was made was immaterial in all three cases. Since all three loan agreements were made after the nonforfeiture statute had been amended, the plaintiffs could not have derived the rights they claimed from those agreements. Whatever rights they claimed by virtue of the original nonforfeiture statute must be derived through the original policy, which was the only contract made while that statute was in force. ${ }^{131}$ Hence all the fine-

${ }^{227}$ Id., at 161.

${ }^{128}$ Id., at $161,163$.

${ }^{129}$ Id., at 165 . Cf. note 131 infra.

${ }^{130} \mathrm{It}$ is important to observe that the Court obviously did not feel that, in limiting its protective policy to residents of the state, who alone were within the scope of its legitimate concern, Missouri would violate either the Equal Protection Clause or the Privileges and Immunities Clause. Cf. Quong Ham Wah Co. v. Industrial Accident Commission, 184 Cal. 26, 192 Pac. 1021 (1920), writ of error dismissed 255 U.S. 445 (1921). The possibility of such a problem could hardly have escaped the Court's attention, since the Missouri Supreme Court had emphasized the altruistic purpose of the legislature to extend the protection of its policy to "all persons whether citizens, inhabitants, transients, visitors or sojourners," Head v. New York Life Ins. Co., $241 \mathrm{Mo} .403,416,147$ S.W. 827, 831 (1912), and counsel for the plaintiff had suggested the point of unconstitutional discrimination in the Supreme Court. See New York Life Ins. Co. v. Head, 234 U.S. 149, 152 (1914).

${ }^{131}$ No case has been found in which the Missouri court held explicitly that the 1903 amendment did not cut off the "right" of the insured, under a policy previously issued, to obtain loans on the terms specified in the statute. (Of course, it so held by implication in each of the three cases involving loans after the amendment.) The closest approximation to direct consideration of the question is the statement in the Head case that " $\mathrm{Tt}$ is not an open question ... that all subsidiary contracts made by the parties to an insurance contract are within the contemplation 
spun arguments in Dodge and Liebing concerning the place where the loan agreements were made were to no purpose whatever. A good territorialist, aware of the amendment and of the fact that the real foundation of the plaintiff's claim must be the original policy, would have applied the law of the state where the policy contract was made-clearly Missouri. Holmes almost certainly knew of the amendment; perhaps bis decision can be explained on the ground that he wished to hold applicable the law of the state where the only relevant contract was made. ${ }^{132}$ At any rate, both $H e a d$ and Dodge denied the constitutional power of that state to apply its law-because it had no real interest.

Mr. Justice McReynolds in the Dodge case relied heavily on Head. His argument is, on the surface, no more than a denial of the power of Missouri to control a contract made outside the state. Read against the background of the earlier cases, however, the opinion seems to be an attempt to make this point: that, just as Missouri could not, merely because it was the place where the original contract was made, fix for all time the rights of the nonresident parties in such manner that they could not be altered by subsequent agreement, so also Missouri could not, merely because it was the place where the original contract was made, fix the rights of the parties in such manner that they could not be altered by subsequent agreement at a time when Missouri no longer adhered to its protective policy. The point may be stated in this way: A state is justified in applying its law when there is a concurrence of two conditions. First, there must be an ascertainable policy, suitably expressed in the law of the state. Second, the relationship of the state to the parties, the transaction, the subject matter, or the action must be such as to give the state a legitimate basis for an interest in the application of its policy in the circumstances; the matter must be within the scope of the state's legitimate governmental concerns. In the Head case the Court held, quite properly, that the state had no legitimate interest in the application of its policy to nonresidents. In the Dodge case, it is equally clear that the Missouri court's decision was erroneous since, although the insured and the beneficiary were Missouri residents-a fact which would support the application

and puryiew of the original contract, and are not to be treated as independent agreements." Head v. New York Life Ins. Co., 241 Mo. 403, 418, 147 S.W. 827, 832 (1912). But of the two cases cited following this statement, one was decided before the amendment (it was, in fact, the decision which precipitated the amendment), Smith v. Mutual Benefit Life Ins. Co., $173 \mathrm{Mo}$. 329,172 S.W. 935 (1903), and the other merely holds that the amendment did not operate retrospectively to affect rights under a loan agreement made prior to its passage. Burridge $v$. New York Life Ins. Co., 211 Mo. 158, 109 S.W. 560 (1908).

${ }^{132}$ In fact, the Dodge and Liebing cases have been interpreted as treating the question of offer and acceptance not for the purpose of determining where the loan agreements were made but in order to determine whether they were independent of, or subsidiary to, the policies. Aetna Life Ins. Co. v. Dunken, 266 U.S. 389 (1924), discussed infra at note 136. But a finding that they were subsidiary, while implying that the insured was entitled to obtain a loan simply on demand, falls considerably short of a determination that such a loan must embody all the provisions of statutes in force when the policy was made, where those provisions are altered before the loan is demanded. 
of a local protective policy-the state had, at the time the loan agreement was made, no such policy as was invoked and applied.

Between the times when the Dodge and Liebing cases were decided, the Court rendered its unanimous decision in American Fire Ins. Co. v. King Lumber $\mathrm{Co}^{133} \mathrm{~A}$ Florida statute in effect made insurance brokers agents of the underwriting company. When the Florida court applied this statute to insurance procured by a Florida broker from a Pennsylvania company to cover property in Florida, the company, complaining that the policy was a Pennsylvania contract, appealed. The Court did not even bother to inquire where the contract was made. ${ }^{134}$ Nothing in the statute, in the situation of the company, nor in the opinion of the court suggests that the doctrine of conditions on the right of foreign corporations to carry on business was a factor in the case. The decision proceeded on the forthright ground of the clear interest of Florida in regulating insurance on local property:

The Florida statute does not attempt to invade Pennsylvania and exercise control there. It stays strictly at home in this record and regulates the insurance company when it comes to the State to do business with the citizens of the State and their property. ${ }^{135}$

As a guardian of the constitutional status of the place of making, Aetna Life Ins. Co. v. Dunken, ${ }^{136}$ also has more bark than bite. A convertible term policy was written on the life of a resident of Tennessee by a Connecticut company. The insured moved his residence to Texas, and thereafter exercised his option to convert to a different form of policy. Asserting defenses which are not material here, the company refused to make payment on demand, and the plaintiff was successful in his action. A Texas statute prescribed a penalty of 12 per cent of the recovery, together with reasonable attorney's fees, for failure to pay claims within thirty days of demand, and the judgment for the plaintiff included both. The unanimous Court, speaking through Mr. Justice Sutherland, held that the conversion transaction was subsidiary to-in fact, a consummation of-the original policy, which was a Tennessee contract; that the place of issuance of the new policy was irrelevant; that Tennessee law governed; and that application of the Texas law was a denial of full faith and credit to the laws of Tennessee. ${ }^{137}$

133250 U.S. 2 (1919).

${ }^{134}$ It might have decided the case on this ground, since the court below had held the contract was made in Florida. See id., at 14.

${ }^{135} \mathrm{Id}$., at 12. The Court disposed of the argument invoking the Full Faith and Credit Clause by saying that there was no Pennsylvania law to the contrary. Id., at 10 .

136266 U.S. 389 (1924). For a contemporary comment, see Federal Review of Errors of State Courts under the Full Faith and Credit Clause and the Fourteenth Amendment, 38 Harv. L. Rev. 804 (1925).

${ }^{137}$ No relevant statute of Tennessee was cited. The Court did not discuss the fact that the Texas statute purported to make the provisions conditions of the right of foreign companies to do business in the state, although it appeared that Aetna was licensed in Texas. See 69 L.Ed. 342,345 (1924). The conversion of the policy was effected through the company's agent in Tennessee. 
The opinion of the Court is devoted almost entirely to the question whether the conversion transaction was "subsidiary" to the original policy or an "independent" agreement.

We may, first of all, agree wholeheartedly with the Court that the conversion was merely an incident of the original policy. This, however, does not solve the problem, as the Court supposed; it merely states it in such a way as to facilitate its solution. In order to make the problem perfectly clear, let us assume that no conversion was involved, but that the insured simply moved from Tennessee to Texas, taking with him a life insurance policy issued to him in Tennessee. ${ }^{138}$ This is, in substance, the actual situation as the Court saw it. Now, Texas may constitutionally adopt a policy of securing prompt payment of insurance claims by imposing penalties for delay. This is the teaching of the cases which upbeld the statute, in its application to wholly domestic transactions following its enactment, against ordinary attacks based on the Due Process Clause. ${ }^{139} \mathrm{It}$ has a legitimate interest in the application of that policy where the persons protected are within the ambit of the state's governmental concern. Could Texas, however, apply that policy to insurance contracts concluded prior to the date of the enactment, even if they were made locally on the lives of local residents? ${ }^{140}$ If not, it follows that the Court was right in denying to Texas the power to apply the statute to a contract which, while made after the statute was enacted, was made in such circumstances that Texas then had no interest in the application of its protective policy. The retrospective application of the statute would be condemned (if at all) for the reason that at the time the contract was made Texas had no such protective policy as the statute embodied, and hence had no interest in applying its law in such a way as to alter materially the obligation assumed by the company. But it is equally true that Texas, while it had announced the protective policy before the Dunken policy was issued, had no interest in the application of that policy to protect a resident of Tennessee not similarly protected by his home state..$^{141}$ On the other hand, if the statute is regarded as a reasonable exercise of the power of Texas to regulate the future conduct of insurance companies in settling claims, rather than as a prohibited enlargement of the obligation assumed by the company, Texas has an interest in the application of its policy for the protection of all Texas residents, whether their policies were issued before the enactment or not, and whether or not their policies were issued prior to the time when they became Texas residents. If, for example, the

${ }^{138}$ The Head and Dodge cases, with their denial of the power of the state of the original policy to afflict the parties with "a perpetual contractual paralysis," are not relevant here. Those cases related to the freedom of the parties to modify the original policy by agreement, while the case under discussion concerns the power of Texas to affect it by statute.

${ }^{139}$ See the cases collected in 14 Tex. Civ. Stat. Ann. (Vernon, 1952) Art. 3.62.

${ }^{140}$ Cf. Funkhouser v. J. B. Preston Co., 290 U.S. 163 (1933); Pacific Mutual Life Ins. Co. v. Berryhill, 69 S.W.2d 784 (Tex. Civ. App., 1934); Hale, The Supreme Court and the Contract Clause, 57 Harv. L. Rev. 512, 621, 852 (1944).

${ }^{141}$ Cf. Home Ins. Co. v. Dick, 281 U.S. 397, 411 (1930). 
Texas statute had provided merely for interest on the obligation from the date of demand, whereas Tennessee law specified interest only from the date of judgment, it is probable that application of the Texas statute to domestic contracts made before its enactment would be upheld. ${ }^{142}$ It is equally probable that the Court, in such a case, would not have held that the Texas statute could not be applied to the contract which Dunken took with him from Tennessee to Texas. This is true despite the fact that the logic of the Court's opinion would require a contrary result: if the policy was a Tennessee contract, governed by the law of Tennessee, and if the Full Faith and Credit Clause requires the application of Tennessee law, then Texas' law concerning interest can no more be applied than its law imposing a penalty. ${ }^{143}$ In short, once we rid the case of the irrelevant circumstance that the conversion took place after Dunken moved to Texas, it is abundantly clear that the case does not present a problem of choice of law, at least in the usual sense, at all. Texas could not plausibly assert any claim whatever for the application of its statute to a policy issued by a Connecticut corporation to a resident of Tennessee in Tennessee. ${ }^{144}$ The simple truth is that the only constitutional question involved was one of impairment of the obligation of contracts; the essential problem concerns the temporal application of the statute, not its territorial application.

The next case to be considered is the familiar one of Home Ins. Co. v. Dick. ${ }^{145}$ It furnishes strong support for the thesis that when a state having no interest in the matter applies its law to the exclusion of the proffered law of an interested foreign state, due process is denied. A marine insurance policy was issued by a Mexican company in Mexico to a resident of Mexico. It covered the vessel only in certain Mexican waters, and losses were payable in Mexico City. The policy contained a provision, valid under Mexican law, limiting actions to one year from the occurrence of damage. ${ }^{146}$ Prior to the loss the policy was assigned to the plaintiff, Dick, then a resident of Mexico though domiciled in Texas. Dick brought his action against the insurer in the Texas courts, ${ }^{147}$ which held the contractual limitation was invalidated by a Texas statute which provided (in typically general terms):

${ }^{142}$ Cf. Funkhouser v. J. B. Preston Co., 290 U.S. 163 (1933).

${ }^{143}$ Confronted with a case such as has been supposed, the Court would probably have justified application of the Texas statute on the ground that it related to a matter of "procedure," governed by the law of the forum. Cf., Klaxon Co. v. Stentor Electric Mfg. Co., 313 U.S. 487 (1941).

144 Except, of course, on the assumption stated above, that the statute was a reasonable regulation of the future conduct of an insurer of local residents.

${ }^{145} 281$ U.S. 397 (1930).

${ }^{146}$ The period of limitation prescribed by the Mexican Commercial Code was apparently the same. See id., at 403 n.1, 404 n.3.

${ }^{147}$ Two New York companies, licensed to do business in Texas, had reinsured parts of the risk-a factor which seems immateral except as explaining how the action against the Mexican insurer was maintained in Texas. Personal service on the insurer being impossible, the reinsurers were summoned as garnishees. 
No person, firm, corporation, association or combination of whatsoever kind shall enter into any stipulation, contract, or agreement, by reason whereof the time in which to sue thereon is limited to a shorter period than two years. And no stipulation, contract, or agreement for any such shorter limitation ... shall ever be valid in this State. ${ }^{148}$

The Supreme Court held the application of the Texas statute a denial of due process of law. The decision supports the thesis of this paper since Texas had no legitimate interest in the application of its law and policy. The technical domicile of the plaintiff in that state cannot support the assertion of an interest since he was a mere assignee of the contract. It is true that the opinion by Mr. Justice Brandeis has a strongly territorialist flavor, but it is hardly true that the decision is fully consistent with conventional territorial theory, for that theory in general concedes to the forum the power to apply its own "procedural" laws, including statutes of limitation. This much was acknowledged by Brandeis, who distinguished this case on the ground that the Texas statute did not deal with procedure but with lawful and unlawful agreements, and further on the ground that a foreign contract rather than a foreign statute of limitations was involved. The distinctions are unconvincing. Mr. Justise Brandeis himself left open the question whether, if a foreign statute "extinguished" the right instead of merely barring the remedy, a state would be justified in applying a local statute prescribing a longer period..$^{149}$ Indeed, a recent decision of the Court of Appeals for the Second Circuit, refusing to recognize the bar of the Panamanian statute of limitations in an action predicated upon the Panamanian Labor Code, seems clearly to be as much a violation of due process as the decision of the Texas courts in the Dick case, for all that appears in the reported facts; for there is nothing whatever to indicate that the United States had any basis for an interest in the application of any policy allowing a longer time to sue..$^{150}$

Hartford Accident \& Indemnity Co. v. Delta \& Pine Land Co. ${ }^{151}$ also concerns a contractual time limitation, but is thoroughly inconsistent with the thesis advanced here. The plaintiff, a Mississippi corporation with offices in Tennessee, obtained from the defendant, a Connecticut corporation also doing business in both Tennessee and Mississippi, a policy insuring against defalcations by its

148 Home Ins. Co. v. Dick, 281 U.S. 397, 404-5 (1930). ${ }^{49} \mathrm{Id}$., at 409 , n.7.

${ }^{150}$ Bournias v. Atlantic Maritime Co., 220 F.2d 152 (C.A.2d, 1955). The decision below is reported at 117 F.Supp. 864 (S.D.N.Y., 1954). See, Specificity Test as Exclusive Criterion Bars Application of Foreign Statute of Limitations, 55 Col. L. Rev. 1072, 1075 (1955); cf. Lauritzen v. Larsen, 345 U.S. 571 (1953); Gilmore and Black, The Law of Admiralty 388, n.414 (1957). The record discloses that the plaintiff was a Greek national, Transcript of Record at 19; that the voyages for which he signed were to begin and end in the United States, id., at 5; that he was discharged in New York, id., at 19; and that more than a year after his discharge he made a technical re-entry into the country for the purpose of becoming a legal resident, id., at 73-74. There is no information available as to the nationality of the beneficial owners of the vessel. though an inference that they were Greek also might find some hint of support. Id., at 79 et seq.

151292 U.S. 143 (1934). 
treasurer. The contract was concededly made in Tennessee. It specifically insured against acts of dishonesty by covered employees "in any position, anywhere." The treasurer, who when the policy was issued was stationed in Tennessee, moved to Mississippi, and his defalcations occurred there. Action on the policy was defended on the ground that the plaintiff, though acting promptly on discovery of the employe'e's misconduct, had not made claim within fifteen months of the termination of the insurance coverage, as required by a provision of the policy valid under the law of Tennessee. ${ }^{152}$ The Mississippi court held the contractual limitation inoperative under a Mississippi statute providing:

The limitation prescribed in this chapter shall not be changed in any way whatsoever by contract between parties, and any change in such limitations made by any contract stipulation whatsoever shall be absolutely null and void; the object of this statute being to make the period of limitations for the various causes of action the same for all litigants. ${ }^{153}$

Other provisions of Mississippi law, as construed by the state court, made this provision applicable to insurance on "or concerning any property or interest or lives in this state, or with any resident thereof. . . ."154 The Supreme Court, Mr. Justice Roberts writing the opinion, reversed on the ground that the statute as applied was a denial of due process. Mississippi could not "extend the effect of its laws beyond its borders so as to destroy or impair the right of citizens of other states to make a contract not operative within its jurisdiction, and lawful where made."155 For these propositions the Court cited Head and Dunken. But was not the insured here a Mississippi corporation? The Court answered that under the Dick case the state could not predicate an interest solely upon the fact that one of the parties was its citizen. But this is a distortion of the holding in the Dick case. There the citizen of Texas was not a party to the contract, but only an assignee. ${ }^{156} \mathrm{Did}$ not the loss which was insured against occur in Mississippi, and did not the contract contemplate payment there? Although the Court spoke of governmental interests, it treated this as an argument that Mississippi might apply its law as that of the place of performance, and, proceeding to compare the "relative importance of the interests of the forum as contrasted with those created at the place of the contract...," concluded that there was a

${ }_{152}$ It will be observed that this is not quite the same thing as a specification of the maximum time which may elapse between the accrual of a cause of action and the commencement of action. So far as can be judged, however, the difference is immaterial.

${ }^{153}$ Hartford Accident \& Indemnity Co. v. Delta \& Pine Land Co., 292 U.S. 143, 148 (1934). $154 \mathrm{Id}$, at 147. ${ }^{155} \mathrm{Id}$., at 149.

${ }^{156}$ Moreover, since he was a resident of Mexico, his domicile in Texas was nominal only. It may be conceded that the state's basis for asserting an interest can become so attenuated as to justify its disregard. See Grubel v. Nassauer, 210 N.Y. 149, 103 N.E. 1113 (1913); cf. McDonald v. Mabee, 243 U.S. 90 (1917). But domicile or residence in fact (not of "one of the parties" but of the party whose residence is significant) is a recognized basis for the assertion of state power or policy in many instances. Milliken v. Meyer, 311 U.S. 457 (1940); Griffin v. McCoach, 313 U.S. 498 (1941); cf. Union Trust Co. v. Grosman, 245 U.S. 412 (1918). 
denial of due process because Mississippi had "but slight connection with the substance of the contract obligations." 157 The thesis of this paper can derive no support from the Court's employment of the concept of governmental interest, since it treats the interest of Mississippi as being predicated on such artificialities as the place of payment rather than on incidents which realistically warrant the application of policy - and, moreover, because it begs the question by treating the opposing interest as being not that of Tennessee but that of the insurance company, based on the "applicable" law of Tennessee.

One gets the impression that the Court was influenced by the fact that, just as Mr. Dunken had moved from Tennessee to Texas after taking out life insurance, so here the treasurer moved from Tennessee to Mississippi after his employer took out fidelity insurance. But surely the differences are significant. Here the insured was a Mississippi corporation, as the insurer well knew. The contract expressly contemplated that the treasurer-not to mention other employees within the policy's coverage - would be employed in Mississippi, and undertook to indemnify against misconduct anywhere. The misconduct occurred in Mississippi. It cannot be said that Mississippi had no interest in the application of its policy until the treasurer entered the state.

John Hancock Mutual Life Ins. Co. v. Yates ${ }^{158}$ is similar to the Dunken case, in that the insurance policy was issued under circumstances which could not conceivably give the forum any interest in the application of its governmental policy regarding the business of insuring lives. The policy was applied for and delivered in New York, where the insured and the beneficiary both resided, and where the insured died. The widow moved to Georgia and there brought action on the policy. The defense, which was iron-clad under New York statutes as construed by the New York courts, was that the application contained material misrepresentations. The Georgia court, though professing to recognize that the contract was governed by New York law, applied Georgia precedents which permitted the jury to find that the insured had answered the questions in the application truly, but that the agent had written false answers; that the knowledge of the agent was imputed to the company; and that the misrepresentations were not "material." This deviation from New York law was justified on the ground that such matters related to the remedy, or mode of procedure, and were determinable by the law of the forum. Mr. Justice Brandeis gave this argument deservedly short shrift, holding that the Georgia court had denied full faith and credit to the laws of New York.

It is manifest that Georgia had no interest in the application to this case of any policy to be found in its laws. When the contract was entered into, and at all times until the insured died, the parties and the transaction were beyond the legitimate reach of whatever policy Georgia may have had. Any interest as-

157 Hartford Accident \& Indemnity Co. v. Delta \& Pine Land Co., 292 U.S. 143, 150 (1934).

158299 U.S. 178 (1936). 
serted by Georgia must relate to the circumstance that the action is tried there, and must arise not from any policy directed to the business of life insurance but from some policy having to do with the business of the courts. This was apparently recognized even by the Georgia court; hence the disingenuous characterization of the matter as one of "procedure" rather than of "substance." What was not recognized was that Georgia had no such policy relating to the administration of its courts as would permit the assertion of an interest in the application of the laws that were applied. Of course, the forum is not required by the Full Faith and Credit Clause, nor the Due Process Clause, nor the Contracts Clause $^{159}$ to apply every jot and title of the proper foreign law to the exclusion of its own; but its application of local law in a case such as this must find reasonable justification in a relevant policy. The application of New York law here would have caused the Georgia court no such inconvenience as is contemplated by the doctrine favoring the law of the forum in procedural matters. ${ }^{160}$ Nor could it have interfered in any conceivable way with any Georgia policy concerning administration of its courts. The decision could mean only that Georgia differed with New York with respect to the regulation of life insurance transactions, and applied its own views to a transaction with which it had no concern.

The celebrated case of Griffin v. McCoach ${ }^{161}$ also contains a ruling on the propriety of a choice of law in terms of the Due Process Clause or the Full Faith and Credit Clause- a fact which is in some danger of being obscured by the highly controversial holding concerning the source of rules for choice of law in diversity cases in the federal courts. The ruling was that, even assuming that the insurance transactions were New York contracts, "valid" under New York law, Texas could constitutionally refuse enforcement of rights asserted under them on grounds of local public policy, the insured being a citizen of Texas; and, according to the more familiar holding, what the Texas court would constitutionally do, the federal court sitting in Texas must also do in the interpleader proceeding. ${ }^{162}$ For the time being we shall defer consideration of the case in so far as it bears on the function of federal courts with respect to choice of law in diversity cases. ${ }^{163}$ For present purposes, the case has special significance in two ways:

(1) It drives a stake through the heart of the Brandeis fallacy. ${ }^{164}$ That is to say, the decision cannot be explained in territorialist terms on the ground that, while New York law "governed," Texas was free to refuse enforcement to the

${ }^{159}$ Cf. the analysis of Aetna Life Ins. Co. v. Dunken, 266 U.S. 389 (1924), in terms of impairment of the obligation of contracts.

${ }^{160}$ See Rest., Conflict of Laws c. 12, Introductory Note (1934); Cook, "Substance" and "Procedure" in the Conflict of Laws, 42 Yale L. J. 333 (1933).

161313 U.S. 498 (1941).

${ }^{362}$ Id.,at 504 et seq. See also the decision of the Court of Appeals on remand, 123 F.2d 550 (C.A.5th, 1941).

${ }^{163}$ See note 332 infra. ${ }^{164}$ See note 85 supra. 
rights thereby created because in so doing it did not impair the substantive rights of the assignees, but left them free to pursue their remedy elsewhere. This was an interpleader proceeding, and the result was a judgment on the merits awarding the proceeds of the policy to the administrator as against the assignees. Thus the decision clearly confirms the conclusion that the measure of a state's right to apply its "local public policy" is the same as that of its right to apply its "law": a legitimate interest in the application of its governmental policy is required, and is all that is required, in either case.

(2) It reinforces our conclusion that the Supreme Court, in reviewing state court decisions on choice of law, will not "weigh" the conflicting interests of the states concerned but will inquire no further than is necessary in order to ascertain that the state whose law is applied has a legitimate interest in its application. This aspect of the case is somewhat obscured by the fact that the Court was reviewing the decision of a lower federal court in a diversity case; nevertheless, with respect to this branch of the decision, the Court was performing the same function that it performs when reviewing the decision of a state court: it was deciding whether Texas could apply its law consistently with the Due Process and Full Faitb and Credit clauses. If the Court does possess the power to determine the relative merits of the conflicting state policies, this case, above all others, should have called forth its exercise. Texas stood alone among all the states in its "cynic fear"165 that the lives of its citizens would be endangered unless an insurable interest were required of beneficiaries and assignees, even though the insured himself procured the insurance; ${ }^{165}$ some indication that the policy of Texas was a vestigial one is afforded by the fact that within a few years it was changed by statute; $;^{167}$ and the "reasonable expectations" of the assignees cried aloud for vindication.

The capstone of the argument is supplied by Watson v. Employers Liability Insurance Corp. ${ }^{168}$ So explicit is the Court's analysis in terms of state interests and its rejection of territorialist dogma that any interpretation seems superfluous. ${ }^{169}$ The significance of the case is best appreciated through study of the concurring opinion of Mr. Justice Frankfurter, who plainly had deep misgivings about the interest analysis and who sought to avoid a decision on constitutional grounds. He would have rested the decision on the ground that Louisiana, in the

${ }^{165}$ See Grigsby v. Russell, 222 U.S. 149, 156 (1911).

${ }^{166}$ See Carnahan, Conflict of Laws and Life Insurance Contracts 340 (2d ed., 1958), and authorities there cited.

${ }^{167}$ See 14 Tex. Civ. Stat. Ann. (Vernon, 1952) Art. 3.49; id., Art. 3.49-1 (Supp., 1958).

${ }^{168} 348$ U.S. 66 (1954).

${ }^{169}$ Specific mention may be made, however, of (1) the statement of the basis for Louisiana's interest in protecting persons injured there, id., at 72-3; (2) the treatment of the Full Faith and Credit Clause as having substantially the same function as the Due Process Clause for the purposes under discussion, id., at 73; and (3) the recognition that Massachusetts also had an interest in the application of its contrary policy ("[B]ut plainly these interests cannot outweigh the interest of Louisiana...."), id., at 73. 
exercise of its power to exclude the foreign insurance company from doing business in the state, lawfully obtained the company's actual consent to the terms of the direct-action statute. But this device failed to avoid a constitutional question, or even to change the ultimate constitutional issue. For Mr. Justice Frankfurter was, of course, confronted by the problem of "unconstitutional conditions"; and in the end his own analysis demonstrated that, to avoid the stigma of unconstitutionality, a condition exacted of a foreign corporation as the price of the privilege of doing business must meet "the standard of reasonableness."170 The same considerations which had led the majority to conclude that Louisiana had a legitimate basis for the application of its policy, so that there was no denial of due process nor of full faith and credit, led him to conclude that Louisiana had a reasonable basis for imposing the condition:

It meets the test of reasonableness because the conditions imposed are fairly related to the interests which Louisiana may appropriately protect in surrendering its right to exclude a foreign corporation. The interests of Massachusetts or Ilinois do not so obviously subordinate those of Louisiana that the latter must constitutionally yield to the former. ${ }^{171}$

This, together with our review of the earlier cases, should set to rest any idea that the power to exclude plays a distinctive role in the analysis of this problem. When the Court has upheld the right of a state to apply its own law, it has sometimes thrown in the power to exclude as a makeweight argument; but when it has denied that right, the power to exclude has not availed the state. Whether the issue is cast in terms of due process and full faith and credit or in terms of the power to exclude, the test is the same: Does the state have a legitimate interest in the application of its policy?

The prime significance of the concurring opinion lies in the fact that it is a rear-guard defense of traditional conflict-of-laws theory against the analysis in terms of state interests and its assumed implications. If we ask what Mr. Justice Frankfurter would accomplish by his proposed treatment of the case, we may fairly answer:

(1) He would limit the effect of the decision to cases in which the foreign corporation actually consents, leaving open the case in which the defendant is not licensed to do business locally; ${ }^{172}$

(2) He would-at least hopefully-escape any direct inroad upon conflict-oflaws principles which deny Louisiana the right to "apply its law" to "modify" a foreign contract (Louisiana is somehow not applying its law, but only entering into a sort of contract with the company);

(3) He would avoid the apprehended necessity of weighing, or balancing, the competing interests of Massachusetts and Louisiana. When the problem is

${ }^{170} \mathrm{Id}$., at 82. 171 Id., at 82-3.

172 In addition, without explaining why, he speaks always of Louisiana's interest in protecting its own "citizens," implying unwillingness to follow the majority in conceding the state an interest in protecting any person injured within its borders. 
stated in terms of the reasonableness of a condition of the right to carry on business, it is enough, it seems, to find that Louisiana has an interest, or at least that its interest is not "obviously" subordinate to that of the other state. ${ }^{173} \mathrm{Mr}$. Justice Frankfurter was keenly aware of the fact that Massachusetts likewise had interests at stake in the case before the court; his statement of them is a model for those of us who would inquire into such matters. ${ }^{174} \mathrm{He}$ felt that the majority was ignoring those interests. In the light of the fact that the majority expressly conceded them, ${ }^{175}$ this feeling must have been premised on the view that recognition necessarily involves evaluation and choice. Understandably, Mr. Justice Frankfurter shrank from undertaking such an evaluation: "Realization that the Louisiana statute . . . raises the delicate problem of balancing interests - that refractory aspect of due process-admonishes its avoidance when an easier solution lies at hand."176 The problem of balancing interests is delicate and refractory indeed, because it is a legislative problem. But the majority did not ignore the interests of Massachusetts, nor did it feel compelled to weigh them against those of Louisiana and make a choice. Nothing in the opinion implies that the Louisiana statute would be controlling if the action were brought in Massachusetts; on the contrary, the implication is that Massachusetts would

- be similarly free to advance its own interests. The refusal of the majority to weigh the interests of Massachusetts in the balance is no more a disregard of those interests than is Mr. Justice Frankfurter's neglect to perform a similar operation when inquiring into the reasonableness of the condition imposed by Louisiana.

The concurring opinion suffers from a petitio principii of which its author would surely not be guilty but for the powerful influence of the obligatio theory and its great exponent, Holmes. "Whether Louisiana may rewrite a contract, whose obligations are determined by Massachusetts ... by deleting a substantial feature of that contract and thereby enlarging the obligation of the insurance company, surely raises a serious question affecting the constitutional relationships of the States one to another." 177 To state the question in this way is to answer it. But is the obligation of the contract determined by Massachusetts, or is it determined by Louisiana to the extent that Louisiana interests are concerned and to the extent that Louisiana is in position to effectuate its interests?

${ }^{173}$ See the quotation at note 171 supra.

${ }^{174}$ See Watson v. Employers Liability Assurance Corp., 348 U.S. 66, 75-6 (1954).

175 "Of course Massachusetts also has some interest in the policy sued on in this case." Id., at 73.

${ }^{176}$ Id., at 78.

${ }^{177}$ Id., at 74. (Italics added.) "[T]o allow suits by a third-party claimant directly against the insurance company prior to a judgment against the insured is to subject the insurance company to an obligation which it had not undertaken and which indeed it had expressly refused to assume." Id., at 75. Of course Mr. Justice Frankfurter did not doubt the validity of the statute as applied to a domestic contract containing a no-action clause. 
Finally, the influence of the vested-rights theory on the concurring opinion is evident in the attempt to resurrect the Brandeis fallacy in spite of the fatal effect of Griffin v. McCoach. ${ }^{178}$ All these matters are significant because the majority of the Court rejected them. No longer is it possible to assume that the law of the state of contracting fixes the obligation of the contract, irrespective of the interests of other states; no longer is it possible to explain that apparent exceptions to the rule, predicated on local public policy, consist merely in refusing aid in the enforcement of distasteful agreements, leaving the claimant to pursue his remedies elsewhere. Louisiana's interests here clearly overrode a $d e-$ fense based on the law of another state, and sustained a judgment on the merits against the insurance company.

In closing this portion of the discussion we may refer briefly to the cases dealing with the public-law aspects of insurance regulation. ${ }^{179}$ These cases are not to be dismissed as irrelevant because they do not involve the same vestedrights concept that has been developed in the private-law cases. ${ }^{180}$ Like cases involving jurisdiction to tax, they are significant for their development of the concept of governmental interest. The interests involved, however, are different from those involved in the private-law cases. It is only for that reason, and in the interests of economy, that they are not treated in detail here.

The two outstanding cases in the series are Hoopeston Canning Co. v. Cullen ${ }^{181}$ and Allgeyer v. Louisiana. ${ }^{182}$ Of the Hoopeston case it is sufficient to say that it amply and explicitly confirms the analysis in terms of state interests. The conceptualism of Allgeyer is a thing of the past-if, indeed, it ever was so formidable as many of us have been inclined to assume. If we infer from the case that Louisiana, in the same circumstances, could not constitutionally regulate the relations between the parties arising from the agreement, it is indeed a precedent at war with the interest analysis, and we can say only that it has been deprived of vitality by subsequent decisions. Such a reading of the case, however, is unwarranted. The interests which would be involved if Louisiana were attempting to regulate the relations between the parties are quite different from those which were involved in Allgeyer; and, on reflection, the holding of that case (though not its language) can be substantially supported on the ground that, if

${ }^{178}$ See id., at 76. Mr. Justice Frankfurter concurred in the result in Griffin v. McCoach, 313 U.S. 498 (1941).

179 These are sometimes referred to as "regulatory," Watson v. Employers Liability Assurance Corp., 348 U.S. 66, 78 (1954) (concurring opinion), or "police power" cases, Overton, op. cit. supra note 11, at 120. But all the cases involve exercise of the police power to regulate insurance. The distinction lies in the fact that in the cases heretofore discussed the legislation affects the relations between the parties to the contract, whereas in the cases now to be discussed it affects only the relation between the company or its operative (or sometimes the insured) and the state.

${ }^{180}$ Cf., Frankfurter, J., concurring in Watson v. Employers Liability Assurance Corp., 348 U.S. 66, 78 (1954).

181318 U.S. 313 (1943).

${ }^{282} 165$ U.S. 578 (1897). 
allowance is made for certain principles which were taken for granted at the time, Louisiana had no legitimate interest in asserting its policy. The interest primarily involved was a revenue interest; Louisiana was attempting to require foreign insurance companies to pay a license fee if they underwrote risks within the state, even though they refrained from "doing business" within the state. ${ }^{183}$ The proceeding was one to recover a statutory penalty from a resident who, in violation of the statute, acted within the state to effect insurance on property in the state by a foreign corporation not licensed to do business there. An explicit holding that Louisiana had no legitimate interest in collecting a license tax in such circumstances, and particularly that it was not justified in implementing its fiscal policy by exacting penalties of residents who merely dealt with the company, would have been understandable. ${ }^{184}$

\section{FraternaI Insurance}

It is a notorious fact that in cases involving fraternal insurance the Supreme Court has consistently invoked the Full Faith and Credit Clause to upset the choice of law made by state courts, paying little heed to the interests of states other than that of the corporate domicile in its determination to enable such enterprises to operate under a uniform law. Some of the precedents do not have the strength with which they have been credited, and the latest in the series indicates a wholesome trend by some members of the Court away from the earlier position. When all is said, however, the fact remains that in these cases the Court has adopted a position quite inconsistent with an analysis in terms of state interests. In so doing, the Court has clearly assumed to perform a function which belongs to Congress.

Perhaps the most striking of the cases is Sovereign Camp of the Woodmen of the World v. Bolin.185 The insured, a resident of Missouri, joined a local lodge of the Nebraska society at a time when the by-laws provided that his obligation to pay dues and assessments should cease after twenty years. After this period had

${ }^{183}$ See id., at 583. See State v. Williams, 46 La. Ann. 922 (1894), for the background.

${ }^{184}$ The Louisiana law might also have been interpreted as expressing a policy of providing a local forum for local residents insured by foreign corporations, in which case it would today be conceded that the state has a legitimate interest. McGee v. International Life Ins. Co., 355 U.S. 220 (1957). But according to standards prevailing at the time, this attempt was overambitious. See St. Clair v. Cox, 106 U.S. 350 (1882); Henderson, The Position of Foreign Corporations in American Constitutional Law 77-100 (1918). The requirement that foreign insurance companies have agents in the state on whom process could be served in fact received some attention in the Allgeyer litigation. Another provision of Louisiana law which might have provided the basis for a legitimate interest was not mentioned at all, either by the state court or the Supreme Court: a statute required foreign insurance companies to deposit a sum of money with the state treasurer as security for local policyholders. Act 76, 1866, p. 115; La. Rev. L. (1896) 463. While either of these provisions might have provided a better basis for the assertion of an interest on the part of Louisiana than the requirement of a license fee, neither figured much in the discussion; and, if they had, the Court might still have doubted whether Louisiana could legitimately implement its policy by penalizing the resident who dealt with the company.

185305 U.S. 66 (1938). 
elapsed he ceased to make payments, and thereafter died. In the action on the certificate in Missouri, the society relied upon a decision of the Supreme Court of Nebraska, Trapp v. Sovereign Camp, ${ }^{186}$ holding that the by-law making the certificate fully paid in twenty years was ultra vires. The Missouri court gave judgment for the beneficiaries, holding that the contract, being made in Missouri, was governed by Missouri law and that the by-law was not ultra vires-or that, if it was, the society was estopped to plead that defense. The Supreme Court, without dissent, reversed in an opinion by Mr. Justice Roberts, holding that the judgment below "denied full faith and credit to the public acts, records, and judicial proceedings of the State of Nebraska."187 In support of its decision the Court first offered what appears to be a characterization and choice-of-law rule of its own making, independent of the Constitution:

The beneficiary certificate was not a mere contract to be construed and enforced according to the laws of the State where it was delivered. Entry into membership of an incorporated beneficiary society is more than a contract; it is entering into a complex and abiding relation and the rights of membership are governed by the law of the State of incorporation. ${ }^{188}$

It will be convenient for the time being to defer discussion of the second ground for the decision. As its third ground, the Court held that the judgment of the Nebraska court in the Trapp case was conclusive as to both the issue of ultra vires and the issue of estoppel:

[I]t need only be said that the Trapp case was a class suit in which it was determined that the petitioner lacked power, under the law of Nebraska, to issue such certificates. In such a suit the association represents all its members and stands in judgment for them, and even though the suit had a different object than the instant one it is conclusive upon all members of the association with respect to all rights, questions, or facts therein determined. 189

As its fourth ground, the Court said: "Under our uniform holdings the court below failed to give full faith and credit to the petitioner's charter embodied in the statutes of Nebraska as interpreted by its highest court." ${ }^{190}$ In brief, if we disregard the Court's apparent venture into the common law of conflict of laws and its second ground of decision, the holding was (1) that Missouri denied full faith and credit to the judgment in the Trapp case; and (2) that Missouri denied full faith and credit to the charter, a public act of Nebraska, as construed. In the latter context the judgment in the Trapp case figures not as a former adjudication, binding on the plaintiff here, but only as an authoritative construction of the Nebraska statute.

186102 Neb. 562, 168 N.W. 191 (1918).

${ }^{187}$ Sovereign Camp of the Woodmen of the World v. Bolin, 305 U.S. 66, 75 (1938).

${ }^{188}$ Id., at 75. However, the Court cited two earlier cases decided on constitutional grounds. These will be discussed below.

${ }^{189}$ Id., at 78-79.

190 Id., at 79. 
The first of these holdings is quite untenable. The Trapp case was not a class action in any such sense that the judgment therein could be binding on Bolin in his action. It is true that Trapp purported to sue on behalf of himself and all others similarly situated; but otherwise the proceeding had none of the characteristics of a class action. ${ }^{191}$ The Court would have encountered considerable difficulty in holding that the interests of Bolin were adequately represented by Trapp. It did not even attempt to do so, but held instead that Bolin was represented in the former action by the association-his adversary in the pending action. In the Trapp case, as here, the association was defending a position antagonistic to the interests of holders of paid-up certificates. How the Court could have thought that the interest of the holder of such a certificate could be adequately represented by his antagonist is a puzzle surpassed only by the willingness of commentators to accept the ruling without question. ${ }^{192}$ Our further examination of the decision, together with a review of the earlier cases, may throw some light on the Court's startling treatment of this matter.

Putting aside, then, the question of full faith and credit to the judgment in the Trapp case, we come to the holding that Missouri denied full faith and credit to the charter as a public act of Nebraska. This clearly relates back to the Court's determination that the question was not one of contract but of a "complex and abiding relation," governed by the law of the corporate domicile: "Another State, wherein the certificate of membership was issued, cannot attach to membership rights against the society which are refused by the law of the domicile." 193 This is as conceptualistic and territorialist as the apparent rule of the Dodge case, referring to the law of the place where a contract is made. It permits no recognition of the possible interest of the state where the insured resides in regulating the insurance transaction. It enforces uniformity in accordance with the law of the corporate domicile irrespective of the interests of other states. We may concede that Nebraska has an interest in fostering this type of enterprise, and that from Nebraska's point of view the nation-wide application of Nebraska law would be desirable. But what of the interest of Missouri?

It is when we inquire into Missouri's policy, and its interest in the application of that policy, that the second ground for the court's decision, heretofore neglected, becomes significant. All states exempt fraternal benefit societies from their general insurance laws. ${ }^{194}$ Missouri is, and was, no exception. In 1879 it

191 The deficiencies of the proceeding as a class action are pointed out in the arguments of counsel, id., at 70-71. For a general discussion, see 3 Moore's Federal Practice c. 23 (2d ed., 1948).

${ }^{192}$ See, e.g., Carnahan, Conflict of Laws and Life Insurance Contracts 166 (2d ed., 1958); Full Faith and Credit: Preferential Treatment of Fraternal Insurers, 57 Yale L. J. 139 (1947). ${ }^{193} 305$ U.S. 66, 75 (1938).

${ }^{394}$ Yale L. J., op. cit. supra note 192; see also Basye, History and Operation of Fraternal Insurance 108-132 (1919). The latter reference is enlightening as to the political pressure exerted by fraternal organizations to obtain, if not complete freedom from regulation, "special consideration" and uniform laws. 
authorized incorporation of fraternal beneficiary societies and exempted them from the general laws regulating insurance. Two years later it exempted foreign as well as domestic societies. A revision of the private corporation laws in 1889 exempted domestic fraternal societies from the general insurance laws but, apparently through inadvertence, made no reference to foreign societies. In 1897 foreign societies were dealt with again, being exempted from the insurance laws if they registered and complied with certain other conditions. There was thus, as both the state court and the Supreme Court observed, a "hiatus" of eight years, during which the status of foreign fraternal societies was ambiguous. They continued to operate in the state, organizing lodges, obtaining members, and issuing benefit certificates. It was in this period-in 1896-that Bolin joined the lodge and obtained his certificate. ${ }^{195}$

Because there was, technically, no law on Missouri's books in 1896 exempting foreign societies from the insurance laws, the Missouri court insisted upon treating the Woodmen of the World as an old-line company, subject to those laws. It is a little difficult to understand this insistence. So far as appears, there was nothing in the laws regulating commercial insurance which would have aided the court in deciding for the plaintiff on the issue as to whether the certificate was ultra vires. ${ }^{196}$ According to the Missouri court itself, nothing hinged on this determination, since the opinion states emphatically that the finding that the contract was not ultra vires would stand even if the society were not treated as subject to the general laws. ${ }^{197}$ On rehearing this position may have been modified, though in an obscure way. The court seems to be saying that if, in other similar cases, the society can show compliance with the act of 1897 , that fact may retroactively give it status as a fraternal society during the period 18891897. Even so, however, the court would decide the questions of ultra vires and estoppel by Missouri law; and the question whether that law would make a distinction between old-line companies and fraternal orders with respect to these questions is left open. ${ }^{198}$

All this is confusing, and seems to lead nowhere in particular. For purposes of the record before it, the Missouri court emphatically adhered to the view that it made no difference whether the defendant was regarded as a fraternal society or as an old-line company subject to the general regulatory laws. Then why did it insist upon treating the defendant as a non-exempt, old-line company? The best guess, perhaps, is that it sought thus to avoid the compulsion of Supreme Court decisions holding that the law of the state of incorporation is controlling in cases involving fraternal societies. ${ }^{199}$ By characterizing the question before it

${ }^{195}$ This background is briefly recounted in the opinion of Mr. Justice Roberts, 305 U.S. 66, 76-78 (1938).

${ }^{196}$ Cf. New York Life Ins. Co. v. Dodge, 246 U.S. 357 (1918), where the Missouri statute provided against forfeiture in certain circumstances.

197 Bolin v. Sovereign Camp, 112 S.W.2d 582 (K.C., Mo. C.A., 1937).

${ }^{198}$ Id., at 593.

${ }^{199}$ See note 201 infra. 
as one concerning a commercial insurance contract rather than one concerning fraternal societies, the court apparently hoped to justify application of the law of the place of contracting instead-in order to decide whether the contract was ultra vires. At any rate, the Supreme Court appears to have placed such an interpretation on the Missouri court's decision:

The court below was not at liberty to disregard the fundamental law of the petitioner and turn a membership beneficiary certificate into an old line policy to be construed and enforced according to the law of the forum. The decision that the principle of ultra vires contracts was to be applied as if the petitioner were a Missouri old line life insurance company was erroneous in the light of the decisions of this court which have uniformly held that the rights of members of such associations are governed by the definition of the society's powers by the courts of its domicile. ${ }^{200}$

The significant fact which emerges from all this is that it nowhere appears that Missouri had formulated any policy whatever for the protection of its residents in their dealings with such societies. On the contrary, that state was no laggard in the movement to give such societies "special consideration" and exempt them from ordinary regulation designed for the protection of the insured. For a brief period, in which the certificate in suit was issued, Missouri had by oversight neglected to give exemption to foreign societies; but neither in this period nor at any time did it announce a policy hostile to such organizations, or inconsistent with the policy of Nebraska. In this light, the decision is consistent with the interest analysis.

We can find no such consolation, however, in all of the cases in this series. The first two, Royal Arcanum v. Green ${ }^{201}$ and Hartford Life Ins. Co. v. Ibs, ${ }^{202}$ were decided on the same day. In Green, the action was by a New York member against a Massachusetts society, and the question was whether the society could, by amendment of its by-laws, require the member to pay assessments at a rate higher than that stated in his certificate. The New York Court of Appeals held that it could not, and the Supreme Court reversed, holding that New York had denied full faith and credit to the laws of Massachusetts. The opinion of Chief Justice White is not a model of lucidity, but close examination of it reveals some points of interest and significance.

Here, as in Bolin, there had been a prior action, purporting to be a class action, in the domiciliary state, in which it was determined by the Massachusetts court that the society could validly increase assessments without the consent of members. This proceeding had at least as much claim to be regarded as a class action as had the Trapp case in Nebraska. If the judgment in such a proceeding is ever to be properly regarded as binding on members in other states, it would

200305 U.S. 66, 78 (1938).

${ }^{201} 237$ U.S. 531 (1915).

202237 U.S. 662 (1915). This involved a stock company; but since what was involved was a "safety fund certificate" issued on the assessment plan, the case is treated as similar to those involving fraternal societies. See Carnahan, op. cit. supra note 192, at $153 \mathrm{n} .97$. 
seem that the Court might have rested its decision in Green on the ground that New York denied full faith and credit to the judgment-especially since in the New York courts the society had invoked the Full Faith and Credit Clause specifically only in that connection. The Court did not do so. Instead, it specifically grounded its decision on the denial of full faith and credit to the laws of Massachusetts, as interpreted by the courts of that state, and did not reach the question whether the Massachusetts judgment was res judicata. This behavior indicates some uncertainty as to the binding effect of the judgment, and the opinion contains a fairly clear indication of the basis for that uncertainty-a basis only hinted at in the Bolin case. In the prior action at the corporate domicile the plaintiffs were, apparently, Massachusetts members of the society. No question of conflict of laws was suggested or decided. The plaintiffs could hardly be said to have been representative of members in other states; the issue could hardly be said to be a common one-unless, indeed, one is to assume that the applicability of Massachusetts law was so clear and inevitable that the opportunity to litigate the question was of no value. Chief Justice White seems to have made just such an assumption. At two places in the opinion ${ }^{203}$ he seems to be saying: (1) If Massachusetts law is applicable, the prior judgment is res judicata because the effect of that law was litigated and determined; (2) However, if New York law is applicable to certificates issued in that state to local residents, the Massachusetts judgment is not binding with respect to New York members; (3) Since Massachusetts law governs, the former judgment is conclusive, although it is unnecessary to decide that question because full faith and credit is required to the Massachusetts law as such. By such strange reasoning did the Court, regrettably, avoid facing up to the interesting question: Is the judgment in a class action brought against the society at its domicile by local members binding on members in other states when the possible applicability of the laws of their respective home states is neither suggested nor determined?

Chief Justice White's opinion is quite possibly the source of the remarkable holding in Bolin that the judgment in the prior action is binding because affected members were represented therein by their adversary, the society. At three points the opinion refers to such representation, ${ }^{204}$ specifically relying on the stockholders' liability cases, in which it was held that with respect to the questions of insolvency and the amount due to creditors the stockholders are represented by the company. That those cases are not in point is too clear for discussion.

Chief Justice White's argument in support of the position that the law of the domicile is applicable, and that other states are required by the Full Faith and Credit Clause to apply it, reduces to two propositions: (1) Such organizations as these could not conveniently operate if the validity of assessments were to be

203237 U.S. 531, 541, 545 (1915).

201 Id., at 543-44, 545, 546. 
determined by a diversity of state laws; (2) therefore, and in the nature of things, the law of the domicile governs:

Before coming to consider the subject in its first aspect as controlled by authority, we briefly contemplate it from the light of principle....

It is not disputable ... that all the rights of the complainant concerning the assessment ... had their source in the constitution and by-laws and therefore their validity could be alone ascertained by a consideration of the constitution and by-laws.... [1] $t$ necessarily follows that resort to the constitution and by-laws was essential unless it can be said that the rights in controversy were to be fixed by disregarding the source from which they arose and by putting out of view the only considerations by which their scope could be ascertained. Moreover, ... [the laws of Massachusetts] were integrally and necessarily the criterion to be resorted to for the purpose of ascertaining the significance of the constitution and by-laws. Indeed, the accuracy of this conclusion is irresistably manifested by considering the intrinsic relation between each and all the members concerning their duty to pay assessments and the resulting indivisible unity between them in the fund from which their rights were to be enjoyed. The contradiction in terms is apparent which would rise from holding on the one hand that there was a collective and unified standard of duty and obligation on the part of the members themselves and the corporation, and saying on the other hand that the duty of members was to be tested isolatedly and individually by resorting not to one source of authority applicable to all but by applying many divergent, variable and conflicting criteria. In fact their destructive effect has long since been recognized. ${ }^{205}$

The interest of New York in securing to its residents the benefits bargained for, at the rates agreed upon, was ignored.

The Ibs case, which arose in Minnesota and involved the validity of assessments made by a Connecticut company in order to maintain a margin in the fund from which benefits were paid, was decided solely on the basis of full faith and credit to the judgment in a prior class action at the corporate domicile. For present purposes, therefore, our interest in the case is limited to the question, raised by the Bolin and Green cases, as to the binding effect of such a judgment upon members resident in other states. ${ }^{206} \mathrm{We}$ shall not find an answer to that question, but we shall find further support for the view that the ruling of Bolin as to this point was unsound. At the outset it is clear that Mr. Justice Lamar understood the theory and function of class actions, and rested his decision on the ground that Ibs was represented by the thirty certificate holders who were complainants in the action at the domicile; there was no nonsense about his being represented by the corporate adversary. Moreover, it is expressly stated that among the complainants in the prior action were members residing in different states. ${ }^{207}$ This fact is not conclusive, but it suggests that the

${ }^{205}$ Id., at $541-42$ (italics added); cf. New York Life Ins. Co. v. Cravens, 178 U.S. 389 (1900).

${ }^{208}$ In passing it may be noted that here, as in cases where the decision is rested on the requirement of full faith and credit to the laws of the state of incorporation, the Court stressed the need for the affairs of such organizations to be governed by a uniform law. 237 U.S. 662, 670-71 (1915).

${ }^{207}$ Id., at 667. 
interests of nonresident members were represented as they were not in the other two cases, and that if the representatives did not urge the applicability of the laws of other states other nonresident members might be precluded by their failure to do so. Finally, the issue as we have stated it in connection with Bolin was not presented. The Minnesota court, in two opinions, did not discuss choice of law and did not hold that Minnesota law, rather than the law of the corporate domicile, governed; it discussed the validity of the assessments as a matter of general law, citing cases from Minnesota and other states. ${ }^{208}$ There is no indication that the law of Connecticut was pleaded or otherwise invoked. Hence we still have no answer to the question whether a member is precluded from insisting on the law of the state of his residence by a former judgment in a class action in which the relevance of that law was not considered. All we can say is that nothing but confusion resulted from the citation of this clear-headed decision in the Green ${ }^{209}$ and Bolin ${ }^{210}$ cases for the proposition that the affected member is represented by the society.

Bartford Life Ins. Co. v. Barber ${ }^{211}$ is in every respect similar to Ibs. The Court reversed a judgment of the Missouri Supreme Court denying full faith and credit to the judgment in the same class action involved in that case. ${ }^{212}$

Modern Woodmen of America v. Mixer ${ }^{213}$ has two aspects. The certificate was issued in 1901 in South Dakota, where the member resided at the time. In 1910 the member left his home, then in Nebraska, and except for a letter in the following year was not heard from thereafter. ${ }^{214}$ After the lapse of more than seven years the beneficiary brought suit on the policy in Nebraska, relying on the presumption of death after seven years' unexplained absence. The society pleaded a by-law, adopted in 1908, according to which unexplained absence was excluded as a ground for recovery until the insured's full life expectancy had expired. Also pleaded was the decision of the Supreme Court of Illinois (Illinois being the corporate domicile) in Steen v. Modern Woodmen of America, ${ }^{215}$ holding the by-law valid as applied to certificates issued before its adoption.The Nebraska Supreme Court affirmed a judgment for the plaintiff on the ground that, while the member had agreed to be bound by by-laws adopted in the future, the by-law in question unreasonably altered rights arising from the cer-

${ }_{208}$ Ibs v. Hartford Life Insurance Co., 119 Minn. 113, 137 N.W. 289 (1912); 121 Minn. 310, 141 N.W. 289 (1913).

${ }^{209} 237$ U.S. 531, 546 (1915).

210305 U.S. 66,79 n.14 (1938).

211245 U.S. 146 (1917).

${ }^{212}$ It is difficult to see what purpose was served by the citation of this decision in Bolin. See 305 U.S. 66, 78 n.12 (1938).

213267 U.S. 544 (1925).

${ }^{214}$ Transcript of Record at 41 et seq. Both parties took the position that in the absence of proof of the law of South Dakota it should be presumed to be the same as that of Nebraska. Brief for Petitioner at 2; Brief for Appellee [Respondent] at 3,

215296 IIl. 104, 129 N.E, 546 (1921). 
tificate and was invalid. ${ }^{216}$ The Supreme Court unanimously reversed, Mr. Justice Holmes writing a brief opinion:

The indivisible unity between the members of a corporation of this kind in respect of the fund from which their rights are to be enforced and the consequence that their rights must be determined by a single law, is elaborated in Supreme Council of the Royal Arcanum v. Green.... The act of becoming a member is something more than a contract, it is entering into a complex and abiding relation, and as marriage looks to the domicil, membership looks to and must be governed by the law of the State granting the incorporation. ... It does not matter that the member joined in another State. ${ }^{217}$

The Court squarely held that full faith and credit had been denied to the Illinois charter as construed by the Illinois court. It did not suggest that credit had been denied to the judgment in the Steen case. It could not very well have relied on that judgment, because Mrs. Steen purported to sue for herself alone; there was no pretense of a class action. Only by regarding the society as Mrs. Mixer's representative in the Steen case could the Court have held the judgment conclusive. It is heartening that Mr. Justice Holmes did not assume that indefensible position.

Analyzing the case in terms of state interests, we concede the interest of Illinois in fostering such societies and inquire what governmental policy was expressed by Nebraska (or South Dakota) in its rule that death is presumed after seven years' absence. The answer is, at least for purposes of the question before us: None. As the Tllinois Supreme Court said in the Steen case:

This is an arbitrary presumption. ... It was a rule born of necessity... [T]here is now no sound reason for continuing the rule except that it has existed for so long a time that convenience makes it the best rule to follow where no other rule is established by statute or agreement... . [P]arties may by contract change an established rule of evidence and provide that a different rule shall apply in determining controversies that may arise between the parties to the contract. ${ }^{218}$

There is no indication that Nebraska's conception of the presumption was different. No statute and no policy of Nebraska invalidated agreements whereby the presumption was waived. ${ }^{219}$ If nothing more were involved than a stipulation in the certificate abrogating the presumption, it would be quite clear that Nebraska had no contrary policy, and that full faith and credit to the law of Illinois was required.

But the Mixer case involved the validity of a by-law enacted after the certificate had been issued. In this aspect the case is similar to Royal Arcanum v.

${ }^{216}$ Mixer v. Modern Woodmen of America, 111 Neb. 334, 197 N.W. 129 (1923). See Garrison v. Woodmen of America, 105 Neb. 25, 178 N.W. 842 (1920); cf. Modern Woodmen of America v. Mixer, 267 U.S. 544, 550 (1925).

${ }^{217}$ Id., at 551.

218296 Ill. 104, 112-14, 129 N.E. 546, 550 (1921).

${ }^{219} \mathrm{Cf}$. statutes invalidating agreements to shorten the period of limitations. See Order of United Commercial Travelers v. Wolfe, 331 U.S. 586 (1947). 
Green: ${ }^{220}$ the state of the insured's residence has an interest in protecting him against unilateral action by the managers of the society which, in its view, unreasonably derogates from the rights arising under the certificate, even though the member has agreed to be bound by future by-laws. One may disagree with Nebraska (and a number of other states ${ }^{221}$ ) in the position that the by-law in question unreasonably altered rights created by the certificate; indeed, the opinion of the Illinois court in the Steen case is very persuasive. Surely, however, this is a matter which Nebraska can decide for itself, at least so far as its domestic policy is concerned; and the fact that this was not a domestic case merely means that Nebraska's policy for the protection of its residents was in conflict with the policy of Illinois, which would allow greater latitude to fraternal societies in the modification of promised benefits. The fact that enforcement of Nebraska's policy may make it impracticable or inconvenient for such societies to operate on a nationwide basis is not, as Mr. Justice Holmes appears to have assumed, a reason why Nebraska's policy should be required to yield to that of Illinois. The determination that such societies are to be fostered at the expense of interests of other states is not one to be made unilaterally by Illinois, nor is it one that can appropriately be made by the Supreme Court. It is a political determination which can appropriately be made only by Congress in the exercise of its powers under the Full Faith and Credit Clause.

The last case in the series is Order of United Commercial Travelers v. Wolfe. ${ }^{222}$ The member and his beneficiary were at all relevant times residents of South Dakota; the defendant was an Ohio corporation. The member's death occurred when his physician administered a local anaesthetic in the course of an examination, it appearing that he suffered from a "rare idiosyncrasy." The beneficiary filed suit on the policy in a South Dakota court, claiming recovery for accidental death. On grounds of diversity of citizenship the action was removed to the federal court, which found for the plaintiff. The judgment was reversed on the merits by the court of appeals, which held that death was not accidental within the terms of the policy.223 The judgment of the court of appeals was made the judgment of the district court, and the matter seemed to be at an end. However, for some unexplained reason, the parties thereafter entered into a stipulation pursuant to which the case was dismissed without prejudice. ${ }^{224}$ The beneficiary assigned her rights to a citizen of Ohio, obviously to prevent removal, and the assignee filed suit in a South Dakota court some three years after the society had disallowed the claim. The society pleaded a provision of its constitution to

${ }^{200}$ Note 201 supra.

221 See the cases cited in Steen v. Modern Woodmen of America, 296 Ill. 104, 119, 129 N.E. 546, 552-53 (1921).

22331 U.S. 586 (1947).

223 Order of United Commercial Travelers v. Shane, 64 F.2d 55 (C.A.8th, 1933).

224 Order of United Commercial Travelers v. Wolfe, 331 U.S. 586, 598 (1947). 
the effect that no action should be brought after six months from the disallowance of the claim. ${ }^{25}$ Relying on a South Dakota statute providing that "[e]very provision in a contract restricting a party from enforcing his rights under it by usual legal proceedings in ordinary tribunals or limiting his time to do so, is void," the state court affirmed a judgment for the plaintiff. ${ }^{226}$ The Supreme Court reversed, holding that South Dakota had denied full faith and credit to the public acts of Ohio under which the society was incorporated.

For the first time in this series of cases the Court was sharply divided, Mr. Justice Black writing a dissenting opinion in which three other members of the Court joined. ${ }^{26 a}$ The majority opinion, written by Mr. Justice Burton, follows lines which are by now familiar. Some of its more significant aspects may be summarized as follows: (1) The need for uniformity in the obligations of the society to its members is emphasized from the beginning; ${ }^{227}$ (2) Reliance is placed solely on "the character of the membership obligation" although there was color for the contention that the contract was "made in Ohio";228 (3) The Ohio citizenship of the nominal plaintiff is disregarded, and the beneficiary is conceded whatever comfort is to be found in the fact that she and the insured were residents of South Dakota;229 (4) The ordinary rule that the forum may apply its own statute of limitations is held inapplicable, the distinguishing factor being membership in an organization which (it is emphasized) is not operated for profit and has a representative form of government; ${ }^{230}$ and (5) The existence of a South Dakota policy disapproving contractual shortening of the period of limitations is doubted. ${ }^{23 \mathrm{~L}}$

Three aspects of the opinion require special attention.

(1) Challenged by cases in which the Court had given explicit consideration to the interest of a state in having its law applied, Mr. Justice Burton acknowledged the relevance of "evaluated public policy" and said: "The weight of public policy behind the general statute of South Dakota, which seeks to avoid certain provisions in ordinary contracts, does not equal that which makes necessary the recognition of the same terms of membership for members of fraternal benefit societies wherever their beneficiaries may be."232 Thus the Court, accepting the interest analysis, proceeds unabashedly to evaluate the relative merits of the

${ }^{225}$ Such a provision had been held valid in Bartley v. National Business Men's Ass'n, 109 Ohio St. 585, 143 N.E. 386 (1924).

${ }^{226}$ Wolfe v. Order of United Commercial Travelers, 70 S.D. 452, 455, 18 N.W.2d 755, 756 (1945).

${ }^{226 a}$ Order of United Commercial Travelers v. Wolfe, 331 U.S. 586, 625 (1947).

227 Id., at 592.

${ }_{228} \mathrm{Id}$., at 600-601.

229 Id., at 601 .

${ }^{230} \mathrm{Id}$., at 604-11.

${ }^{231}$ Id., at 612 and n.23. Cf. id., at 594. Space does not permit a full discussion of this point, but the Court's position with respect to it is quite unconvincing.

232 Id., at 624. 
competing state interests and to declare that the interest of South Dakota is inferior. ${ }^{233}$

(2) If Mr. Justice Frankfurter is right in his concurring opinion in the Watson case, ${ }^{234}$ the fact that this society was licensed to do business in South Dakota should have furnished a basis for upholding the application of South Dakota law. The Court did not recognize such a basis. On the contrary, it turned the circumstance of licensure into an argument against the application of South Dakota law: since the state allowed the society to do business within its borders, having constructive notice of its constitutional provision limiting the time within which action could be brought, and did not revoke or refuse to renew the license, the assertion of an interest in the application of its law and policy is discredited. ${ }^{235}$ Comment on this anomaly would seem to be superfluous.

(3) The Brandeis fallacy ${ }^{236}$ is revived in a slightly different, and insidious, form of statement: ${ }^{237}$

There would be little sound public policy in permitting the courts of South Dakota to recognize an action to collect the full benefits to be derived from a membership in the petitioner society, while, at the same time, nullifying other integral terms of that same membership which limit certain rights of beneficiaries to enforce collection of such benefits. It is of the essence of the full faith and credit clause that, if a state gives some faith and credit to the public acts of another state by permitting its own citizens to become members of, and benefit from, fraternal benefit societies organized by such other state, then it must give full faith and credit to those public acts and must recognize the burdens and limitations which are inherent in such memberships. ${ }^{238}$

It is easy to understand how anyone, schooled in the assumption that the law of one and only one state must govern the whole of any transaction, might slip into such circular reasoning. ${ }^{239} \mathrm{On}$ the other hand, if the Court understands the interest analysis which it employed in Alaska Packers ${ }^{240}$ and Griffin v. McCoach ${ }^{241}$ and which Mr. Justice Burton acknowledges in his opinion, it ought also to understand that a transaction may be governed, in some or all of its aspects, by the laws of two or more states, as their interests may appear. Here the laws of South Dakota and Ohio concurred in fostering fraternal societies and in providing

${ }^{233}$ Indeed, the Court goes further and informs South Dakota that it has mistaken its own interests: "It is concerned as much with the validity and fairness of the obligations to be enforced by assessments against its citizens who become members of the society as it is with the benefits to be claimed by those who become its beneficiaries." Id., at 625 .

234 Note 168 supra.

${ }^{235}$ Order of United Commercial Travelers v. Wolfe, 331 U.S. 586, 594, 624 (1947). Cf. the dissenting opinion, id., at 632 .

${ }^{236}$ Note 85 supra.

${ }^{237} \mathrm{It}$ is revived in substantially its original form at 331 U.S. 586, 610 (1947).

${ }^{238}$ Id., at 624-25. (Italics in the original.)

${ }^{239}$ Cf. California Law Revision Commission, Recommendation and Study Relating to Choice of Law Governing Survival of Actions 16, 17 (1957), discussed in Currie, Survival of Actions: Adjudication versus Automation in the Conflict of Laws, 10 Stan. L. Rev. 205, 235 (1958).

${ }^{240}$ Note 42 supra. 24' Note 161 supra. 
sanctions to enforce their obligations under certificates of insurance. They differed with respect to the validity of that portion of the agreement which limited the time within which action might be brought. South Dakota had an interest in the application of its policy just as Ohio had an interest in the application of its contrary policy. It is misleading to suggest that South Dakota adopted part of the Ohio law and rejected part. Its own law was quite sufficient to give rise to the obligation and also to invalidate the time limitation where its residents were concerned. ${ }^{242}$

As an exposition of the interest analysis the dissenting opinion of Mr. Justice Black leaves much to be desired. (1) It relies on the maxim of conflict of laws to the effect that a state will apply its own statute of limitations, and on the cases holding that the Full Faith and Credit Clause does not require the contrary, without adequate analysis of the different situations in which the question may be presented;243 (2) It overstates the case by ridiculing the treatment of the society's constitution as part of the "law" of Ohio, implying that Ohio has no legitimate interest in the transaction, and suggesting that if the action were brought in Ohio that state should be required to defer to the interest of South Dakota;24 (3) It relies uncritically, and in a way not very consistent with $\mathrm{Mr}$. Justice Black's majority opinion in Watson, ${ }^{245}$ on the power of South Dakota to impose conditions on the privilege of the foreign corporation to do business in the state; ${ }^{246}$ (4) It relies on the fact that the contract was made and to be performed in South Dakota, even citing Delta \& Pine Land Co. in support of the position; ${ }^{247}$ (5) It distinguishes the Bolin case on the ground that all that was there involved was full faith and credit to the judgment in the prior "class" action; $;^{248}$ and (6) It assumes that the function of the Court in such a case is to

242 In the case of a contract between two natural persons, one resident in Ohio and one in South Dakota, it is not likely that the Court would make the argument advanced by Mr. Justice Burton; it is too clear by now that the interest of the state of residence of one of the parties can override the law of the place where the contract is "made." But all the Court's emphasis on the charter of the society as the necessary source of any rights under the contract does not change the fact that the problem is precisely the same as if a natural person rather than a corporation were involved.

${ }^{243}$ Order of United Commercial Travelers v. Wolfe, 331 U.S. 586, 627-30 (1947). In a footnote Mr. Justice Black does acknowledge the authority of Home Ins. Co. v. Dick, 281 U.S. 397 (1930), and notes that the basis for the decision was the lack of an interest on the part of Texas; but this is clouded by the concept of "minor interest." Id., at 628 n.2.

${ }^{244}$ Id., at 628 n.2, 629-30 et seq.

${ }^{245}$ Watson v. Employers Liability Assurance Corp., 348 U.S. 66 (1954).

${ }^{246}$ Order of United Commercial Travelers v. Wolfe, 331 U.S. 586, 630 et seq. (1947).

247 Id., at 632 et seq. Hartford Accident \& Indemnity Co. v. Delta \& Pine Land Co., 292 U.S. 143 (1934). One cannot be consoled by the effort to soften the harsh territorialist outlines of this position by reference to "the number and importance of the incidents involved... which occurred in South Dakota." 331 U.S. 586, 632. The cumulation of "contacts" or incidents is not the same as an analysis of the interest of the state.

${ }^{248}$ Id., at 638. Sovereign Camp of the Woodmen of the World v. Bolin, 305 U.S. 66 (1938). The grounds on which Mixer is distinguished are hardly more satisfactory. 331 U.S. 586, 638-39. 
"weigh all the interests of each state involved." ${ }^{249}$ In fact Mr. Justice Black does not undertake to choose between competing interests of South Dakota and Ohio, arguing instead that Ohio has no governmental interest; but the assumption that it is the function of the Court to weigh and choose in cases of true conflict is not likely to win support for the analysis in terms of state interests.

The most effective portion of Mr. Justice Black's opinion is that in which he attacks the majority's assumption that a uniform law for fraternal orders is a constitutional necessity and that members of a society who control its affairs through a representative form of government do not need the protection of the laws of their home states. Contemporary comment on the Wolfe decision tended to take much the same line. ${ }^{250}$ Such argument is effective in so far as its purpose is to show that the state of the residence of the insured has a substantial interest which cannot be overridden except by a political decision of the Court. Its effectiveness is greatly impaired when it is advanced in a context which suggests that the judges who advance it would merely reach a contrary political decision. The character of information concerning the economic history and the business practices of this form of insurance organization is such that it ought to be apparent that the Court should be concerned with it only for the purpose of determining whether a state has a legitimate interest, and not for the purpose of determuning which state policy is the more desirable as a national matter.

In closing this phase of the discussion we may notice briefly a decision which does not relate to fraternal societies but which, as Mr. Justice Black indicates, ${ }^{251}$ is closely related. In National Mutual B. \& L. Ass'n v. Brahan ${ }^{252}$ a Mississippi resident sued a New York building and loan association for the return of interest payments which were usurious according to the law of Mississippi. The contract purported to be made in New York, and the company invoked both the Due Process Clause and the Full Faith and Credit Clause. Without giving weight to the fact that this association, like a fraternal benefit society, dealt only with its own members, and without suggesting a need for uniformity in the regulation of its affairs, the Court sustained Mississippi's application of its own law. It did so on the ground of that state's power to attach conditions to the foreign corporation's privilege of carrying on a local business; but, as we have seen, such conditions would be invalid in the absence of a legitimate interest on the part of the state. The decision thus supports the interest analysis, and specifically tells against the special treatment accorded to fraternal benefit societies..$^{253}$

$$
\begin{aligned}
& { }^{249} \text { Id., at } 634 . \quad{ }^{250} \text { See, e.g., Yale L. J., op. cit. supra note } 192 . \\
& { }^{253} \text { Order of United Commercial Travelers v. Wolfe, } 331 \text { U.S. 586, } 636 \text { (1947). } \\
& { }^{252} 193 \text { U.S. } 635 \text { (1904). }
\end{aligned}
$$

${ }^{253} \mathrm{~A}$ serious question, however, may be raised concerning the interest of Mississippi. Its usury laws exempted domestic building and loan associations dealing with their own members. That being so, can the state be said to have had a policy for the protection of its residents dealing with such associations? Conceivably, it might have had such a policy, subject to an exception only in the case of associations which, because organized under local law, afforded 


\section{TORTS}

Mr. Justice Stone, in his historic employment of the interest analysis in Alaska Packers, was seemingly resigned to the Court's commitment to a mechanical, territorialist approach in tort cases; he did not attack that supposed commitment, but distinguished liability under workmen's compensation acts from tort liability. ${ }^{254}$ The situation is not so discouraging now. Carroll v. Lanza ${ }^{255}$ and Watson v. Employers Liability Assurance Corp. ${ }^{256}$ which we have discussed, respectively, under the heads of workmen's compensation and commercial insurance, may with equal justification be regarded as tort cases. They impressively demonstrate that in this field the Court is not dominated by territorialist dogma but is concerned with the policies and interests of the states involved. For the sake of completeness, however, the two cases which led Mr. Justice Stone to his conclusion should be considered.

As it happens, both cases present a feature new to our discussion: instead of two coordinate states, each case involved a state on the one hand and federal territory on the other. Because of this feature, the discussion must proceed on two levels. In so far as possible, we shall consider the cases as if they involved an ordinary "conflict of laws" problem between states, and then consider briefly whether the involvement of federal legislative jurisdiction is significant.

In Western Union Tel. Co. v. Chiles ${ }^{257}$ a message was sent from Richmond, Virginia, addressed to a gunner on board a naval vessel at the Norfolk Navy Yard, a federal enclave in Virginia. The message was apparently delivered to the man on duty at the vessel's gangway; it never reached the addressee, who sued in the Virginia courts to recover a "penalty" of one hundred dollars imposed by a Virginia statute for failure to deliver. The Court, reversing a judgment for the plaintiff, rested its decision on the provision of the Constitution investing Congress with exclusive legislative power over federal enclaves within a state. ${ }^{258}$ The gist of the opinion is that only Congress has power to impose penalties for conduct, or neglect, occurring solely within such federal territory.

It should be observed, first of all, that no conflict between the Virginia law and the law in force at the Navy Yard was made to appear: the latter law was not pleaded, and, if it was judicially noticed, its tenor was not stated. Viewing the case in terms of due process and full faith and credit, it seems clear that the

safeguards which, in the judgment of the legislature, made the protection of the usury laws unnecessary. If, however, the foreign association, by virtue of its organization and its compliance with Mississippi statutes regulating activities by foreign corporations, were found to possess the same qualities as domestic associations in this respect, the arbitrariness of the discrimination would throw considerable doubt on the reasonableness of the condition imposed and on the existence of any real protective policy.

${ }^{254}$ Alaska Packers Association v. Industrial Accident Commission, 294 U.S. 532, 541 (1935).

255349 U.S. 408 (1955). 256348 U.S. 66 (1954).

257214 U.S. 274 (1909), rev'g 107 Va. 60, 57 S.E. 587 (1907).

258 U.S. Const. Art. 1, \$8, clause 17. 
application by Virginia of its own law should not be stricken down in the absence of a showing that such application is in derogation of rights arising under the law of another jurisdiction. ${ }^{259}$ The defendant having failed to bring to the attention of the Virginia court any information as to the tenor of the foreign law, that court was confronted with the question whether application of its own law was appropriate in the circumstances. Apart from considerations relating to the supremacy of federal law, that would not seem to be a constitutional question, al though the federal courts have had strong opinions concerning the question as a matter of common law. ${ }^{260}$ In such circumstances, the court which is trying the case is justified in applying the rule of decision supplied by its own law as a matter of course, at least where that law, properly construed, does not appear to be appropriate solely for local application. ${ }^{261}$ If we inquire how the Virginia statute should be construed with respect to cases involving foreign elements, we find, significantly, that Virginia probably had no interest in the application of its law in the circumstances of the Chiles case. If the "penalty" is regarded as designed to influence conduct within the state, it has no application to conduct elsewhere; if it is regarded as compensation, in the form of liquidated damages, to the injured person, it has no application where that person is not within the reach of the state's governmental concern, and there is no indication that the addressee was a domiciliary or a resident, or that he otherwise had any relevant connection with the state. ${ }^{22}$ On this basis, the principles of due process and full faith and credit which we have been considering should preclude the application of Virginia law-provided the contrary foreign law is appropriately brought to the attention of the court. But in the absence of a showing of the tenor of the foreign law, and apart from considerations relating to the supremacy of federal law, no constitutional problem is presented.

The relevance of the tenor of the foreign law was obscured by the Court's disposition of the case in terms of the exclusive jurisdiction of Congress over the Navy Yard. But the essential character of the question is not changed by thus shifting the framework of the discussion. The basic question is whether Virginia, without the justification of a legitimate governmental interest, was intermed-

${ }^{259}$ Chicago \& Alton R.R. v. Wiggins Ferry Co., 119 U.S. 615 (1877); Order of United Commercial Travelers v. Wolfe, 331 U.S. 586, 629 n. 3 (1947)(dissenting opinion); see Currie, On the Displacement of the Law of the Forum, 58 Col. L. Rev. 964, 1025-26 (1958).

${ }^{260}$ See Cuba R.R. v. Crosby, 222 U.S. 473 (1912); Walton v. Arabian American Oil Co., 233 F.2d 541 (C.A.2d, 1956), cert. denied 352 U.S. 872 (1956).

${ }^{261}$ See Currie, op. cit. supra note 259, at 1017.

262 Under the statute the penalty was payable either to the sender or to the addressee. The Court's statement that "[ $t$ ]he case does not call for the consideration of the effect of a contract made within the State of Virginia for the seasonable transmission and delivery of a telegram," 214 U.S. 274, 277-78, suggests that if the action had been brought by the sender a different characterization of the problem might have produced a different result. And, if the sender were a resident of Virginia, the state would have an interest in applying its policv for his protection. See the discussion of Western Union Tel. Co. v. Commercial Milling Co., 218 U.S. 406 (1910), at note 264 infra. 
dling so as to disturb legal relations which were the sole concern of another sovereign. That problem, as it is presented in the due process and full faith and credit cases, is not avoided by concentrating on the "exclusive legislative power" of Congress in the federal enclave any more than the problem involved in the jurisdiction of the Virgin Islands to grant divorces to nonresidents was avoided by concentrating on the provision of the organic act which limited the power of the territorial legislature to "subjects of local application."263

These remarks may be clarified by a parenthetical consideration of the case cited by Mr. Justice Stone for comparison with the two which led him to his conclusion regarding the Constitution and the choice of law in tort cases. This was Western Union Tel. Co. v. Commercial Milling Co. ${ }^{264}$ decided four years after the Chiles case, in which the sender of a message from Michigan to Missouri sued for damages for nondelivery. The message got as far as Chicago and no farther. The company pleaded a provision of the contract limiting its liability, and the plaintiff relied on a Michigan statute invalidating agreements to limit liability for negligence. The Michigan court gave judgment for the plaintiff, and the Supreme Court affirmed. No question of conflict of laws was submitted or decided; the Chiles case was not cited; the principal question was whether the statute was a forbidden regulation of interstate commerce. There was no reference to the law of Illinois. The case was treated as one involving the validity of a contract, and, since the law of the state where the contract was made was applied, traditionalists will see nothing of particular interest in the decision. The fact remains that, despite the magical power of characterization to transform a problem, the case presents fundamentally the same question that was decided in Chiles. The law of Michigan was applied to inflict damages for conduct, or neglect, which occurred entirely in Illinois. That state, it is fair to say, has "exclusive legislative power" over conduct within its borders in the same sense that Congress has such power in federal enclaves. Yet no one thought to suggest that the application of Michigan law was an intrusion upon the sovereignty of Illinois; and, assuming that the sender was a Michigan company, the instinct which suppressed any such suggestion was sound, since on that assumption Michigan had a legitimate interest in the application of its law and policy. Moreover, no conflicting policy of another state was suggested.

${ }^{263}$ Granville-Smith v. Granville-Smith, 349 U.S. 1, 7 (1955); cf. Alton v. Alton, 207 F.2d 667 (C.A.3d, 1953). If one of the states should enact a divorce law identical with that of the Virgin Islands, the Supreme Court would be confronted with the same question, in substance, which it had to decide in the Granville-Smith case. No organic act would enable it to avoid deciding the question under the Due Process and Full Faith and Credit clauses, though each state's legislative power is no doubt also limited to "subjects of local application." The dissenting opinion of Judge Hastie in the Alton case soundly suggests that when such a case arises the divorcing state should be constrained, in determining the applicable law, to defer to the state having an interest in the matter. Id., at 684-85. Though his reliance on cases decided on due process grounds seems misplaced in view of the fact that no party to the divorce action was deprived of anything, the full-faith-and-credit cases would lead to the same conclusion.

${ }^{264} 218$ U.S. 406 (1910), aff'g 151 Mich. 425, 115 N.W. 698 (1908). 
The second case cited by Mr. Justice Stone for his conclusion was Western Union Tel.Co. v. Broven..$^{265}$ There the addressee of a telegram dispatched from South Carolina to the District of Columbia sued in South Carolina for nondelivery, claiming damages for mental anguish in accordance with a statute of that state. The defendant pleaded that under the law of the District of Columbia mental anguish is not an element of recoverable damages in the absence of physical injury, and showed that the negligence occurred entirely within the District. Characteristically, Mr. Justice Holmes gave short shrift to the asserted right of South Carolina to apply its law. He did not mention full faith and credit; he did not mention due process, though his statement concerning the "obvious" injustice of imposing a liability greater than that imposed by the law of the place where the negligent conduct occurred is reminiscent of the due process cases. He spoke of South Carolina's attempt to "infringe upon the power of the United States," citing the Chiles case (and the Commercial Milling case!), but did not bother to cite or quote the constitutional provision giving Congress exclusive legislative power in the District. ${ }^{266} \mathrm{At}$ this point, having made no direct reference to any specific provision of the Constitution as the ground of the decision, he remarked that enough had been said to dispose of the case, but added that the South Carolina statute, as applied, was an unconstitutional attempt to regulate interstate commerce. ${ }^{267}$

The first ground stated by Holmes for overturning the South Carolina court's judgment-and, one is tempted to suggest, the real ground, which (for him) made it unnecessary to pinpoint the constitutional basis for the decision-was Holmes's own theory of conflict of laws, with which the state court's decision was in conflict. His statement of it is one of the most remarkable utterances of the Court in connection with its power to review state court decisions:

[I]t is established as the law of this court that when a person recovers in one jurisdiction for a tort committed in another he does so on the ground of an obligation incurred at the place of the tort that accompanies the person of the defendant elsewhere, and that is not only the ground but the measure of the maximum recovery. ${ }^{268}$

In support of this statement he cited his own opinions in the familiar cases of Slater v. Mexican National R.R. ${ }^{269}$ and Cuba R.R. v. Crosby. ${ }^{270}$ Those cases came

265234 U.S. 542 (1914), rev'g 92 S.C. 354, 75 S.E. 542 (1912). See also 85 S.C. 495, 67 S.E. 146 (1909) (same case).

266 U.S. Const. Art. $1, \S 8$, clause 17.

${ }^{267}$ In so doing, he disposed of the Commercial Milling case in what appears to be a quite cavalier fashion; but that problem cannot be pursued here. (Holmes dissented without opinion in that case. See Western Union Tel. Co. v. Commercial Milling Co., 218 U.S. 406, 421 (1910).)

268 Western Union Tel. Co. v. Brown, 234 U.S. 542, 547 (1914).

${ }^{269} 194$ U.S. 120 (1904).

${ }^{270} 222$ U.S. 473 (1912). Since Mr. Justice Holmes speaks of the "obvious" injustice of a different approach, it may be remarked that the decision in the Crosby case was regarded by the New York Judicial Council as a "manifest injustice." State of New York, Ninth Annual Report of the Judicial Council 282 (1943). See Currie, op. cit. supra note 259, at 984-85. 
from lower federal courts, in which the actions had been filed because of diversity of citizenship. They involved no constitutional question. They were decided long before the Erie case, at a time when the federal courts in diversity cases were free to make their own decisions with respect to choice of law. ${ }^{271}$ Yet, in reversing the decision of the highest court of a state, Mr. Justice Holmes says that they represent "the established law of this court." The choice of law which the federal courts were free to make during the reign of Swift $v$. Tyson was imposed upon the state courts by this decision. It is conceivable that $\mathrm{Mr}$. Justice Holmes felt that this result was required by the Due Process Clause or the Full Faith and Credit Clause. His failure to refer to those clauses, however, coupled with his failure to note that what was "established law" in the Court for one purpose might not be so for another, leads one to suspect rather than he was simply so convinced of the cosmic correctness of his obligatio theory that it did not occur to him that the case might be decided on any other basis.

It does not appear whether Mrs. Brown, the plaintiff, was domiciled in, or a resident of, South Carolina; we cannot, therefore, tell whether that state had a legitimate interest in the application of its law.

We come, then, to the question whether these cases are to be treated differently than cases of conflict between states because of the circumstance that federal legislative power is involved on one side. Adequate investigation of the question would proceed far beyond the scope of this paper if consideration were given to the possibly significant differences between the seat of government, military and other enclaves, insular possessions, and incorporated and unincorporated territories. 272 It may be recalled, however, that in one of the leading cases considered, Alaska Packers Association v. Industrial Accident Commission, $^{273}$ there was no suggestion that the analysis was in any way affected by the fact that a territory was involved. Moreover, the act of Congress implementing the Full Faith and Credit Clause extends without distinction to the laws of any state, territory, or possession of the United States. ${ }^{274}$ On the surface, there appears to be no reason why laws designed for the local government of federal territory, whether made directly by Congress or by a local law-making authority, should have any greater standing than the laws of a state for purposes of choice of law. A conflict between state law and such federal law appears to present an entirely different order of problem from that which is presented by a conflict between the law of a state and an act of Congress regulating, say, interstate

${ }^{271}$ Even today, since the cases involved international conflicts, an argument might be made that the choice of law should be a federal question. See Currie, op. cit. supra note 259, at 965 n.2, and authorities cited therein.

272 For an introduction to the complexities, see Granville-Smith v. Granville-Smith, 349 U.S. 1, 4 (1955). Note that while Art. 1, $\S 8$, clause 17, defines the legislative power over the seat of government and over enclaves, a different provision, Art. 4, \$3, clause 2, confers the power to "make all needful Rules and Regulations respecting the Territory or other Property belonging to the United States. ..."

273294 U.S. 532 (1935). 27452 Stat. 947 (1948), 28 U.S.C.A. $\$ 1738$ (1950). 
commerce. Despite intimations to the contrary in Chiles and Brown, the Supremacy Clause ${ }^{275}$ appears to have no application.

The infirmities of these two precedents, plus the modern employment of the interest analysis in Carroll and Watson, would seem to justify the conclusion at this point that there is no longer ground for the pessimism expressed by $\mathrm{Mr}$. Justice Stone as to the status of constitutional control of choice of law in tort cases. A serious question, however, may be raised: Did not the Court, in Hughes v. Fetter ${ }^{276}$ and First National Bank of Chicago v. United Air Lines ${ }^{277}$ turn back the clock, holding that the Full Faith and Credit Clause commands the forum to apply the lex loci delicti in wrongful death cases? In the former case, Mr. Justice Black, for the majority, spoke of " . . . the strong unifying principle embodied in the Full Faith and Credit Clause looking toward maximum enforcement in each state of the obligations or rights created or recognized by the statutes of sister states." 278 It is difficult, as a matter of first impression, to avoid the conclusion that this is a reinstatement of the obligatio theory to constitutional status. ${ }^{279}$ The sounder interpretation, however, is that the Court's famous footnote $10,{ }^{280}$ reserving the possibility that the forum might legitimately apply its own law in adjudicating the merits, means exactly what it says. There is paradox here, but the interpretation suggested can be sustained by an analysis which is beyond the scope of this paper. ${ }^{281}$ Here we can do no more than point out that the interpretation is supported by Wells v. Simonds Abrasive Co. ${ }^{282}$ This decision can be read as a determination that, while Pennsylvania must apply the "substantive" law of Alabama (the locus delicti), it is not required to apply features of the foreign law which have traditionally been regarded as "procedural," despite subtle distinctions which would classify some statutes of limitations as "substantive." The decision is equally consistent, however, with the view that Pennsylvania, as the forum and the principal place of business of the defendant corporation, had a double interest in the application of its shorter limitation period: (1) an interest in safeguarding its judicial processes against claims and evidence rendered unreliable by the passage of time and (2) an interest in safeguarding local people and enterprises against stale claims founded on such unreliable evidence. ${ }^{283}$

275 U.S. Const. Art. 6, clause 2.

276341 U.S. 609 (1951).

277342 U.S. 396 (1952).

${ }^{278} 341$ U.S. 609, 612 (1951).

${ }^{279}$ Cf. New York Life Ins. Co. v. Dodge, 246 U.S. 357 (1918); Western Union Tel. Co. v. Brown, 234 U.S. 542 (1914), rev'g 92 S.C. 354, 75 S.E. 542 (1912).

${ }^{280} 341$ U.S. 609,612 (1951).

281 The problem in these two cases is that of the effect of the Constitution with respect to the "transitory" cause of action and the right of access to the courts of the states. This problem, while closely related to choice of law, is sufficiently different and complex to require separate treatment. See note 90 supra.

282345 U.S. 514 (1952).

${ }^{283}$ Another decision of the Supreme Court involving the effect of the Constitution on choice of law in tort cases is Young v. Masci, 289 U.S. 253 (1933); cf. Scheer v. Rockne Motors Corp., 


\section{Miscellaneous CASEs ${ }^{284}$}

Klaxon Co. v. Stentor Electric Mfg. Co. ${ }^{285}$ contains, in addition to the ruling for which it is famous, a ruling on the constitutionality of a choice of law. The defendant argued, in effect, that it would be pointless to remand the case for a determination of the question whether the choice of New York law as governing the recoverability of interest was in accordance with Delaware conflicts rules, since the Full Faith and Credit Clause, in any event, would require Delaware to apply New York law on the point, New York being the place of contracting. The Court disagreed. Its reason is none too clear:

[The New York statute authorizing or requiring interest] is in no way related to the validity of the contract in suit, but merely to an incidental item of damages, interest, with respect to which courts at the forum have commonly been free to apply their own or some other law as they see fit. Nothing in the Constitution ensures unlimited extra-

68 F.2d 942 (C.A.2d, 1934). The Young case has been mentioned earlier, note 31 supra, as illustrative of the proposition that a question of due process may be raised by a state's unwarranted application of the law of another state. It is also illustrative of the proposition that the Supreme Court will ordinarily uphold application of the law of a state having an interest in the matter, though another state has a contrary interest. By inference, however, it raises the question whether the power of an interested state to apply its law is qualified if the party adversely affected has not in some fashion "subjected" himself to that law. It may be suggested that it is not so limited, but adequate investigation of this question would require extensive inquiry which would be collateral to the main purpose of this paper.

${ }^{284}$ See also National Mutual B. \& I. Ass'n v. Brahan, 193 U.S. 635 (1904), and Western Union Tel. Co. v. Commercial Milling Co., 218 U.S. 405 (1910).

Munday v. Wisconsin Trust Co., 252 U.S. 499 (1920), superficially a routine decision upholding application of the law of the situs, appears to be a case in which the state of the forum and situs was the only state with an interest in the matter.

A number of cases familiar to students of the Constitution and the conflict of laws are not discussed here for various reasons: e.g., Bond v. Hume, 243 U.S. 15 (1917) (a pre-Erie diversity case in which the pertinent expressions are largely dicta); Pennsylvania R.R. v. Hughes, 191 U.S. 477 (1903) (in which the point that an erroneous choice of law by a state court may raise a question under the Due Process Clause or the Full Faith and Credit Clause was not effectively made). Most such cases are excluded because they do not deal with choice of law (e.g., Broderick v. Rosner, 294 U.S. 629 (1935)), or do not deal with choice of law in the limited sense in which that expression is here used:i.e., the foreign law is relevant, if at all, not as furnishing the rule of decision but for some other purpose. See, e.g., Smithsonian Institution v. St. John, 214 U.S. 19 (1909); cf. Hood v. McGehee, 237 U.S. 611 (1915); Olmsted v. Olmsted, 216 U.S. 386 (1910). For further references see the annotations in 73 A.L.R. 897; 74 id. 710 ; 92 id. 932; 100 id. $1143 ; 134$ id. 1472.

Two cases, omitted from treatment here because they do not involve constitutional questions, being pre-Erie diversity cases, are of special interest because they involve another facet of the problem considered in connection with commercial insurance. Here the law of the home state of the insured and the beneficiary provides no ground for recovery, and reliance is placed upon a "nonforfeiture" statute of the state in which the insurance company is incorporated. The Court speaks of the controlling effect of the law of the place of contracting, and construes the statute as applying only to "business transacted" within the state of incorporation. Explicit analysis in terms of the policies and interests of the respective states would lead to the same result. Mutual Life Ins. Co. v. Cohen, 179 U.S. 262 (1900); Mutual Life Ins. Co. v. Hill, 193 U.S. 551 (1904).

${ }^{285} 313$ U.S. 487 (1941). 
territorial recognition of all statutes or of any statute under all circumstances. .. . The full faith and credit clause does not go so far as to compel Delaware to apply $\$ 480$ if such application would interfere with its local policy. ${ }^{286}$

This is susceptible of the interpretation that interest, like the statute of limitations in the Wells case, is a matter so peripheral to the "foreign-created" right that full faith and credit does not require application of the foreign law. It is also consistent, however, with the view that, if the interests of the two states are analyzed, Delaware had a legitimate interest in the application of its law. The effect of that application would be to protect the defendant, a Delaware corporation, from interest before judgment on a claim for unliquidated contract damages. That the Court sensed the existence of such a basis for the application of Delaware law is inferable from the reference to the "local policy" of that state. At all events, the decision is another convincing, though tacit, rejection of the Brandeis fallacy: A Delaware judgment awarding damages without interest would clearly not leave the plaintiff free to pursue its interest claim elsewhere, but would be a disposition on the merits merging that claim. ${ }^{287}$

In view of the numerous cases which have been considered it should be abundantly clear that to cite Kryger $v$. Wilson ${ }^{288}$ for the proposition that an erroneous choice of law by a state court is a mere matter of local common law, raising no constitutional question, is grossly misleading. Taken out of context (as it frequently is) the language of the Court lends color to such a proposition:

The most that the plaintiff in error can say is that the state court made a mistaken application of doctrines of the conflict of laws in deciding that the cancellation of a land contract is governed by the Jaw of the situs instead of the place of making and performance. But that, being purely a question of local common law, is a matter with which this court is not concerned. ${ }^{289}$

Analysis of the case, however, puts this language in a very different light. By a contract made in Minnesota, land situated in North Dakota was to be conveyed upon the payment of the last of several instalments of the purchase price. ${ }^{290}$ Upon default by the purchaser, the vendor gave notice of cancellation in strict accordance with the law of North Dakota, which prohibited cancellation and forfeiture until the lapse of thirty days following notice. After the expiration of the period for redemption the vendor sued in North Dakota to quiet title, and the purchaser sought counter-relief on the ground that notice had not been given in accordance with the Minnesota statute. The North Dakota court up-

$$
{ }^{286} \mathrm{Id} \text {., at } 498 .
$$

${ }^{288} 242$ U.S. 171 (1916), aff'g 29 N.D. 28, 149 N.W. 721 (1914); supplemental opinion rendered 26 N.D. 77,143 N.W. 764 (1913).

${ }^{289} \mathrm{Id}$., at 176.

${ }^{290}$ The defendant, Kryger, was assignee of the original purchaser and was a resident of Minnesota. The plaintiff, Wilson, was transferee of the vendor. His residence, and the connections of the original parties to the contract, are unclear. In the text Kryger and Wilson will be referred to as purchaser and vendor, respectively. 
held the effectiveness of the notice under its own statute and gave judgment quieting title in the vendor. The Supreme Court affirmed.

The most important fact in the case is that the law of Minnesota was substantially the same as that of North Dakota. ${ }^{291}$ Both provided against strict forfeiture of the interest of the purchaser upon default; both provided for notice of cancellation; both provided for a period of thirty days after notice during which the purchaser could come into compliance and reinstate his equity. Moreover, both prescribed the same procedure for giving notice: if the purchaser was a resident. of the state, the notice was to be served in the same way as the process of local courts; if the defendant was not found in the state, it was to be served by publication in a local newspaper. While the prescribed procedure for giving notice is substantially identical in the two statutes, it is evident that the effectiveness of the notice given will be materially affected by the point of view adopted by the vendor when he sets out to comply with the requirement. If he elects to proceed under the law of North Dakota (as the law of the situs) the notice will be given by publication, since the purchaser is a nonresident. If he elects to proceed under the law of Minnesota (as the law of the place of contracting, or the law of the purchaser's residence) the purchaser will be personally served. Whether the election to proceed from the point of view of North Dakota was malign or was made in good faith, it is difficult to see how the Supreme Court could have held that the state court's approval of it violated any constitutional right of the purchaser. Ideally, it might be said that the laws of both states concurred in providing, in substance, for that mode of notice which under the circumstances was the more effectual, and that the vendor should have given notice by personal service in Minnesota since the purchaser was resident there. Given the rigidities of legal reasoning, however, it is probably too much to expect such a holding of the North Dakota court, to say nothing of a decision by the Supreme Court that the Constitution required such a holding. If this case presents a problem in the "conflict of laws" it is one in a very special sense indeed. In fact, the purchaser in this case did not clearly submit a question as to the correctness of the choice of law. He proceeded on the confused theory that the cancellation of the contract by notice was tantamount to a judicial proceeding, in which jurisdiction of his person was prerequisite to a termination of his rights. ${ }^{292}$ In large measure the decision of the Court is designed to refute this fallacy.

A related question was involved in Selover, Bates \& Co. v. Walsh. ${ }^{293}$ The vendor, a resident of Minnesota, entered into a contract with a resident of North Dakota for the instalment sale of land in Colorado. Upon default, the vendor

291 Id., at $174 \mathrm{n} .1$.

${ }^{292}$ Id., at 176-77. Even on this theory, the purchaser overlooked the in rem jurisdiction of the court at the situs. Cf. Rest., Judgments c. 1, Introductory Note (1942). Moreover, the North Dakota court held that the purchaser had not adequately established the Minnesota law. 29 N.D. 28, 34, 149 N.W. 721, 723 (1914).

293226 U.S. 112 (1912), aff'g 109 Minn. 136, 123 N.W. 291 (1909). 
gave written notice of summary cancellation to the purchaser at his residence in North Dakota. The purchaser then sued in Minnesota for damages for breach, relying on the Minnesota nonforfeiture statute, the provisions of which have already been noted. The state court held the statute applicable and the Supreme Court affirmed, both relying on the fact that the contract was made and to be performed in Minnesota. In Kryger $v$. Wilson this earlier decision was distinguished as involving a personal action for damages rather than an action to quiet title. ${ }^{294} \mathrm{~A}$ better distinction, I believe, is suggested by the following analysis: So far as appears, Minnesota had no interest in the application of its nonforfeiture policy in the Walsh case. That policy was for the protection of purchasers, and the purchaser, being a resident of North Dakota, was not within the ambit of Minnesota's governmental concern. Nor did Minnesota have a symbolic basis for the assertion of an interest in protecting purchasers wherever located, as might be suggested if the land had been located in the state. The statute, however, was not so pointedly local that its application was inappropriate in the absence of pleading and proof (or other appropriate invocation) of the proper foreign law; ${ }^{295}$ and, so far as appears, the vendor made no showing that strict forfeiture was permitted by the law of North Dakota or that of Colorado. ${ }^{296} \mathrm{We}$ have already seen that a state's choice of law cannot be attacked as a denial of due process or full faith and credit unless the law which should properly be applied is duly established. ${ }^{297}$ This case appears, therefore, to hold no more than that no constitutional provision was violated by Minnesota's application of its own law in the absence of any showing of the proper foreign law..$^{298}$

\section{ConcLuSION}

The basic thesis of this paper-that a state court's choice of law will be upset under the Full Faith and Credit Clause or the Due Process Clause only when the state whose law is applied has no legitimate interest in its application-seems amply supported by this review of the precedents. Eighteen of the cases considered either specifically support the analysis in terms of governmental interest or are consistent with it. ${ }^{299}$ Nine of the cases which might be cited against it are either

294242 U.S. 171, 177 (1916).

${ }^{295}$ See Currie, On the Displacement of the Law of the Forum, 58 Col. L. Rev. 964 (1958).

${ }^{296}$ Selover, Bates \& Co. v. Walsh, 57 L.Ed. 146, 150 (1912).

${ }^{297}$ See note 259 supra.

${ }^{298}$ After arguing that the Minnesota statute did not apply, the vendor proceeded to argue that under the (general?) common law the parties may contract for strict forfeiture. See Selover, Bates \& Co. v. Walsh, 226 U.S. 112, 114 (1912). This suggests the question: Can the defect of foreign law be cured, for purposes of making the constitutional objection, by reliance on the presumption that the law of a sister state is the same as the common law of the forum? Whatever utility that presumption may have in other contexts, see Currie, op. cit. supra note 295, at $977-81$, it surely ought not to furnish a substitute for a showing of the actual basis of rights for which constitutional protection is claimed.

${ }^{299}$ Alaska Packers Association v. Industrial Accident Commission, 294 U.S. 532 (1935); Pacific Employers Ins. Co. v. Industrial Accident Commission, 306 U.S. 493 (1939); Carroll v. Lanza, 349 U.S. 408 (1955); New York Life Ins. Co. v. Cravens, 178 U.S. 389 (1900); New 
discredited or distinguishable ${ }^{300}$ Only four, or at the most six, of the cases are inconsistent with the thesis, either because of the Court's adherence to conceptualism or because of its willingness to "weigh" and choose between the conflicting interests of the states; and three of these relate to fraternal insurance-a peculiar institution with respect to which the Court's attitude is apparently changing. ${ }^{301}$

As has already been observed, the fact that the Court has tended, especially in recent years, to approach these problems in terms of state interests is widely understood and accepted. ${ }^{302}$ The matter which needs to be clarified is the role of the Court in cases in which each of the states involved has a legitimate interest in the application of its law. The Court has often spoken as if its function were to evaluate the respective interests and choose between them, and commentators have strongly tended to agree. ${ }^{303} \mathrm{It}$ is not always clear just what this function would involve: whether it implies a judgment as to the relative merits of the conflicting policies, or a comparative appraisal of the number, character, and

York Life Ins. Co. v. Head, 234 U.S. 149 (1914); American Fire Ins. Co. v. King Lumber Co., 250 U.S. 2 (1919); Home Ins. Co. v. Dick, 281 U.S. 397 (1930); John Hancock Mutual Life Ins. Co. v. Yates, 299 U.S. 178 (1936); Griffin v. McCoach, 313 U.S. 498 (1941); Watson v. Employers Liability Assurance Corp., 348 U.S. 66 (1954); Hoopeston Canning Co. v. Cullen, 381 U.S. 313 (1943); National Mutual B. \& L. Ass'n v. Brahan, 193 U.S. 635 (1904).

Equitable Life Assurance Society v. Clements, 140 U.S. 226 (1891); Orient Ins. Co. v. Daggs, 172 U.S. 557 (1899); Aetna Life Ins. Co. v. Dunken, 266 U.S. 389 (1924); Western Union Tel. Co. v. Commercial Milling Co., 218 U.S. 406 (1910); Wells v. Simonds Abrasive Co., 345 U.S. 514 (1953); Klaxon Co. v. Stentor Electric Mfg. Co., 313 U.S. 487 (1941).

${ }^{300}$ Bradford Electric Light Co. v. Clapper, 286 U.S. 145 (1932); New York Life Ins. Co. v. Dodge, 246 U.S. 357 (1918); Allgeyer v. Louisiana, 165 U.S. 578 (1897); Sovereign Camp of the Woodmen of the World v. Bolin, 305 U.S. 66 (1938); Western Union Tel. Co. v. Chiles, 214 U.S. 274 (1909); Hughes v. Fetter, 341 U.S. 609 (1951); First National Bank of Chicago v. United Air Lines, 342 U.S. 396 (1952); Kryger v. Wilson, 242 U.S. 171 (1916); Selover, Bates \& Co. v. Walsh, 226 U.S. 112 (1912).

${ }^{301}$ Hartford Accident \& Indemnity Co. v. Delta \& Pine Land Co., 292 U.S. 143 (1934); Royal Arcanum v. Green, 237 U.S. 531 (1915); Modern Woodmen of America v. Mixer, 267 U.S. 544 (1925); Order of United Commercial Travelers v. Wolfe, 331 U.S. 586 (1947). See also Mutual Life Ins. Co. v. Liebing, 259 U.S. 209 (1922); Western Union Tel. Co. v. Brown, 234 U.S. 542 (1914). As to Young v. Masci, see note 283 supra.

${ }^{302}$ Note 11 supra.

${ }^{303}$ Freund, Chief Justice Stone and the Conflict of Laws, 59 Harv. L. Rev. 1210 (1946); Cheatham, Federal Control of Conflict of Laws, 6 Vand. L. Rev. 581 (1953), AALS Readings 255; Jackson, Full Faith and Credit-the Lawyer's Clause of the Constitution, 45 Col. L. Rev. 1 (1945), AALS Readings 229; A Factual Approach to the Constitutional Law Aspects of the Conflict of Laws, 35 Col. L. Rev. 751 (1935); Full Faith and Credit to Statutes, 45 Yale L. J. 339 (1935); Full Faith and Credit As Applied to Statutes, 51 Mich. L. Rev. 26 ' (1952); Overton, State Decisions in Conflict of Laws and Review by the United States Supreme Court under the Due-Process Clause, 22 Ore. L. Rev. 109 (1943).

A recent article in which the analysis in terms of governmental interests is clearly appreciated nevertheless maintains that the Court should assume a more active role in the supervision of state court decisions, striving for uniformity through evaluation of the competing state interests. Speidel, Extraterritorial Assertion of the Direct Action Statute, 53 Nw. U. I. Rev. 179, 194-95, 224-25 (1958). 
significance of the relations of the state to the case which are putforward as the basis for its interest. Nor is it clear that these alternatives are significantly different.

It is clear that the Court has assumed to perform such a function only rarely, and one of the theses of this paper is that it should do so even more rarely, if at all. The reason is that choice between the competing interests of coordinate states is a political function of a high order, which ought not, in a democracy, to be committed to the judiciary; that the Court is not equipped to perform such a function; and that the Constitution specifically confers that function upon Congress.

This is likely to be a controversial thesis, and I hope I can state it with moderation. For one hundred and seventy years Congress has made no use of its power to prescribe the effect in one state of the laws of another; it is not likely to exercise that power so long as traditional views as to the nature of conflict-of-laws questions prevail. In such a vacuum, conceptions of the judicial function are likely to expand. My own conception of that function is not, I believe, unduly restrictive; I should be among the last to support the outmoded fiction that a court can do no more than apply pre-existing principles in the adjudication of a controversy. The function of the Supreme Court, in particular, is, of course, creative and dynamic. Its function as arbiter between the nation and the states is a delicate one, calling for the use of statesmanlike discretion and entailing political consequences of great magnitude. Yet in the performance of that function definite lines are laid out for the Court's guidance. It is never called upon to "weigh" the national interest against that of a state, but only to determine the policies and interests involved. In case of conflict, there is no question as to which interest must prevail: that question is answered by the Supremacy Clause. But not even the Full Faith and Credit Clause furnishes similar guidance for preferring the interest of one state over that of another.

This is the Court which for nearly a century supervised the development of a body of general federal common law. ${ }^{304}$ This is the Court which only recently inferred and accepted a Congressional mandate that it supervise the "fashioning" of a body of substantive federal law for application to controversies arising under collective-bargaining agreements. ${ }^{305}$ This is the Court which, in the exercise of its original jurisdiction over controversies between two or more states, ${ }^{306}$ sits in judgment not merely on the "interests" of the states as they are invoked in private litigation but on the rights and duties of the states as political entities -and this without specific principles of law to guide it. This it does, however, as a matter of sheer riecessity. Unless the jurisdiction is to be abdicated, the case (1938).

${ }^{304}$ From Swift v. Tyson, 16 Pet. (U.S.) 1 (1842), to Erie R. Co. v. Tompkins, 304 U.S. 64

${ }^{305}$ Textile Workers Union of Amer. v. Lincoln Mills, 353 U.S. 448 (1957). "The range of judicial inventiveness will be determined by the nature of the problem." Id., at 457 .

${ }^{306}$ U.S. Const. Art. $3, \$ 2$. 
must be decided. While Congress probably has power, under the Necessary and Proper Clause, ${ }^{307}$ to prescribe rules of decision for controversies between states, the Court cannot wait for such Congressional action, but must find its rules of decision where it can. No such necessity dictates the development of criteria for choice between the interests of two or more states in private litigation, and the constitutional power of Congress to develop such criteria is express, not implied. In the private cases with which we are concerned, a controversy has been adjudicated by the highest court of a state. If that state has an interest in the application of its law, the fact that another state has a contrary interest does not necessitate a resolution of that conflict. The Court has only to leave undisturbed the state court's application of its own law-as the Court has actually done, with few exceptions. The controversy between the parties does not go undecided. If the impairmen't of the interest of the other state is undesirable from the national stan'dpoint, the Court can wait for Congress to determine that fact.

I am not disposed to condemn the Court for "usurpation" because it has on rare occasions undertaken to choose between conflicting interests of the states without guidance from Congress. In some instances, Congressional inaction in the face of grave social problems has no doubt seemed frustrating beyond endurance, and, especially since the political nature of the function of weighing competing state interests has not alwayys been clearly apparent, it is understandable that the Court should have undertaken to do what it could to solve the problem. This is my interpretation of the decision in the first Williams case. ${ }^{308}$ While that case involved full faith and credit to a judgment, it is analogous to the problem of full faith and credit to the laws of a state because with respect to the matter in question the act of Congress provided no guidance. ${ }^{309}$ Other situations may arise from time to time in which the temptation to intervene in the absence of Congressional action will be similarly great, and I shall not be unduly shocked if the Court succumbs. Its decision will be better informed, however, if the nature of the function it is undertaking is clearly understood by the Court, and if the issue is not clouded by "preconceptions that purport to compel the decision, but in fact do not." 310 Above all, perhaps, my concern is that we shall not delude ourselves with the supposition that we can develop, as a branch of jurisprudence, a science or system of conflict of laws which will either rationalize or guide the decisions of the Court in such cases.

${ }^{307}$ U.S. Const. Art. 1, $\S 8$, clause 18. Cf. Detroit Trust Co. v. The Thomas Barlum, 293 U.S. 21 (1934).

${ }^{308}$ Williams v. North Carolina, 317 U.S. 287 (1942). The fact that the Court's intervention has not contributed greatly to removing the confusion concerning divorce recognition is testimony to the Court's limitations as an agency for the resolution of such conflicts.

${ }^{309}$ The direction that the Nevada decree be given such faith and credit as it has by law or usage in the state from which it is taken is not helpful in a criminal prosecution in North Carolina for bigamous cohabitation. There is, and can be, no law in Nevada as to the effect of its decree upon a criminal prosecution by another state. See, Stranger Attack on Sister-State Decrees of Divorce, 24 U. of Chi. L. Rev. 376 (1957).

${ }^{310}$ Traynor, Law and Social Change in a Democratic Society, [1956] III. L. Forum 230, 234. 
The fraternal insurance cases should furnish ample support for this position. The character of the decisions which the Court has made in this area has been obscured by talk of the "indivisible unity" 311 of the organization, of the "complex and abiding relation" 312 between the organization and its members, and of the ineluctable logic of the proposition that the law of the state of incorporation alone must govern. ${ }^{313}$ Brushing aside such conceptualism, we may find apparent justification for the decision in the social and economic circumstances surrounding fraternal organizations in the early period of their development. The Court apparently reasoned that such societies served a useful purpose; that they could not very well operate without uniformity in the law applicable to their obligations to members; that they were benevolent, not being operated for profit, and their management was subject to the control of members through the representative form of government; and that state policies for the protection of residents dealing with commercial companies were not necessary for the protection of members of such organizations. Assume that, as has been suggested, ${ }^{314}$ these conditions have changed: that the need for uniformity in such matters is not critical; that such societies have grown large and impersonal, that a distinct managerial interest has emerged, that the member has little voice in the selection of managerial personnel and in managerial policies; that, in general, such societies are difficult to distinguish from commercial mutual companies. How is the Court to keep abreast of such developments? How is it to explain its change of position? How are lawyers to keep up with such developments, plan transactions, advise clients, and prepare cases for trial? Where is the certainty and predictability which the jurisprudence of conflict of laws strives to provide? And how are law students to be trained to understand and participate in the Court's processes?

Another example, taken from an area in which the Supreme Court has not yet acted, will illustrate both (1) the danger of the present situation, in which the Court's intervention is likely to be justified by plausible appeals to vacant and self-serving concepts, and (2) the inherent limitations on the Court's capacity to resolve such problems. An enterprise incorporated in one state may do business in many states. Most of these will have laws, designed primarily for the protection of creditors, limiting the funds from which dividends may be declared. It is understandable that those who advise boards of directors on the legality of dividend declarations should desire that a single law should be applicable-preferably that of the corporate domicile, so that the incorporators can at the outset choose the law which is to their liking. Such a consummation can be attained only by abrogating the interest of other states in protecting local people who deal, locally and otherwise, with the corporation. This fact does not deter the 311 Royal Arcanum v. Green, 237 U.S. 531, 542 (1915); Modern Woodmen of America v. Mixer, 267 U.S. 544, 551 (1925).

${ }^{312}$ Sovereign Camp of the Woodmen of the World v. Bolin, 305 U.S. 66, 75 (1938); Modern Woodmen of America v. Mixer, 267 U.S. 544, 551 (1925).

${ }^{313}$ Note 205 supra.

${ }^{314}$ See discussion at note 250 supra. 
advocates of uniformity. I know of no instance of their having appealed to Congress for a resolution of these conflicting interests, as they might legitimately do. Instead, they call upon the Supreme Court to discharge its duty to designate the state whose law can alone govern. ${ }^{315}$ And by what standards is the Court to act in the discharge of this "duty"?

[F]or convenience and, it is submitted, as a necessity the determination of a dividend's legality must be made by a single law [the law of the state of incorporation]. It would be impracticable and illogical to have a single dividend declared valid in one state and invalid in another. ${ }^{316}$

Moreover, we are told that to concede the interest of another state in the application of its different law for the protection of local creditors involves an " inherent logical inconsistency' - the impossibility of having more than one state determine the legality of certain corporate activity. ... ${ }^{9317}$ Finally, we are told that ". . . the Court does have a duty to choose the applicable law in certain circumstances so that one state is not given the power to control activities in which it does not have the paramount interest."'318

The problem is relatively simple. The Court need not be unduly concerned about the delicacy of subordinating the interest of one state to that of another. Corporation counsel and scholars will explain to the Court that it is inconvenient for a corporation, in arranging its affairs, to take account of the laws and policies which various states have enacted for the protection of their residents; they will supply the Court with catch-words and with logical arguments in terrorem, and will invite the Court to expand indefinitely the principles of natural law announced in the fraternal insurance cases. They will explain that the interest of a state in protecting resident creditors in their dealings with a foreign corporation is trivial, or "minimal." With such assistance, how can the Court fail to see that the interest of the state of incorporation in facilitating the transaction of corporate affairs in easy and uncomplicated fashion is "paramount"?

The Court should have but one response to such special pleading: it should simply refer the pleader to Congress. ${ }^{319}$ This is not to say that the Court cannot

${ }^{315}$ See Coleman, Corporate Dividends and the Conflict of Laws, 63 Harv. L. Rev. 433 (1950), partially reprinted in AALS Readings at 275. "In such instances the Supreme Court as the final arbiter in our federated system does not discharge its task by a mere discovery of minimum contacts; it must go further and make the choice of the particular place which can take the fund to the exclusion of the other possible claimants." Id., at 462.

${ }^{316}$ Id., at 439 (italics added). It is with some consternation that one finds Professor Harper making a similar argument with reference to fraternal insurance as late as 1947: "[A]ny other rule than that applied in the Royal Arcanum case would constitute a death sentence to fraternal benefit societies. Indeed, it is clear that the problem in Royal A rcanum is one so intimately connected with the state of incorporation that it is inconceivable that the law of any other state should control it." Harper, The Supreme Court and the Conflict of Laws, 47 Col. L. Rev. 883, 898 (1947).

${ }^{317}$ Coleman, op. cit. supra note 315 , at 460-61. (Italics added.)

${ }^{318} \mathrm{Id}$., at 467 . (Italics added.)

${ }^{319}$ A somewhat similar problem was examined as early as 1910 in Hohfeld, The Individual Liability of Stockholders and the Conflict of Laws, 9 Col. I. Rev. 285, 492 (1909), 10 id. 283, 
inquire at all into the validity of the asserted interests. Certainly it can conclude that the asserted state policy has no demonstrable existence. ${ }^{320}$ Similarly, it can determine that the asserted basis for an interest in the application of a policy is too technical or attenuated to be of constitutional significance. ${ }^{321}$ Beyond this, for the Court to label one interest paramount and the other minimal, or one major and the other minor, is simply to legislate-as one strong voice, crying in the wilderness, told us a good many years ago. ${ }^{322}$

This way of looking at the matter provides answers for two questions which have been considerably mooted in the past: (1) Is the Full Faith and Credit Clause self-executing ${ }^{323}$ and (2) If the Full Faith and Credit Clause is construed as establishing a comprehensive constitutional framework for the solution of problems of conflict of laws will not the Supreme Court be inundated by a deluge of appeals and petitions for certiorari? ${ }^{324}$ To say that a constitutional provision is self-executing is simply to say that it can be applied by the courts without legislative implementation. The Full Faith and Credit Clause is selfexecuting to the extent that it can be applied by the courts in the absence of implementing legislation-i.e., where it is clear that a particular state's law should be applied, because only that state has an interest. It is not self-executing where legislative implementation is required, as it is when the interests of two or more states are in conflict. As to the effect on the business of the Court of recognition of the comprehensive function of the Full Faith and Credit Clause with respect to conflict of laws, the answer appears clearly to be that the caseload should be somewhat less than it has formerly been. The Court would still be called upon, as it has in the past, to strike down occasional applications of state law unwarranted by any interest of the state concerned. It would no longer be enticed into frustrating and time-consuming efforts to deal with the "refractory" 325 problem of "weighing" competing state interests.

The significance of this analysis for conflict of laws in general lies primarily in the fact that, if "weighing" the conflicting interests of several states is not a proper function for the United States Supreme Court, it follows a fortiori that this is not a proper function for the state courts themselves. The Supreme Court is a national court; such a function is inappropriate for it only because of the inherent limitations on the capacity of a judicial establishment, and because of

520 (1910). Although the discussion is deeply affected by the conceptualism of its time, it is scholarly and responsible and recognizes the conflicting governmental interests involved.

${ }^{320}$ John Hancock Mut. Life Ins. Co. v. Yates, note 158 supra; cf. Hughes v. Fetter, 341 U S. 609 (1951).

${ }^{201}$ Note 156 supra. 322 Ross, op. cit. supra note 26 , at $173,181$.

s23 Ibid.; Moore \& Oglebay, oD. cit. supra note 11, at 606; Langmaid, op. cit. supra note 11, at 388 et seq.

324 Dodd, op. cit. supra note 11, at 560; Freund, op. cit. supra note 11, at 1234; Reese, op. cit. supra note 88; Jackson, op. cit. supra note 11, AALS Readings at 229.

${ }^{325}$ Frankfurter, J., concurring, in Watson v. Employers Liability Assurance Corp., 348 U.S. 66,78 (1954). 
the principle of separation of powers. When and if that Court assumes to perform such a function it is not in the position of having to set at naught an interest of the government which created it, but only of subordinating the interest of one of the states which comprise the Union to that of another. A state court, on the other hand, is normally in the position of choosing whether the interest of its own sovereign shall prevail or be subordinated to that of a coordinate sovereign. ${ }^{326}$ To state the proposition as moderately as possible, a court should decide that the interest of the state whose creature it is shall be subordinated to that of a coordinate state only in rare cases and for compelling reasons. One is tempted to state the proposition more strongly, because the traditional system of conflict of laws counsels the courts to sacrifice the interests of their own states mechanically and heedlessly, without consideration of the policies and interests involved; and there is need to dispel the paralyzing influence of that system. Assuming, however, that the obfuscations of the system were cleared away, there might conceivably be situations in which a court might rationally conclude that securing a specific, limited interest of its own state is less important than advancement of the general interest of the state, and of the states generally, in maintaining a reasonably stable and civilized general legal order. ${ }^{327}$ This, of course, is parallel to statements of the classical objectives of a system of conflict of laws, but I conceive it as having a much more limited sphere of operation. The traditional system largely ignores governmental interests. It is not enough to suggest that such interests be brought to the fore for consideration if we still counsel that, after they have been duly considered, the highest priority is still to be given to nebulous and altruistic ideals which ignore the facts of the real political world. At the least, before subordinating a specific interest of its own state, a court should appraise realistically the likelihood that its action will result in the desired condition of uniformity and stability, and should carefully calculate the price which it is committing the state to pay for the expected result. Even so, I find it difficult to escape the conclusion that such an appraisal and calculation is essentially a political function, and that neither the science of jurisprudence nor its offspring, the conflict of laws, can afford much guidance for its performance.

The matter may be clarified by comparing the situation of the state court in such a case with that of the Supreme Court. When the case reaches the Supreme Court the policy of the state has been authoritatively declared and its interest asserted; subject to qualifications which have been noted, the Supreme Court is bound by these determinations. The state court, on the other hand, has a degree

${ }^{326}$ This passes over the situation in which the forum has no interest in the matter, and is called upon to choose between the interests of two or more other states-a quite impossible position in the absence of congressional guidance. See Currie, Married Women's Contracts: A Study in Conflict-of-Laws Method, 25 U. of Chi. L. Rev. 227, 262 (1958).

${ }^{327}$ According Full Faith and Credit to Foreign Modifable Alimony Decrees, 26 U. of Chi. L. Rev. 136 (1958). 
of latitude in determining what the state's policy is, and where its interests lie. Enlightened and restrained interpretation in such a situation can contribute to the minimization of conflicts problems and to the advancement of a stable legal order. ${ }^{328}$ While it must not be assumed that such an approach would eliminate conflicts of interest, the area in which it might be effective is not inconsiderable. 329

These considerations provide an answer for another question which has been much discussed in the literature of this subject: Assuming that the Full Faith and Credit Clause and the Due Process Clause establish certain requirements for the choice of law, how much room remains in which the states are free to make their own determinations in such matters? ? $^{330}$ The suggested answer is that, given a definition of the policies of the states and of their interests in the application of those policies, the Constitution and the Supreme Court control the choice of law to the full extent that the jurisprudence of conflict of laws rationally makes such control possible-i.e., to the extent that it can be said that one state has a legitimate interest and the other has none. Beyond this the Court cannot go; jurisprudence provides no help. But if this is true for the Supreme Court, it is true also for the courts of the states. Apart from the constitutional alternatives which have been discussed, there are just two courses open to a state court: (1) By exercising restraint and moderation beyond what is required by the Constitution, it can, by the process of construction and interpretation, determine the policies and interests of its own state in such a way as to avoid conflict, ${ }^{331}$ or (2) it can subordinate the policy of its own state without violating the federal Constitution. The first course involves a use of judicial discretion which is not peculiar to conflict of laws. The second involves an act of political choice. It is in the area in which the Constitution does not control the choice of law that the jurisprudence of conflict of laws is currently supposed to make its contribution; it is in precisely this area that it has no contribution to make. $^{332}$

If this analysis is sound, there is a further powerful reason why the Supreme Court should not undertáke the role of arbiter of conflicting state interests. If

${ }^{228}$ Ct. Kinney Loan \& Finance Co. v. Sumner, 159 Neb. 57, 65 N.W.2d 240 (1954), with Personal Finance Co. v. Gilinsky Fruit Co., 127 Neb. 450, 255 N.W. 558 (1934).

320 The whole problem of formalities might thus be clarified. See Model Execution of Wills Act \$7, 9A U.L.A. 347 (1957); cf. Fuller, Consideration and Form, 41 Col. L. Rev. 799 (1941).

${ }^{330}$ Hilpert and Cooley, op. cit. supra note 11 , at 43 ; cf. Reese, op. cit. supra note 88.

${ }^{331}$ An excellent illustration (on the national level) is furnished by the Supreme Court's recent interpretation of the Jones Act as not applying to an injury occurring in American territorial waters where all other relevant factors are associated with a foreign country. Romero v. International Terminal Operating Co., 79 S.Ct. 468, 485 (1959).

${ }^{332}$ It should be remembered that we are here dealing not with the whole field of conflict of laws, nor even with the whole range of cases which are customarily treated as "choice of law" problems, but only with cases in which the search for the appropriate rule of decision potentially involves a conflict of state interests. See note 2 supra. 
the highest court of a state, having determined that the state has an interest in the application of its law to the case at hand, can reasonably be expected to do no more than uphold that interest by applying its own law, it would be anomalous for the Supreme Court to reverse the judgmen't of the state court because it has taken that reasonable course. Even if it were conceded that the Supreme Court, as a national tribunal, might transcend the usual limitations of the judicial process and appraise the relative merits of state interests from a national point of view, a state court cannot reasonably be expected to do so; and where novel questions are concerned it would be necessary, as a matter of course, for that Court to reverse judgments for which, at the state level, there was no reasonable alternative. That this has been done in the past, as in the fraternal insurance cases, is no excuse for doing it in the future, as in cases involving the legality of corporate dividends. ${ }^{333}$

$A$ priori, it may seem that, in a federal union where power exists to resolve such conflicts of state interests, it is unfortunate that they should be allowed to remain unresolved, and that the outcome of private litigation should therefore continue to depend to so large an extent on the place where the action is brought. That, however, is not a judgment to be made in the large. With respect to any particular question within the field of workmen's compensation, or commercial insurance, or fraternal insurance, or torts, or corporate affairs, the question should be whether the existing situation, in which each state is free to advance its own legitimate interests by applying its own law, is preferable to a particular proposed alternative. In any event, proposed alternatives should be addressed to Congress, ${ }^{334}$ and we should rid ourselves of the delusion that courts and legal scholars can devise solutions by deduction from a set of axioms pertaining to territorial jurisdiction, or indeed by any other reliance on the resources of jurisprudence alone.

${ }^{333}$ Another question relevant in this connection concerns the function of the federal courts with respect to choice of law in diversity cases. There is strong temptation to urge that, contrary to the settlement of this question in the Klaxon and Griffin cases, those courts should be free to make a choice, independent of state conflicts rules, of the applicable state law. As national courts, they would be free from the embarrassment of subordinating an interest of the sovereign which created them; the anomaly of reversing a state court decision for which there is no reasonable alternative would not be present. I have in the past argued for freedom for the federal courts to make their own choice of law, emphasizing the desirability of that freedom in cases like Griffin v. McCoach. See Currie, Change of Venue and the Conflict of Laws, $22 \mathrm{U}$. of Chi. L. Rev. 405, 491 et seq. (1955). That position assumes that it is possible for the federal courts on rational grounds to develop criteria for choosing between the competing legitimate interests of different states. In the light of the analysis in the text, however, it now seems clear that the federal court is in no better position than a state court to perform that essentially political function. See Currie, Married Women's Contracts; A Study in Conflict-of-Laws Method, 25 U. of Chi. L. Rev. 227, 266 (1958). See Jackson, J., concurring, in McGrath v. Kristensen, 340 U.S. 162, 176 (1950).

${ }^{334}$ In view of the appalling suggestions that are sometimes made when legislative intervention in matters of conflict of laws is contemplated, e.g., Stimson, Simplifying the Conflict of Laws: A Bill Proposed for Enactment by the Congress, 36 A.B.A. J. 1003 (1950); Sumner, Choice of Law Governing Survival of Actions, 9 Hastings L. J. 128, 143 (1958), one mentions Congressional action with grave misgivings, and only because of faith that reason and industry may ultimately prevail even in the field of conflict of laws. 